\author{
Monograph \\ urn:lsid:zoobank.org:pub:510A70C2-01F5-4C6E-855D-EFE140B45664
}

\title{
Revision of the Eurybrachidae XIV. The Australian genera Olonia Stål, 1862 and Stalobrachys gen. nov. (Hemiptera: Fulgoromorpha)
}

\author{
Jérôme CONSTANT \\ Royal Belgian Institute of Natural Sciences, O.D. Phylogeny and Taxonomy, \\ Entomology, Vautier Street 29, B-1000 Brussels, Belgium. \\ E-mail: jerome.constant@naturalsciences.be \\ urn:1sid:zoobank.org:author:6E6072A1-9415-4C8D-8E60-2504444DB290
}

\begin{abstract}
The Australian genus of Eurybrachidae Stål, 1862 (Hemiptera, Fulgoromorpha) Olonia Stål, 1862 is redescribed and reviewed. Seven new species are described: O. bourgoini sp. nov. (N Queensland, Chillagoe), O. danielsi sp. nov. (N Queensland, Cape York Peninsula), O. guillaumei sp. nov. (N Queensland), O. hochae sp. nov. (N Queensland, Undara), O. monteithi sp. nov. (Queensland), O. rylandae sp. nov. (N Queensland, Chillagoe) and O. soulierae sp. nov. (Queensland). Platybrachys nobilis (Stål, 1863) is transferred to Olonia and the new combination Olonia nobilis (Stål, 1863) comb. nov., is proposed. Olonia ornata Lallemand, 1928 and O. apicalis (Walker, 1851) are removed from Olonia and transferred to Platybrachys Stål, 1859 and Maeniana Metcalf, 1952, respectively. Hence, the new combinations Platybrachys ornata (Lallemand, 1928) comb. nov. and Maeniana apicalis (Walker, 1851) comb. nov. are proposed. The new genus Stalobrachys gen. nov. is described to accommodate Olonia alboapicata Jacobi, 1928 and the new combination S. alboapicata (Jacobi, 1928) gen. et comb. nov. is proposed. The male genitalia are illustrated and photographs of habitus, a distribution map, biological data and an identification key are provided. The genus Olonia currently contains twelve species and the genus Stalobrachys gen. nov. has one species.
\end{abstract}

Keywords. Planthopper, Ipomoea, Queensland.

Constant J. 2018. Revision of the Eurybrachidae XIV. The Australian genera Olonia Stål, 1862 and Stalobrachys gen. nov. (Hemiptera: Fulgoromorpha). European Journal of Taxonomy 486: 1-97.

https://doi.org/10.5852/ejt.2018.486

\section{Introduction}

Eurybrachidae is a small family of planthoppers (Fulgoromorpha Evans, 1946) with 41 genera and 193 species, representing only $1.7 \%$ of the genera and $1.4 \%$ of the species of Fulgoromorpha. The family is restricted to the Old World and is distributed in the Afrotropical, Oriental and Australasian regions, with some species present in the southeasternmost part of the Palaearctic region in China; it is not recorded from Madagascar or Taiwan (Metcalf 1956; Bourgoin 2018). Eurybrachidae represent a characteristic 
component of the planthopper fauna of Australia, with 14 genera and 48 species which all belong to the tribe Platybrachini Schmidt, 1908 of the subfamily Platybrachinae Schmidt, 1908. This subfamily counts 20 genera distributed in the Afrotropical, Oriental and Australasian regions. A single genus, Ancyra White, 1845, is included in the tribe Ancyrini Schmidt, 1908 and is the only representative of the Platybrachinae in the Oriental region. All the other 19 genera of Platybrachinae belong to the tribe Platybrachini and are endemic either to the Afrotropical (5 genera) or to the Australasian region (Metcalf 1956; Fennah 1964; Bourgoin 2018). The Australian Eurybrachidae are known to feed on trees and shrubs belonging to two families, Myrtaceae (Eucalyptus spp.) and Fabaceae (Acacia spp.); however, the host plants are still very poorly documented and remain unknown for most of the species (Constant 2006a, 2006b, 2008b; Bourgoin 2018). When I began the revision of Eurybrachidae (Constant 2004), it appeared necessary to redefine and review all existing genera. The genus Olonia was rapidly recognized as problematic, being poorly defined and containing species erroneously placed in it (Constant 2006b). The scrutiny of the types of all species placed in Olonia and putatively closely related genera (e.g., Platybrachys Stål, 1859, Lyncilia Stål, 1863, Maeniana Metcalf, 1952), together with the study of numerous unidentified specimens, now allow the completion of a comprehensive revision of the genus Olonia as the fourteenth part of the ongoing revision of the family.

The present paper aims to fully revise the taxonomy of Olonia, to describe seven new species, to fix the status of Lyncilia nobilis Stål, 1863, Olonia ornata Lallemand, 1928 and O. apicalis (Walker, 1851), and to describe a new genus, Stalobrachys gen. nov., to include Olonia alboapicata Jacobi, 1928, together with providing complete illustrations of all the species, an identification key, distribution maps and biological data.

\section{Material and methods}

The types of all described species have been studied and as much material as possible has been examined. The genitalia of all the males have been checked.

The genitalia were extracted after boiling the abdomen for some minutes in a $10 \%$ solution of potassium hydroxide $(\mathrm{KOH})$ at about $100^{\circ} \mathrm{C}$. Some drops of saturated alcoholic Chlorazol black solution were added for contrasting (Carayon 1969). The pygofer was separated from the abdomen and the aedeagus dissected with a needle blade for examination in 70\% ethanol. All resulting fragments were then placed in glycerine for preservation in a tube attached to the pin of the corresponding specimen.

For routine identification, the abdomen was removed and the genitalia examined directly. In this case, the dry abdomen was placed in a gelatin capsule or glued on cardboard, pinned under the specimen.

Posterior wings were also mounted for a large number of specimens; they have been glued on white cardboard or transparent plastic rectangles and then pinned under the specimen.

The description of the female genitalia follows Bourgoin (1993) with some additions from the studies of Soulier-Perkins (1997) and Soulier-Perkins \& Bourgoin (1998) on the family Lophopidae; the description of the wing venation follows Bourgoin et al. (2015).

The measurements were taken as in Constant (2004) and the following abbreviations are used:

$\mathrm{BF}=$ maximum breadth of the frons

$\mathrm{BT}=$ maximum breadth of the thorax

$\mathrm{BTg}=$ maximum breadth of the tegmen 
$\mathrm{BV}=$ maximum breadth of the vertex

$\mathrm{BW}=$ maximum breadth of the posterior wing

$\mathrm{LF}=$ length of the frons in midline

$\mathrm{LM}=$ length of the mesonotum in midline

$\mathrm{LP}=$ length of the pronotum in midline

$\mathrm{LT}=$ total length from anterior margin of vertex to apex of tegmina

$\mathrm{LTg}=$ maximum length of the tegmen

$\mathrm{LV}=$ length of the vertex in midline

$\mathrm{LW}=$ maximum length of the posterior wing

The metatibiotarsal formula gives the number of spines on the (side of metatibia) apex of the metatibia/ apex of first metatarsus/apex of second metatarsus.

For each picture a number of photographs were taken with a Canon 700D camera equipped with a Tamron $90 \mathrm{~mm}$ macro lens and stacked with Combine $\mathrm{Z}$ software. They were optimized with Adobe Photoshop CS3. Observations were done with a Leica MZ8 stereo microscope. The distribution maps were produced with SimpleMappr (Shorthouse 2010), which provides a delimitation of bioregions similar to that proposed by the Interim Biogeographic Regionalisation for Australia, Version 7 (see http://www.environment.gov.au/land/nrs/science/ibra). For the transcription of the labels of the types, the wording on each single label is given verbatim placed within quotes, with supplementary information not on the label given in square brackets where appropriate. In the results section, species are treated in alphabetical order.

Acronyms used for the collections are as follows:

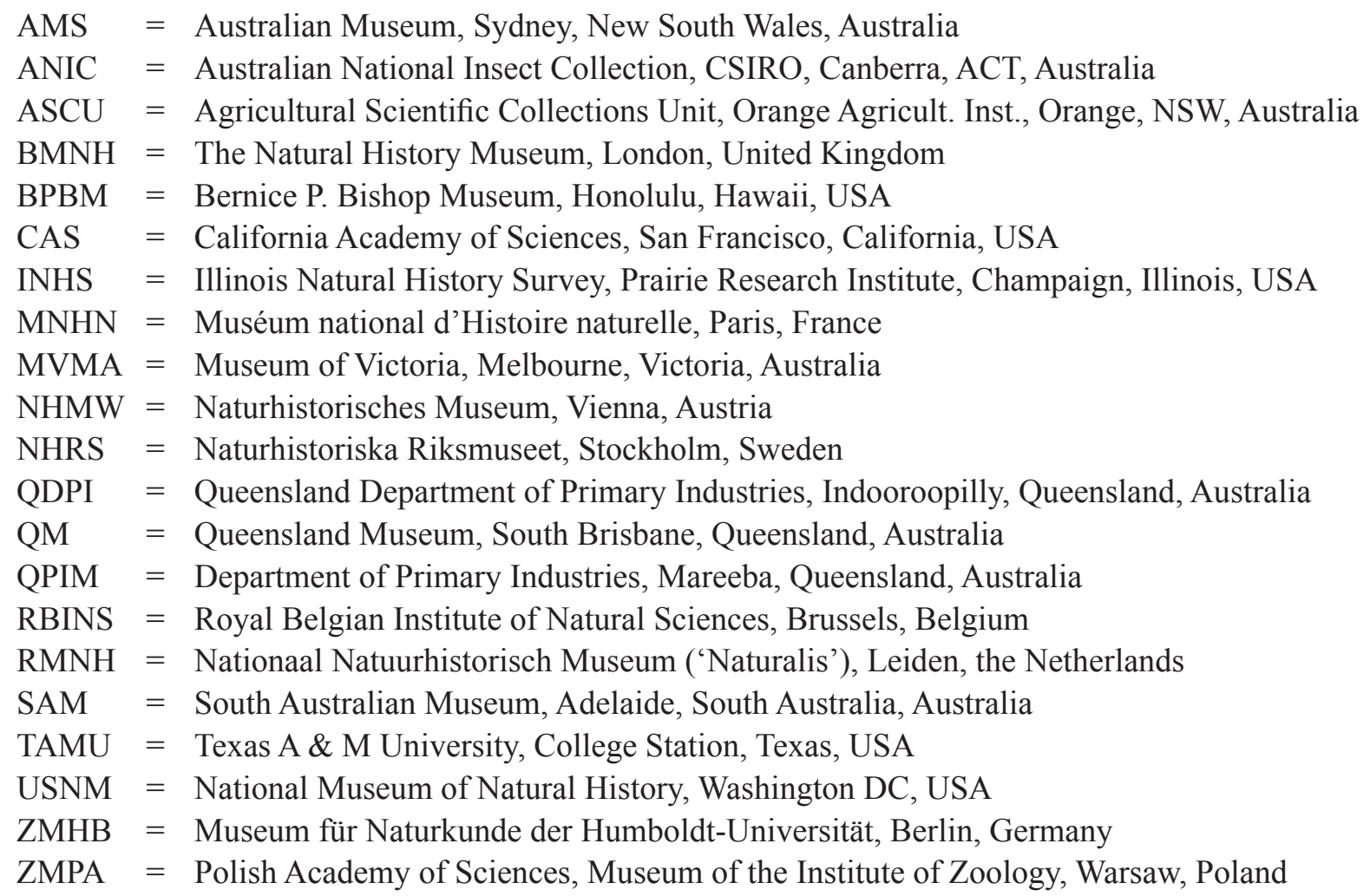




\title{
Results
}

\author{
Class Hexapoda Blainville, 1816 \\ Order Hemiptera Linnaeus, 1758 \\ Suborder Auchenorrhyncha Duméril, 1806 \\ Infraorder Fulgoromorpha Evans, 1946 \\ Superfamily Fulgoroidea Latreille, 1807 \\ Family Eurybrachidae Stål, 1862 \\ Subfamily Platybrachinae Schmidt, 1908 \\ Tribe Platybrachini Schmidt, 1908
}

Genus Olonia Stål, 1862

Figs 1-3

Olonia Stål, 1862: 488 (description in key; list of included species; type species: Eurybrachys rubicunda Walker, 1851, by subsequent designation in Distant 1906: 206).

Lyncilia Stål, 1863: 248 (description) syn. nov. (type species: Lyncilia nobilis Stål, 1863, by monotypy).

Olonia - Stål 1863: 250 (description of a new species). - Atkinson 1886: 13 (incomplete English translation of key to genera of Eurybrachidae in Stål 1862). - Karsch 1890: 60 (compared with Metoponitys Karsch, 1890); 1895: 215 (compared with Aspidonitys Karsch, 1895). - Melichar 1903: 67 (placed in a group of eurybrachid genera without a spine under the eye). - Distant 1906: 206 (type species designation, new species), 207 (compared to Yarrana Distant, 1906). — Kirkaldy 1907: 105 (listed without comment). - Schmidt 1908: 243 (placed in Platybrachini (= current Platybrachinae)). - Hacker 1924: 40 (compared with Platybrachys Stål, 1859; notes on O. viridiventris Stål, 1863 (now in Hackerobrachys Constant, 2006)). - Metcalf 1936: 131 (senior homonym of Olonia Muir, 1925); 1938: 294 (senior homonym of Olonia Muir, 1925); 1947: 163 (listed as typical genus of the Australian fauna); 1956: 63 (catalogued). - Fennah 1964: 159 (in key to genera of Platybrachini), 162 (compared with Maon Fennah, 1964). - Constant 2005a: 41 (mentioned in historical review of Metoponitys Karsch, 1890); 2006a: 47 (mentioned as needing revision); 2006b: 31 (compared with Hackerobrachys Constant, 2006 and Fletcherobrachys Constant, 2006).

Lyncilia - Karsch 1895: 215 (compared with Aspidonitys Karsch, 1895). — Schmidt 1908: 243 (placed in the Platybrachini (= current Platybrachinae)). - Metcalf 1956: 68 (catalogued). - Fennah 1964 (synonymized under Platybrachys Stål, 1859 (erroneous)).

non Olonia - Muir 1925: 161 (new genus of Cixiidae (junior homonym of Olonia Stål, 1862)). - Metcalf 1936: 131 (Muirolonia as replacement name of Olonia Muir, 1925 in Cixiidae); 1938: 294 (Muirolonia as replacement name of Olonia Muir, 1925 (Muirolonia erroneously stated as being a new genus)).

\section{Diagnosis}

Rather small-sized (6-12 $\mathrm{mm})$, dark brown variegated with black and white, tegmina usually with a white marking along costal margin on nodal line and posterior wings usually with a white marking near externoapical angle, sometimes orange on disc. The genus can be recognized by the following set of characters:

(1) gonostyli strongly sclerified and fused basally on about $1 / 3$ of length

(2) gonostyli divided into a centroventral and a laterodorsal part 
(3) gonostyli with laterodorsal part with large lateral process projecting laterally and bearing dorsoapical, articulate, spoon-shaped process

(4) aedeagus strongly reduced with dorsal portion of phallobase projecting dorsally as a spine or hook

The genus shares the condition of possessing a spoon-shaped process on the gonostyli with the Australian genera Chewobrachys Constant, 2008, Fletcherobrachys Constant, 2006, Hackerobrachys Constant, 2006, Maeniana Metcalf, 1952, Nirus Jacobi, 1928 and Stalobrachys gen. nov. but differs

- from Chewobrachys by its smaller size (6-12 $\mathrm{mm} ; 12-16 \mathrm{~mm}$ in Chewobrachys), the dark brown colour (greyish brown in Chewobrachys) and the male gonostyli divided into a centroventral and a laterodorsal part (not divided in Chewobrachys)

- from Fletcherobrachys by the bright red abdomen (green to orange in Fletcherobrachys), the hind wings brown or with discal orange marking (basal half white in Fletcherobrachys), the absence of sexual dimorphism on median tibiae (with externodistal process in females of Fletcherobrachys) and the male gonostyli fused only on basal $1 / 3$ and divided into a centroventral and a laterodorsal part (fused along most of their length and not divided in Fletcherobrachys)

- from Hackerobrachys by the frons being brown and slightly convex (bright yellow to red and strongly convex in Hackerobrachys), the posterior wings with some white and/or orange markings and rounded apically (uniformly brown with apex subquadrate in Hackerobrachys) and the male gonostyli fused only on basal $1 / 3$ and divided into a centroventral and a laterodorsal part (fused along most of their length and not divided in Hackerobrachys)

- from Maeniana by the pygofer having the posterior margin strongly sinuate (with elongate laterodorsal process projecting posteriorly in Maeniana), the gonostyli fused on about $1 / 3$ of their length (not or very shortly fused in Maeniana), and the laterodorsal part of the gonostyli with a strong spine or hook and with the lateral process bearing a spoon-shaped process (laterodorsal part elongate and laminate, without spine or hook, and bearing a spoon-shaped process apically in Maeniana)

- from Nirus by the frons being slightly convex (concave in Nirus), the pygofer broader on the dorsal $2 / 3$ (on ventral half in Nirus), and the laterodorsal part of the gonostyli with a strong spine or hook and with the lateral process bearing a spoon-shaped process (laterodorsal part of gonostyli large and laterally compressed, not strongly sclerified and without a spine or hook in Nirus)

- from Stalobrachys gen. nov. by the narrower posterior wings with LW/BW=1.7-2.0 (1.5 in Stalobrachys gen. nov.), the pygofer with the posterior margin strongly sinuate (with elongate laterodorsal process projecting posteriorly in Stalobrachys gen. nov.), the gonostyli fused on about $1 / 3$ of their length (not or very shortly fused in Stalobrachys gen. nov.), and the laterodorsal part of the gonostyli with a strong spine or hook and with the lateral process bearing a spoon-shaped process (laterodorsal part elongate and laminate, without spine or hook, and bearing a spoon-shaped process apically in Stalobrachys gen. nov.)

The genus Loisobrachys Constant, 2008 is known from a single female and was placed close to Hackerobrachys (Constant 2008b). Hence, the males of the genus potentially share the condition of possessing gonostyli with a spoon-shaped process. However, Olonia can easily be separated from Loisobrachys by its slightly convex frons (strongly convex in Loisobrachys). 


\section{Historical review}

\section{Historical characters recognition review}

Olonia was described by Stål (1862) within a key to the genera of Eurybrachidae without a spine under the eyes and with the clavus of the tegmina closed. From the key, the following characters could be extrapolated to define Olonia:

(1) posterior tibiae with 3 lateral spines

(2) frons transverse, with sides angulate

(3) pro- and mesonotum broader than combined length

(4) antennae short, placed under the eye

More recently, a key to the genera of Platybrachini was proposed by Fennah (1964), including Olonia for which the following distinctive combination of characters could be extrapolated:

(1) tegmina with $\mathrm{CuA}$ vein forked close to the nodal line

(2) tegmina with MP vein forked very close to the base

(3) genae without knob-like process under the eye

(4) frons more or less flat, without depressed areas near the base

(5) antennae not surpassing the eyes

(6) genital styles (= gonostyli) of male separated

Characters (2) and (6) are not correct: in Olonia, the MP is not forked very close to the base and Fennah's statement probably comes from confusion with the ScP and RP, which diverge very basally, and the gonostyli in the male genitalia are fused basally.

\section{Historical species review}

Stål (1862) erected the genus Olonia for three species from Australia, Eurybrachys rubicunda Walker, 1851, E. apicalis Walker, 1851 and E. transversa Walker, 1858. The year after, Stål (1863) added one species from Queensland, $O$. viridiventris Stål, 1863. Species were progressively added to the genus: O. picea by Kirkaldy (1906) (Queensland), O. marginata by Distant (1906) (Queensland), O. alboapicata and $O$. nigroapicata by Jacobi (1928) (Queensland and Western Australia, respectively), and O. ornata by Lallemand (1928) (Northern Territory). Jacobi (1928) synonymized O. picea Kirkaldy, 1906 with $O$. transversa (Walker, 1858), a view that I did not follow (Constant 2005b), restoring O. picea as a separate species and considering $O$. transversa as a nomen dubium because the available specimen labelled as type in BMNH does not match the original description by Walker (1858). One last species, Cicada maura Fabricius, 1775, was transferred to Olonia by Evans (1933) after being placed in the genus Eurymela Le Peletier \& Serville, 1825 (Cicadellidae: Eurymelinae) for more than a century. Metcalf (1956) included 9 species in the genus in his catalogue of the Eurybrachidae. More recently, I transferred O. viridiventris Stål, 1863 to the genus Hackerobrachys Constant, 2006 and synonymized O. nigroapicata Jacobi, 1928 with Fletcherobrachys stillata (Bergroth, 1907) (Constant 2006b).

\section{Historical classification review}

The genus Olonia was placed by Schmidt (1908) in the tribe Platybrachini Schmidt, 1908 (equivalent to the present Platybrachinae, as the family Eurybrachidae was at that time treated as a subfamily of the Fulgoridae) based on the following set of characters:

(1) clavus closed, with the claval veins (= Pcu and A1) fused before the apex of the clavus and Pcu+A1 reaching the apex of the clavus

(2) ventral margin of eyes without a spine

Metcalf (1956) placed the genus in the tribe Platybrachini of the Platybrachinae, a view followed by Fennah (1964). 


\section{Description}

Colouration. Head, pro- and mesonotum, and tegmina brown, from pale brown to nearly black, usually variegated with darker and paler areas. Tegmina often with yellowish marking in middle of clavus on vein A1; triangular white marking along costal margin on nodal line, rarely missing; smaller white marking at apicosutural angle, rarely missing; sometimes white marking along costal margin at midlength. Posterior wings brown, usually darker on apical half; sometimes with orange marking in middle; white triangular marking at apicocostal angle, rarely missing. Pro- and mesofemora with 2 pale rings, obsolete in dark species; pro- and mesotibiae with 3 pale rings, obsolete in dark species; metafemora red to brown, darker apically; metatibiae brown. Abdomen and ventral face of thorax bright red; genital segments brown to black; abdominal segment VII white in females.

HEAD. As broad as thorax; vertex $4-5$ times as broad as long, concave, with all margins slightly carinate; anterior and posterior margins rounded, parallel; frons about 1.7-1.95 times as broad as long, slightly convex, slightly wrinkled to rugulose, with peridiscal carina slightly marked; upper margin of frons straight in normal view; clypeus slightly surpassing anterior trochanters, elongate, with median carina towards apex; labium reaching hind coxae, with apical segment longer than broad, acuminate, shorter and more slender than penultimate; no infra-ocular spines on genae; ocelli absent; antennae elongate, not surpassing eye, not visible from above; scape about as long as broad, pedicel subcylindrical, elongate, narrowing towards apex.

THORAX. About 1.45 times as broad as combined length of pro- and mesonotum; pronotum about half as long as mesonotum; pronotum with disc weakly wrinkled, carina parallel to anterior margin and with two slightly impressed points on disc; mesonotum with disc weakly wrinkled, median and peridiscal carinae slightly marked.

TEGMina. Slightly convex in smaller species to nearly flat in the larger ones; curving down at nodal line, often with apex slightly curved upwards; elongate, about 2.1-2.5 times as long as broad; costal margin slightly sinuate; apical margin obliquely rounded; sutural margin slightly oblique after clavus. Venation: veins $\mathrm{ScP}+\mathrm{RA}$ and RP separated close to base; first fork of MP on basal $1 / 3$; first fork of $\mathrm{CuA}$ slightly before apex of clavus; clavus closed; Pcu and A1 fused at $2 / 3$ of clavus length; Pcu+A1 reaching apical angle of clavus; numerous elongate cells along posterior half of costal margin and along apical margin.

Posterior Wings (Fig. 1A). Well developed, about as broad as tegmina, rounded apically; moderately narrow: $\mathrm{LW} / \mathrm{BW}=1.7-2.0$; anal area moderately developed; sutural margin weakly trilobous; not reaching apex of tegmina at rest; dark brown to black, with apicosutural triangular white spot, rarely missing; sometimes with central, small to very large, orange marking. All main veins visible from base, forked after nodal line and sometimes forming closed cells; transverse veinlets delimiting elongate cells on apical $1 \frac{1}{3}$; veins A1 and A2 sometimes with 2-3 terminals. Arrangement of secondary veins and veinlets variable between specimens and sometimes between the two wings of the same specimen.

LEGS. Pro- and mesofemora and -tibiae dorsoventrally flattened, elongate and slender; metatibiae with 3 lateral and 9 apical spines; first metatarsomere ventrally with pad of microsetae at interno-apical angle and group of 6 spines (Fig. 1B). Metatibiotarsal formula: (3) 9/4/0.

Male genitalia. Pygofer rather short, higher than long and sinuate in lateral view; posterior margin roundly projecting at dorsal $1 / 3$. Anal tube dorsoventrally flattened, elongate, with lateral margins usually curved lateroventrally; epiproct at basal $1 / 3$. Gonostyli fused basally, well sclerified, deeply divided in centroventral and laterodorsal parts, elongate and spinose or sword-shaped; laterodorsal part with strong spine or hook, sometimes bifid, and with large lateral process projecting laterad and bearing dorsoapical, articulate, spoon-shaped process. Aedeagus strongly reduced; dorsal portion of phallobase 
point- or hook-shaped; ventral portion of phallobase as more or less reduced, sclerified lamina; phallus membranous, dorsoventrally flattened.

Female terminalia (Fig. 2) (based on $O$. marginata). Abdominal segment VI slightly broader apically and with posterior margin largely emarginate medially in ventral view, and with a small process projecting lateroventrally on each side of emargination (Fig. 2C); anal tube elongate and narrow, curved postero-ventrad, v-shaped in cross section beyond anus, lanceolate in dorsal view (Fig. 2A-B, D-E); gonoplacs unilobed, projecting dorsolaterad, longer than high, not surpassing anal tube (Fig. 2A-B, D-E); gonapophysis IX large, elongate, apically rounded and curved dorsad (Fig. 2A-B, D-E); gonocoxae VIII resembling reniform inflated pouch (Fig. 2A-E); gonapophysis VIII dorsoventrally flattened and fused together and with sternite VII in a large semicircular lobe slightly emarginate apically (Fig. 2A-E); anterior vagina small and membranous; posterior vagina strongly sclerified, dorsoventrally flattened, short and broad basally, constricted and subtriangular distally (Fig. 2D); bursa copulatrix attached posterodorsally, oval, much larger than posterior vagina (Fig. 2D-E); walls bearing weak, longitudinally reticulated ornamentation (Fig. 2D-E).

SeXual Dimorphism. Females slightly larger than males. Colour dimorphism also present, in different patterns according to species, sometimes combined:

(1) white markings on anterior and posterior wings more developed in males

(2) orange marking on posterior wing larger in males

(3) apical margin of tegmina and posterior wings bordered with white in females, not in males

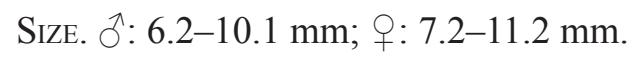
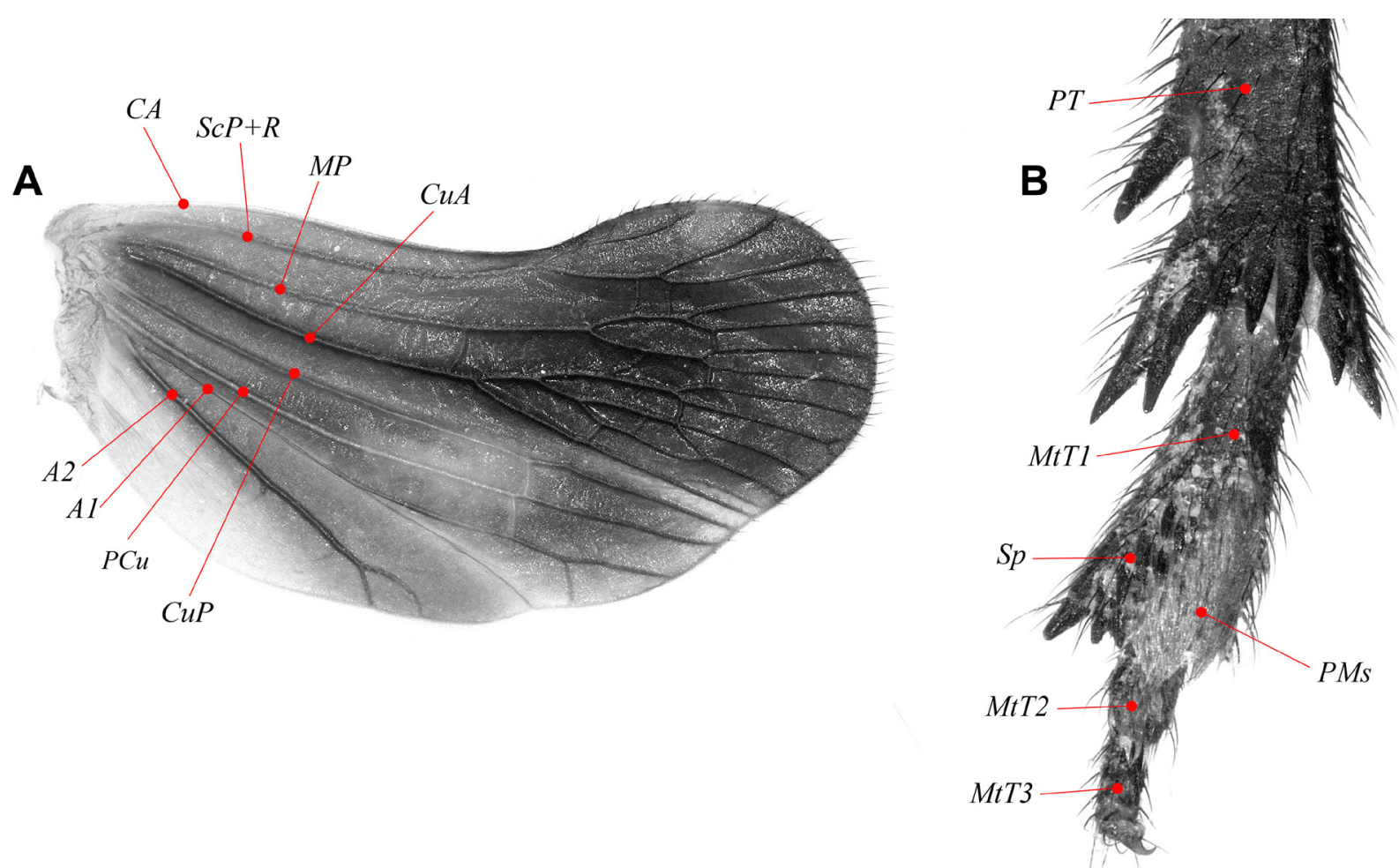

Fig. 1. Olonia Stål, 1862. A. Right posterior wing, venation. B. Right posterior leg, distal portion, ventral view. Abbreviations: $A 1=$ first anal vein; $A 2=$ second anal vein; $C A=$ costa anterior; $C u A=$ cubitus anterior; $C u P=$ cubitus posterior; $M P=$ media posterior; $M t T 1=$ first metatarsomere; $M t T 2=$ second metatarsomere; $M t T 3=$ third metatarsomere; $P C u=$ postcubitus; $P M s=$ pad of microsetae; $P T=$ posterior tibia; $S c P+R=$ subcosta posterior + radius; $S p=$ spines. 

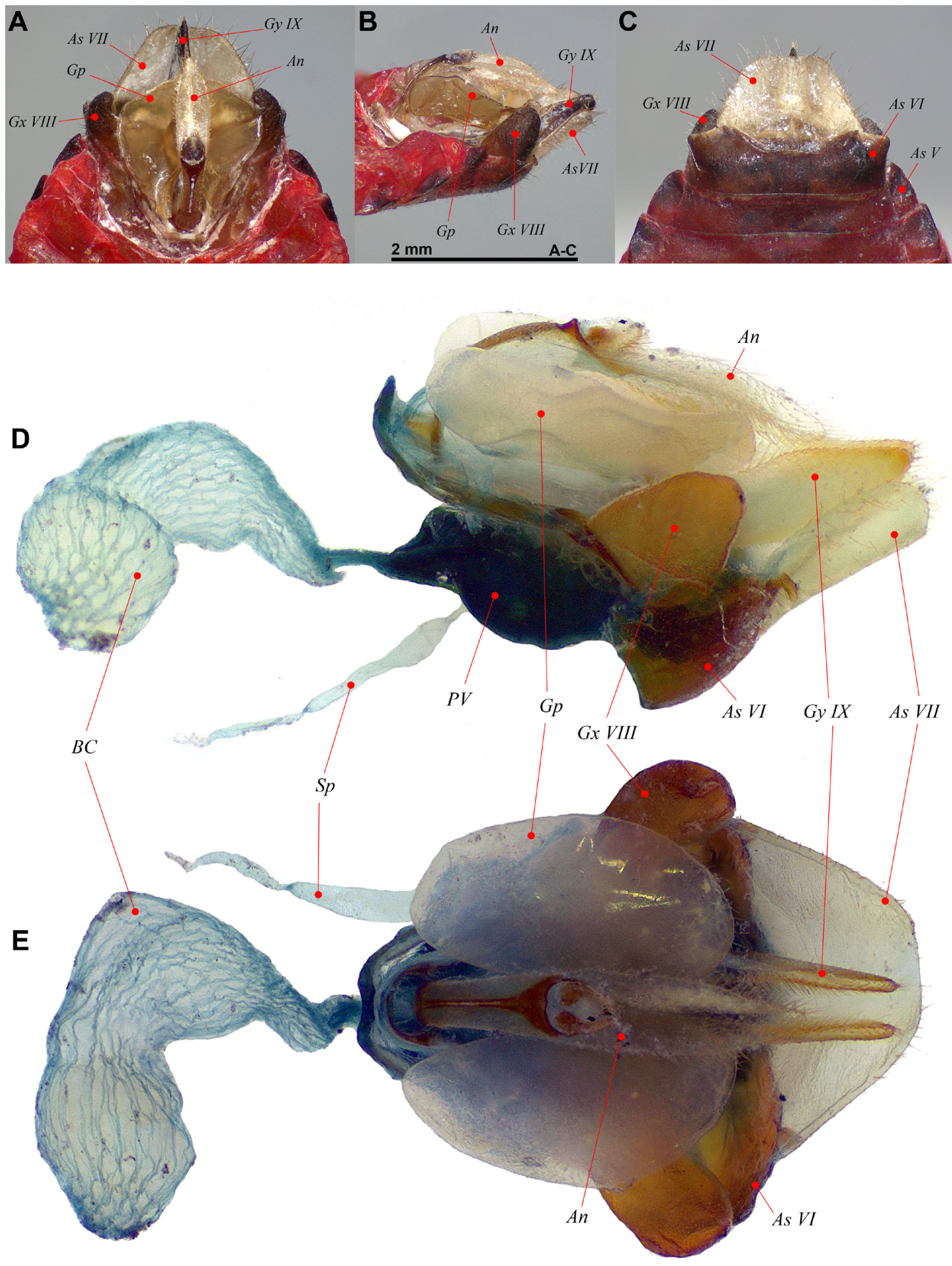

$2 \mathrm{~mm}$

D-E

Fig. 2. Olonia Stål, 1862, female genitalia. A. External aspect, dorsal view. B. External aspect, left lateral view. C. External aspect, ventral view. D. Dissected, left lateral view. E. Dissected, dorsal view. Abbreviations: $A n=$ anal tube; $A s V=$ fifth abdominal sternite; $A s V I=$ sixth abdominal sternite; As VII = seventh abdominal sternite; $B C=$ bursa copulatrix; $G p=$ gonoplac; $G x$ VIII = gonocoxa VIII; $G y I X=$ gonapophysis IX; $P V=$ posterior vagina; $S p=$ spermatheca. 


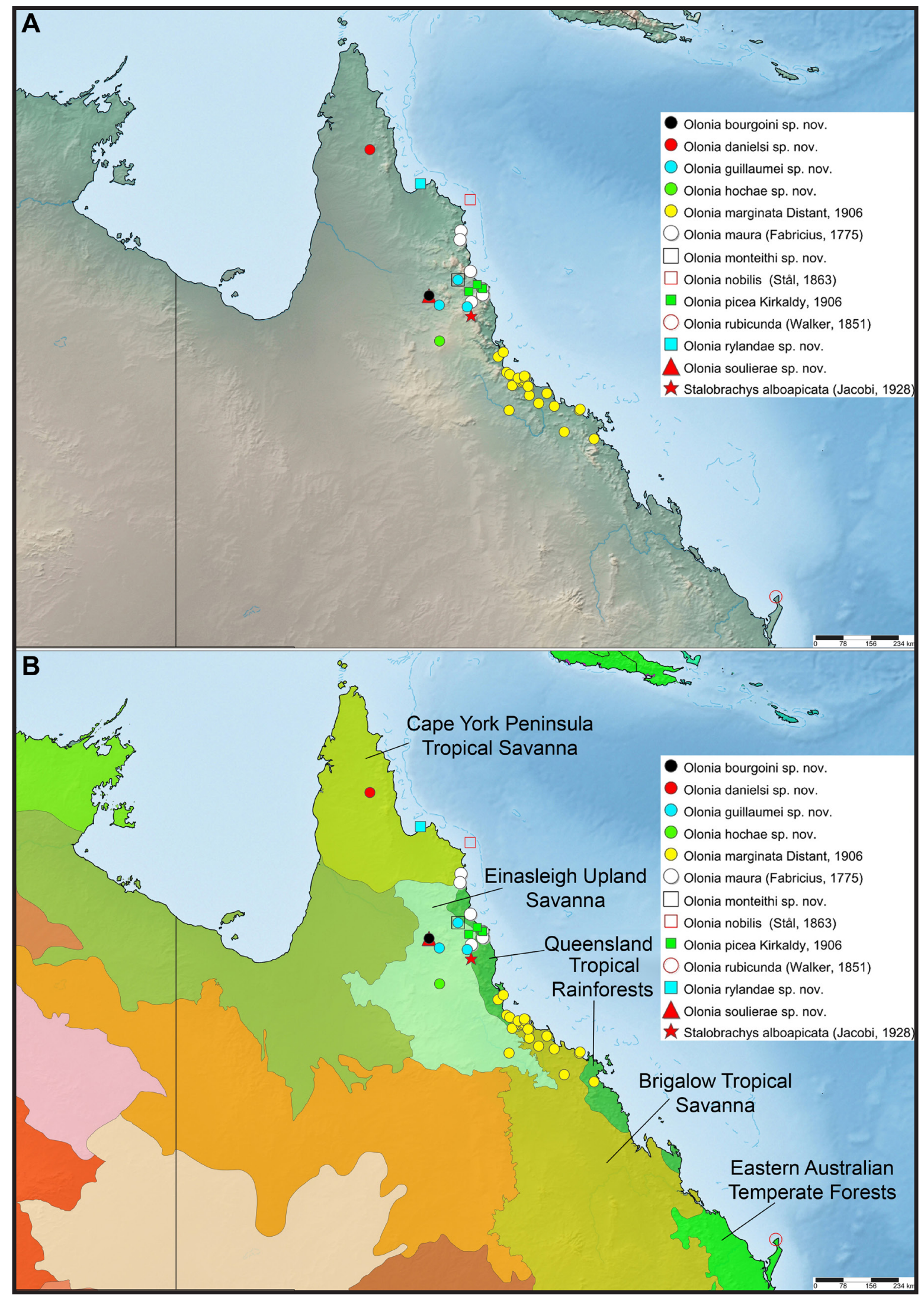

Fig. 3. Olonia spp. and Stalobrachys alboapicata gen. et comb. nov. (Jacobi, 1928), distribution maps. A. Topographic map. B. Bioregion map. 


\section{Distribution}

Australia: eastern and northern Queensland, also on islands (Fig. 3).

\section{Biology}

According to the available data, species of Olonia seem to be present all year round and to be polyphagous, living on plants close to the ground. They were recorded from plants in the families Bursaceae, Convolvulaceae, Myrtaceae, Solanaceae, Urticaceae and Vitaceae. Known habitats range from open forests to beaches. All species seem to have a rather restricted distribution. Species of Olonia are present in all bioregions included in the distribution range of the genus (Fig. 3B).

\section{Species included (12)}

O. bourgoini sp. nov.

O. danielsi sp. nov.

O. guillaumei sp.nov.

O. hochae sp. nov.

O. marginata Distant, 1906

O. maura (Fabricius, 1775)

O. monteithi sp. nov.

O. nobilis (Stål, 1863) comb. nov.

O. picea Kirkaldy, 1906

O. rubicunda (Walker, 1851)

O. rylandae sp. nov.

O. soulierae sp. nov.

\section{Remarks}

Olonia apicalis (Walker, 1851) and Olonia ornata Lallemand, 1928 are here excluded from Olonia and transferred to Maeniana Metcalf, 1952 and Platybrachys Stål, 1859, respectively (see below).

\section{Identification key to the species of Olonia}

The following key uses the characters of the male genitalia; O. rubicunda (Walker, 1851) is not included, as it is only known from a single female. Females should not be identified unless a male from the same collecting event is available to support the identification.

1. Process of the laterodorsal part of gonostyli bifid (Figs 30D, 33D)

- Process of the laterodorsal part of gonostyli not bifid (Figs 5D, 10D, 19D) ....................................

2. Process of the centroventral part of gonostyli with several teeth apically (Fig. 30C)

o. maura (Fabricius, 1775)

- Process of the centroventral part of gonostyli without teeth apically (Figs 33C, 42C)

3. Processes of the laterodorsal part of gonostyli convergent apically, subequal in length and surpassing process of centroventral part in ventral view (Fig. 42A, C-D) ...O. picea (Kirkaldy, 1906)

- Processes of the laterodorsal part of gonostyli slightly diverging apically with dorsal one shorter than ventral one, and not reaching level of apex of process of centroventral part in ventral view (Fig. 33A, C-D) . O. monteithi sp. nov.

4. Processes of the laterodorsal part of gonostyli surpassing processes of centroventral part in ventral view (Figs 19C, 46C)

- Processes of the laterodorsal part of gonostyli shorter than processes of centroventral part in ventral view (Figs 5C, 10C, 37C) .6 
5. Processes of the laterodorsal part of gonostyli strongly sinuate with central portion straight (Fig. 46A, C)

o. rylandae sp. nov.

- Processes of the laterodorsal part of gonostyli strongly and regularly curved ventrally (Fig. 19A, C) O. marginata Distant, 1906

6. Anal tube elongate and narrow, more than 3 times as long as broad, with sides subparallel (Figs 5B, 10B)

- Anal tube broader, less than 2.5 times as long as broad, with sides curved (Figs 8B, 37B) ..........9

7. Processes of the laterodorsal part of gonostyli falcate, broader at midlength and incurved (Fig. 5A, $\mathrm{C}-\mathrm{D})$ O. bourgoini sp. nov.

- Processes of the laterodorsal part of gonostyli regularly narrowing from base to apex and not incurved (Fig. 10A, C-D)

8. Processes of the laterodorsal part of gonostyli curved laterally (Fig. 10C-D); process of centroventral part of gonostyli with ventral margin convex in lateral view (Fig. 10A)

O. guillaumei sp. nov.

- Processes of the laterodorsal part of gonostyli curved ventrally (Fig. 13C-D); process of centroventral part of gonostyli with ventral margin slightly concave in lateral view (Fig. 13A)

o. hochae sp. nov.

9. Anal tube with apical margin notched and lateral margins subparallel beyond epiproct (Fig. 48B); process of centroventral part of gonostyli very elongate and narrow (Fig. 48A, C)

O. soulierae sp. nov.

- Anal tube with apical margin not notched and lateral margins not subparallel beyond epiproct (Figs $8 \mathrm{~B}, 37 \mathrm{~B}$ ); process of centroventral part of gonostyli not very elongate and narrow (Figs 8A, C, $37 \mathrm{~A}, \mathrm{C})$

.10

10. Processes of the centroventral part of gonostyli incurved and slightly surpassing processes of lateroventral part in ventral view (Fig. 37C); anal tube regularly narrowing beyond epiproct (Fig. 37B)

O. nobilis (Stål, 1863)

- Processes of the centroventral part of gonostyli strongly hooked dorsally at apex and strongly surpassing processes of lateroventral part in ventral view (Fig. $8 \mathrm{C}$ ); anal tube broadening beyond epiproct to $2 / 3$ of its length (Fig. 8B)

o. danielsi sp. nov.

\author{
Olonia bourgoini sp. nov. \\ urn:1sid:zoobank.org:act:E8E1C13D-620D-499D-860C-8A6288526E9D
}

Figs 3-6

\title{
Diagnosis
}

This species can be recognized by the following combination of characters:

(1) hind wings with conspicuous orange marking (Figs 4E, 6E)

(2) pro- and mesofemora and tibiae largely yellowish (Figs 4A-B, 6A-B)

(3) anal tube of male oblong with posterior margin emarginate (Fig. 5B)

(4) centroventral part of gonostyli with long laminate process (Fig. 5A, C)

(5) laterodorsal part of gonostyli with falcate process directed centroventrally (Fig. 5A, C-D)

(6) rather large size: $9-10 \mathrm{~mm}$

\section{Etymology}

This species is dedicated to Prof. Dr Thierry Bourgoin (MNHN), who collected the specimens of the type series. 


\section{Material examined}

Holotype

AUSTRALIA - ${ }^{\top}$; Queensland, Chillagoe Haunted Cave; $17^{\circ} 06^{\prime} \mathrm{S}, 144^{\circ} 25^{\prime}$ E; "Muséum Paris, Australie (Queensland) Près de Chilagoe Hounted Cave-Cave 1", "S1706' E144²5', 13.III.1997, A. SoulierPerkins \& Th. Bourgoin rec.”, "QM-T244701”; QM.

Paratypes

AUSTRALIA • 1 ऊ; same collection data as for holotype; MNHN • 1 क ; “Australie, Chilagoe GPS 300, 11/12-III-1997, Th. Bourgoin réc.”, "Muséum Paris, piège lumineux, Th. Bourgoin réc.”; MNHN.

\section{Note}

On the labels of these specimens, "Chilagoe" and "Hounted" should be spelled "Chillagoe" and "Haunted", respectively.

\section{Description}

MeAsurements and Ratios. LT: $\widehat{\partial}(\mathrm{n}=1): 9.15 \mathrm{~mm} ;$; $(\mathrm{n}=1): 9.7 \mathrm{~mm} ; \mathrm{BV} / \mathrm{LV}=4.2 ; \mathrm{BF} / \mathrm{LF}=1.75$; $\mathrm{LP}+\mathrm{LM} / \mathrm{BT}=0.7 ; \mathrm{Ltg} / \mathrm{BTg}=2.4 ; \mathrm{LW} / \mathrm{BW}=1.77$.

\section{Male}

HEAD (Fig. 4A-D). Vertex concave with anterior and posterior margins parallel, curved; variegated brown and yellow-brown with darker marking at lateral angles. Frons pale yellowish variegated with brown, with superolateral and dorsal margins broadly bordered with black and 2 transverse, aligned black markings above middle. Clypeus elongate, pale yellowish, with basal, black, horseshoe-shaped marking and oblique brown lines on sides. Genae pale yellowish, slightly darker around eyes. Labium dark brown, reaching metacoxae. Antennae dark brown, paler dorsally; scape short, ring-shaped; pedicel subcylindrical, slightly narrowing towards apex.

Thorax (Fig. 4A-D). Pronotum brown variegated with yellowish and with blackish marking; obsolete median carina and 2 small impressed points on disc. Lateral fields of prothorax brown, turning to pale yellowish ventrally. Mesonotum brown variegated with yellowish and black markings along median carina and along external side of peridiscal carinae; median and peridiscal carinae weakly marked; median carina stopping before scutellum; slight impression before scutellum. Red ventrally. Tegulae dark brown, paler dorsally.

Tegmina (Fig. 4A, C). Brown variegated with yellowish; broad apical band and irregular markings along basal and costal margins black; pale yellow line on vein A1 at half length of clavus; large triangular white marking on costal margin on nodal line; white spot at apicosutural angle. Maximum breadth at nodal line; costal margin slightly sinuate; apical margin obliquely rounded.

Posterior wings (Fig. 4E). Black-brown with darker marking at base of apical half along costal margin; elongate, transverse, with triangular white marking at apicocostal angle, extending on 6 cells; elongate orange marking between anal fold and vein $\mathrm{CuP}$ at $2 / 3$, not reaching margin. Margin of anal area sinuate; sutural margin with 2 clefts, cubital one slightly marked.

Legs (Fig. 4A-D). Pro- and mesocoxae yellowish. Pro- and mesofemora yellowish with some brown markings and with black markings near apex. Pro- and mesotibiae yellowish with 3 ring-shaped black markings, larger one near apex. Pro- and mesotarsi brown with basal half of third tarsomere yellowish. Metacoxae and metafemora reddish yellow. Metatibiae yellowish with 3 lateral and 8 apical blackbrown spines. Metatarsi yellowish with a ventral row of 6 black spines on first tarsomere.

ABDOMEN. Bright red with genital segments black-brown. 

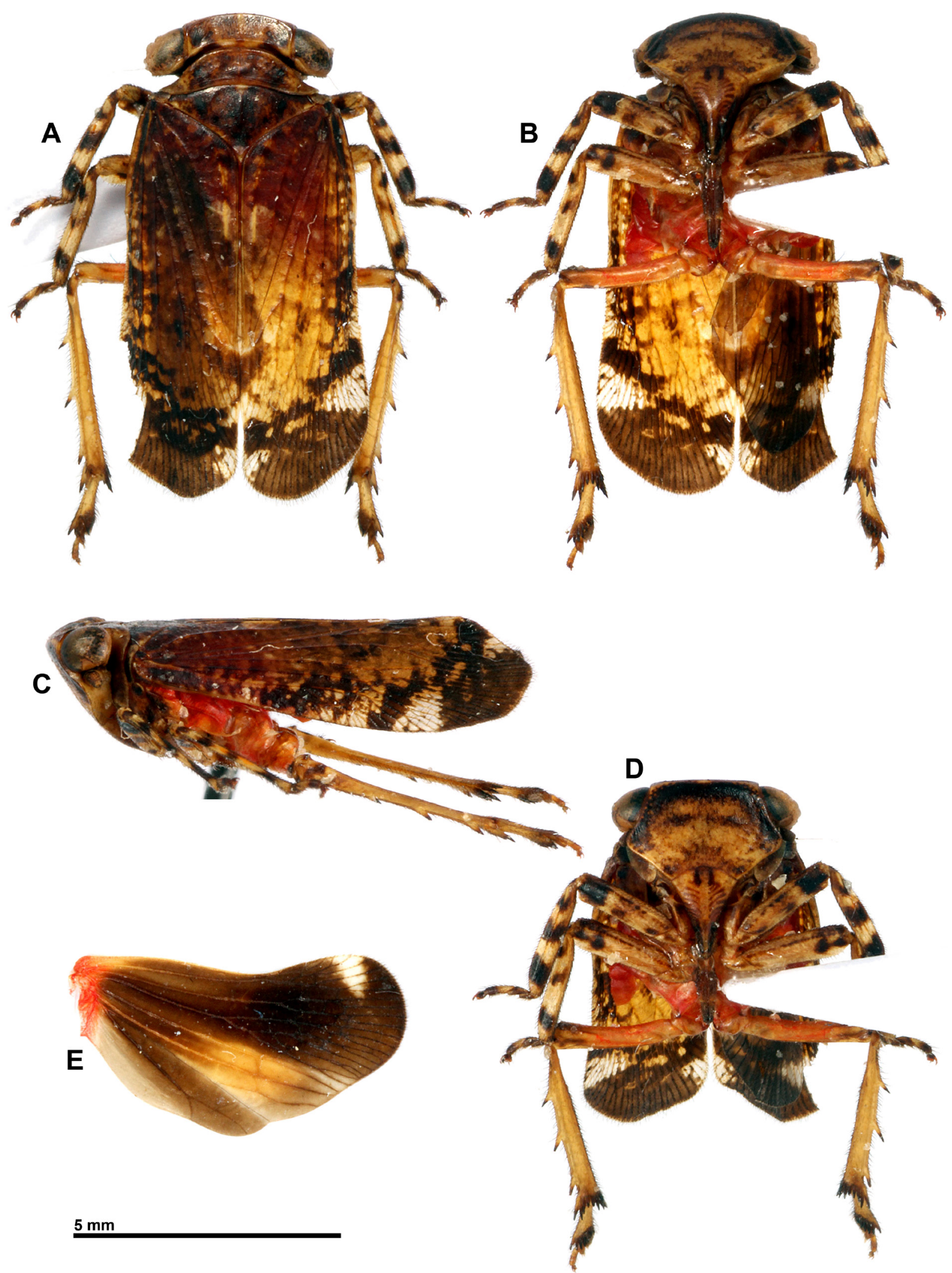

Fig. 4. Olonia bourgoini sp. nov., holotype, §. A. Habitus, dorsal view. B. Habitus, ventral view. C. Habitus, lateral view. D. Habitus, normal view of frons. E. Posterior wing. 


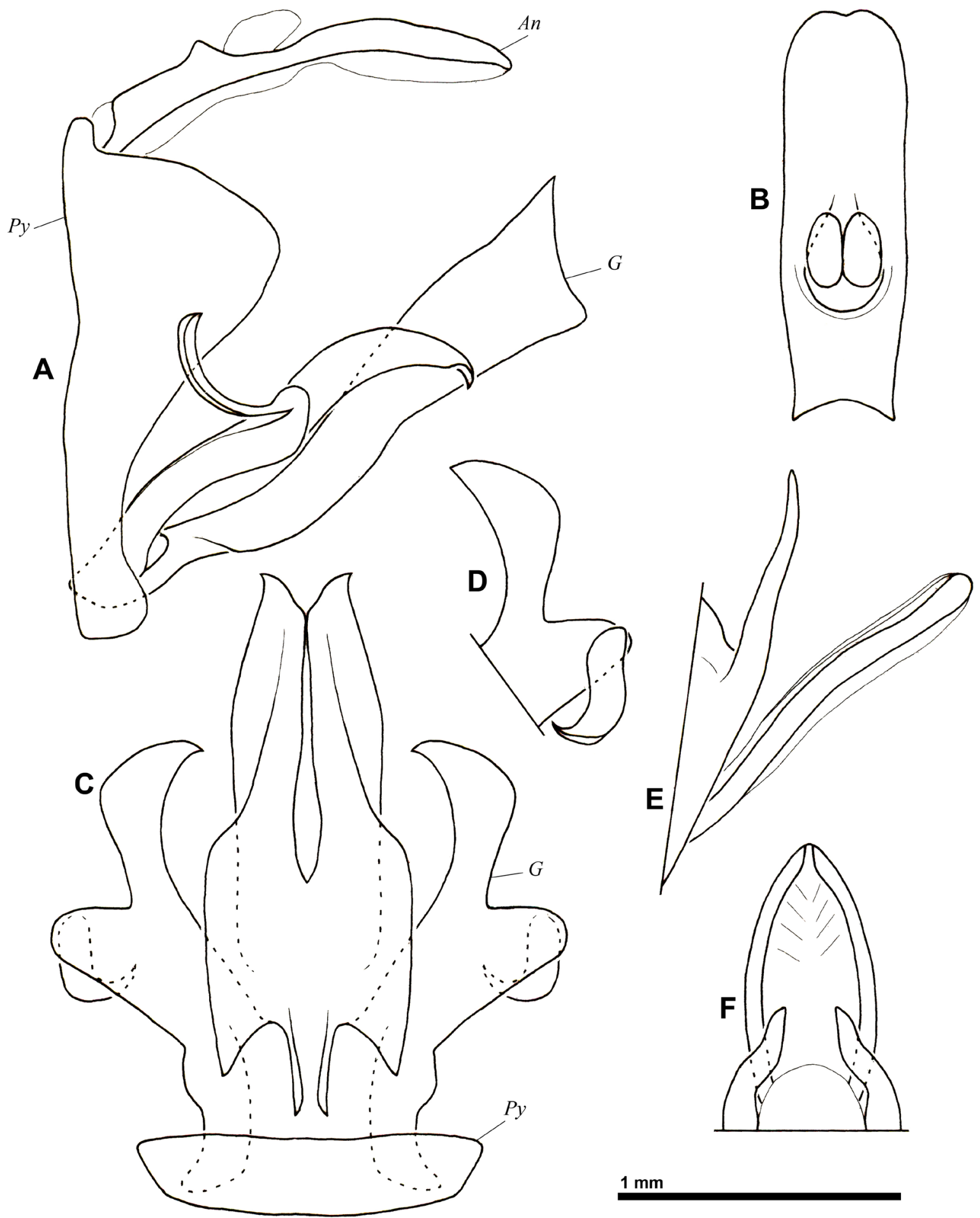

Fig. 5. Olonia bourgoini sp. nov., holotype, $\widehat{O}$, genitalia. A. Pygofer, anal tube and gonostyli, left lateral view. B. Anal tube, dorsal view. C. Pygofer and gonostyli, ventral view. D. Laterodorsal part of left gonostylus, dorsal view. E. Aedeagus, left lateral view. F. Aedeagus, dorsal view. Abbreviations: $A n=$ anal tube; $G=$ gonostyli; $P y=$ pygofer. 

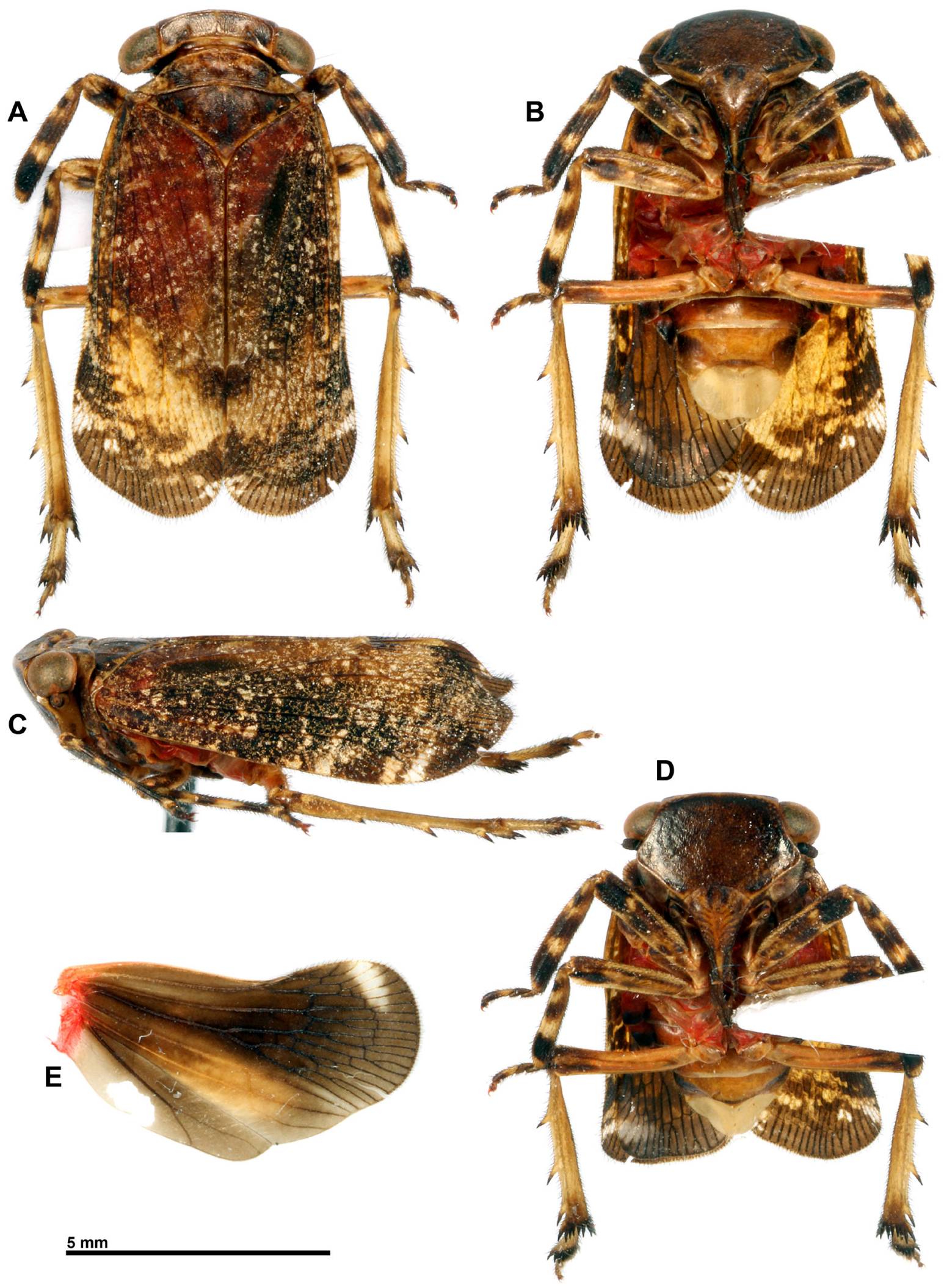

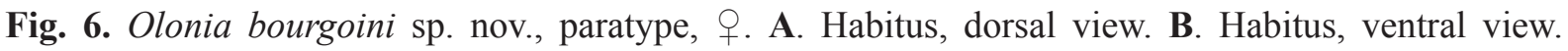
C. Habitus, lateral view. D. Habitus, normal view of frons. E. Posterior wing. 
Male Genitalia (Fig. 5). Posterior margin of pygofer in lateral view strongly sinuate, strongly roundly projecting at dorsal 1/3, narrow ventrally (Fig. 5A, C). Anal tube oblong, 3.15 times as long as broad, slightly curved ventrally in lateral view; lateral margins subparallel and slightly curved ventrally; apical margin emarginate in middle (Fig. 5A-B). Gonostyli fused to nearly half length of centroventral part and projecting posterodorsally (Fig. 5A, C). Centroventral part dorsoventrally flattened basally, progressively twisted and laminate towards apex, broader apically in lateral view, with apical margin concave, apicodorsal angle pointed and apicoventral angle angularly rounded (Fig. 5A, C). Laterodorsal part of gonostyli curved centroventrally, falcate and slightly concave ventrally, with lateral process rather broad and shorter than spoon-shaped process (Fig. 5A, C-D). Dorsal portion of phallobase with elongate process on each side, pointing dorsally and slightly curved internally at base (Fig. 5E). Ventral portion of phallobase along lateral margin of phallus, elongate, curved internally and nearly merging together apically, directed posterodorsally (Fig. 5E-F). Phallus dorsoventrally flattened, lanceolate in dorsal view (Fig. 5E-F).

\section{Female}

Similar to male but with frons entirely brown and with white markings of tegmina smaller (Fig. 6).

\section{Distribution and biology}

This species is currently recorded from a single location in tropical Queensland, near Chillagoe, in the Einasleigh Upland Savanna bioregion (Fig. 3). The specimens were collected in March.

$$
\begin{aligned}
& \text { Olonia danielsi sp. nov. } \\
& \text { urn:1sid:zoobank.org:act:9CDEEFAE-CD5C-4E43-AC95-20D939A1521A }
\end{aligned}
$$

Figs $3,7-8$

\section{Diagnosis}

This species can be recognized by the following combination of characters:

(1) hind wings without orange marking (Fig. 7E)

(2) pro- and mesofemora and tibiae largely dark brown (Fig. 7A-D)

(3) anal tube of male narrow and parallel-sided on basal third, then subrhomboid (Fig. 8D)

(4) centroventral part of gonostyli with long laminate process hooked apically (Fig. 8A, C)

(5) laterodorsal part of gonostyli strongly curved before apex and pointing laterodorsally (Fig. 8A, C-D)

(6) rather large size: $10 \mathrm{~mm}$

\section{Etymology}

This species is dedicated to Greg Daniels who collected the holotype, together with his wife Alice.

\section{Type material}

\section{Holotype}

AUSTRALIA - $\mathrm{O}^{\wedge}$; Queensland, $3 \mathrm{~km} \mathrm{NW}$ of Archer River crossing; $13^{\circ} 24^{\prime} \mathrm{S}, 142^{\circ} 55^{\prime} \mathrm{E}$; " $3 \mathrm{~km} \mathrm{NW}$ Archer Riv x-ing, Qld 1324'S 142 55'E, 10 Apr 1989, G. and A. Daniels", “QM Reg. \#43783”; QM.

\section{Description}

Measurements and Ratios. $\mathrm{LT}: \widehat{\jmath}(\mathrm{n}=1): 10.0 \mathrm{~mm} ; \mathrm{BV} / \mathrm{LV}=4.7 ; \mathrm{BF} / \mathrm{LF}=1.95 ; \mathrm{LP}+\mathrm{LM} / \mathrm{BT}=0.72$; $\mathrm{Ltg} / \mathrm{BTg}=2.3 ; \mathrm{LW} / \mathrm{BW}=1.86$.

\section{Male}

HEAD (Fig. 7A-D). Vertex concave with anterior and posterior margins parallel, curved; variegated brown and yellow-brown with darker marking at lateral angles. Frons brown variegated with yellowish, 
with 2 irregular black markings on disc. Clypeus elongate, brown variegated with yellowish, and darker apically. Genae pale yellowish, with brown markings around eyes and under antennae. Labium dark brown, reaching metacoxae. Antennae dark brown; scape short, ring-shaped; pedicel subcylindrical, slightly narrowing towards apex.

THorax (Fig. 7A-D). Pronotum brown variegated with yellowish and with 2 small yellowish spots near lateral angles; obsolete median carina and 2 small impressed points on disc. Lateral fields of prothorax brown. Mesonotum brown variegated with yellowish; broad, irregular, black marking along median carina; disc slightly transversely wrinkled; median and peridiscal carinae weakly marked; median carina stopping before scutellum; slight impression before scutellum. Red ventrally. Tegulae brown, paler dorsally.

TEGmina (Fig. 7A, C). Brown variegated with yellowish and black; large, irregular, apical black marking; pale yellow, oblique, sinuate line on vein A1 at half length of clavus; large triangular white marking on costal margin on nodal line, slightly variegated with brown; white marking at apicosutural angle, slightly variegated with brown. Maximum breadth at nodal line; costal margin slightly sinuate; apical margin obliquely rounded.

PosTERIOR WINGS (Fig. 7E). Black-brown, paler near base along costal and anal margins and along anal fold; elongate, transverse, rather small white marking at apicocostal angle, extending on 3 cells. Margin of anal area sinuate; sutural margin with 2 clefts, cubital one slightly marked.

LeGs (Fig. 7A-D). Pro- and mesocoxae yellowish brown. Pro- and mesofemora dark brown with 2 obsolete yellowish rings. Pro- and mesotibiae dark brown with 2 slightly marked yellowish rings. Proand mesotarsi brown with basal half of third tarsomere paler. Metacoxae red. Metafemora reddish yellow with apex brown. Metatibiae brown with 3 lateral spines yellowish basally and 8 apical black-brown spines. Metatarsi brown with a ventral row of 6 black spines on first tarsomere.

ABDomen. Bright red with genital segments black-brown.

Male Genitalia (Fig. 8). Posterior margin of pygofer in lateral view strongly sinuate, strongly roundly projecting at dorsal 1/3, rather broad ventrally (Fig. 8A, C). Anal tube elongate, 2.05 times as long as broad, slightly curved ventrally in lateral view; lateral margins parallel on basal $1 / 3$, rhomboid on apical $2 / 3$ with posterior margin rounded (Fig. 8A-B). Gonostyli fused basally and coalescent on $4 / 5$ of length; diverging apically (Fig. 8C). Centroventral part elongate, laterally compressed and ending in a strong hook pointing dorsally (Fig. 8A, C). Laterodorsal part of gonostyli strongly sinuate in dorsal view with apical part strongly curved and directed dorsolaterally; lateral process in more dorsal position, slightly curved ventrally near apex and slightly directed anteriorly, longer than spoon-shaped process (Fig. 8A, C-D). Dorsal portion of phallobase high basally in lateral view, directed posteroventrally and with apical hook strongly curved dorsally (Fig. 8E). Ventral portion of phallobase along lateral margin of phallus, weakly sclerified, laterally flattened, elongate (Fig. 8E-F). Phallus dorsoventrally flattened, narrowing, bifid and slightly diverging apically in dorsal view (Fig. 8E-F).

\section{Female}

Unknown.

\section{Distribution and biology}

This species is currently recorded from a single location on Cape York Peninsula, Queensland (Fig. 3), in the Cape York Peninsula Tropical Savanna bioregion. The specimen was collected in April. 


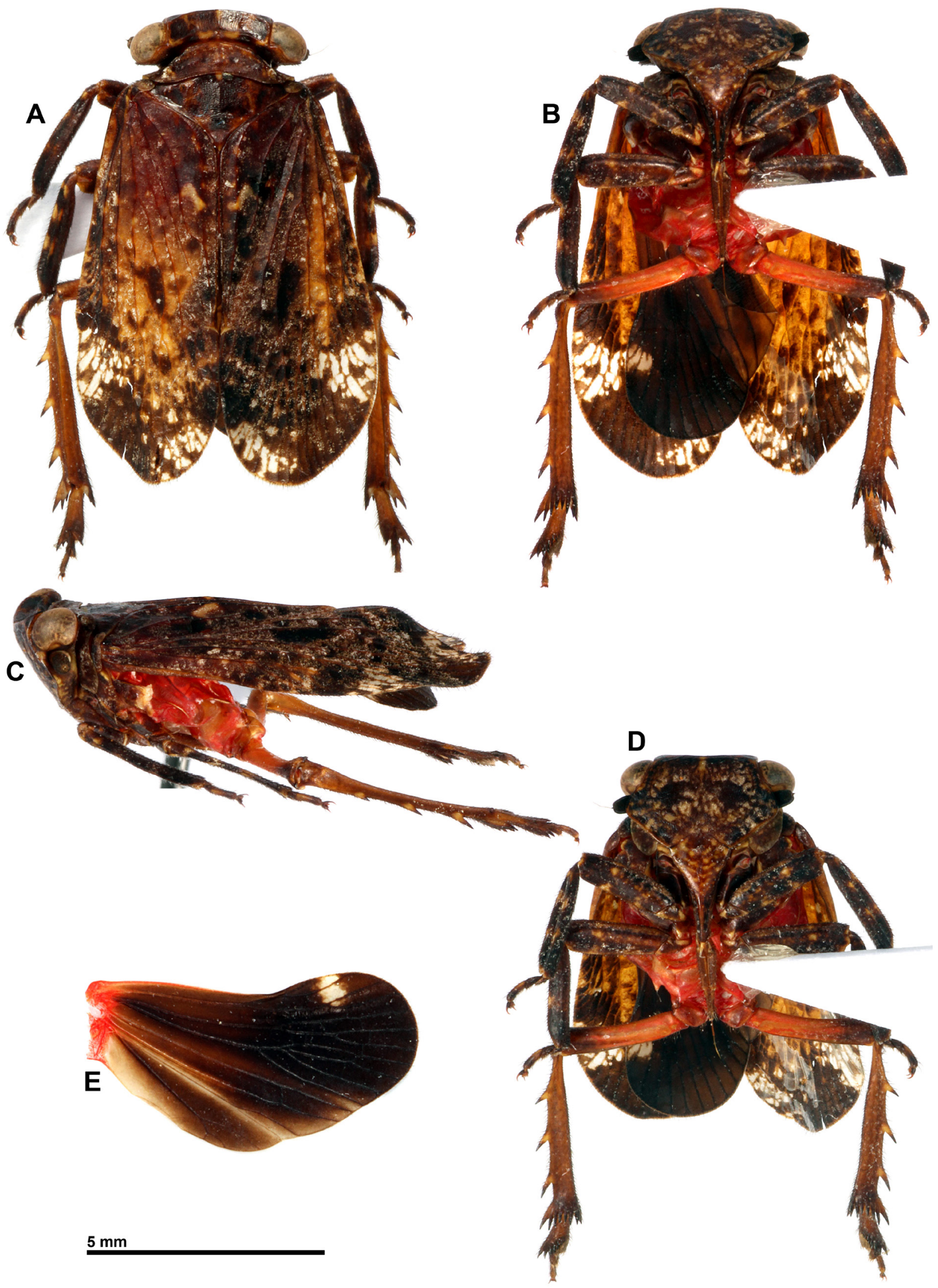

Fig. 7. Olonia danielsi sp. nov., holotype, ઊ̂. A. Habitus, dorsal view. B. Habitus, ventral view. C. Habitus, lateral view. D. Habitus, normal view of frons. E. Posterior wing. 

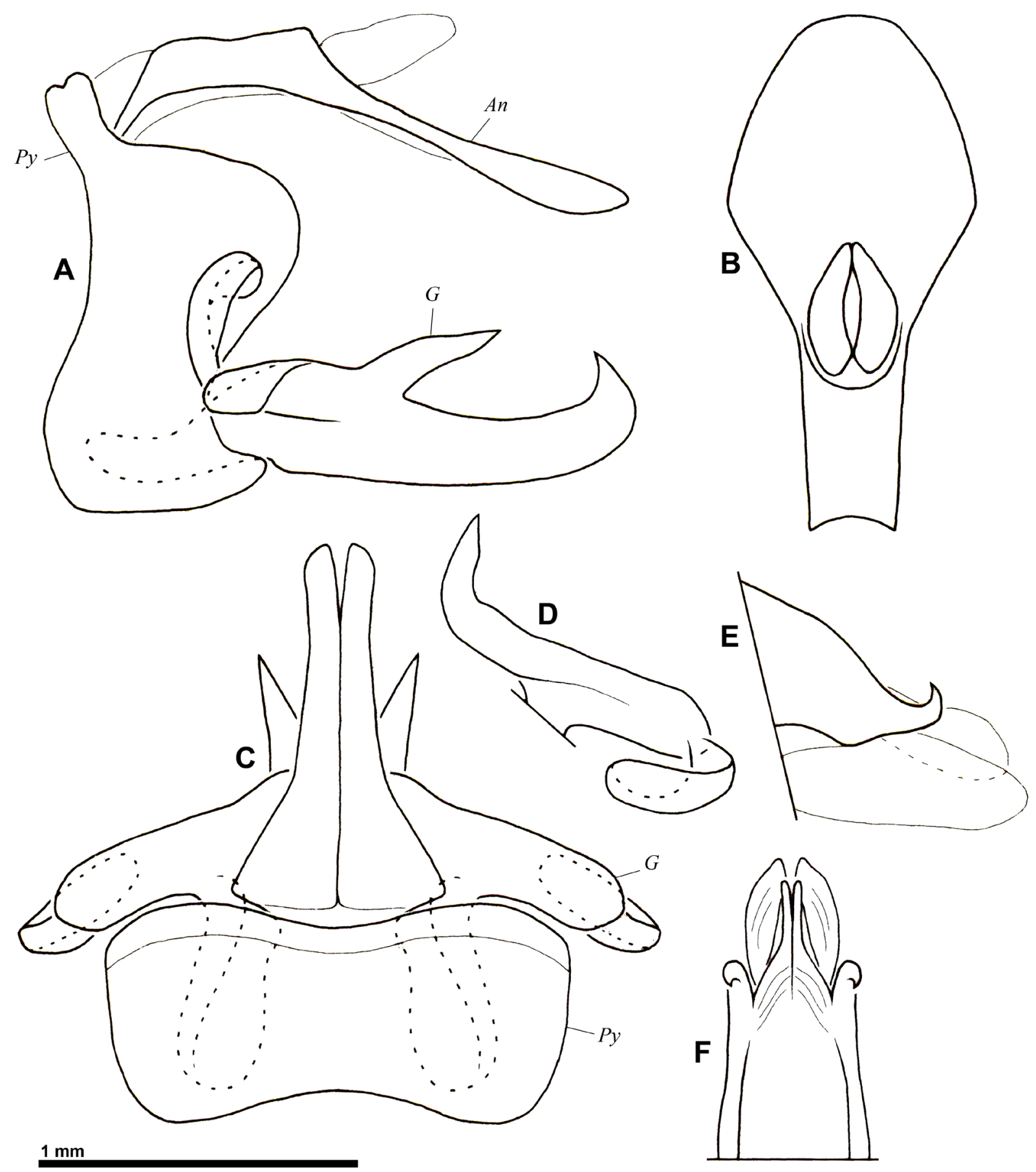

Fig. 8. Olonia danielsi sp. nov., holotype, ô, genitalia. A. Pygofer, anal tube and gonostyli, left lateral view. B. Anal tube, dorsal view. C. Pygofer and gonostyli, ventral view. D. Laterodorsal part of left gonostylus, dorsal view. E. Aedeagus, left lateral view. F. Aedeagus, dorsal view. Abbreviations: $A n=$ anal tube; $G=$ gonostyli; $P y=$ pygofer. 


\section{Olonia guillaumei sp. nov. urn:1sid:zoobank.org:act:26C5880F-0D15-409D-99C3-CA496382C6FE}

Figs 3, 9-11

\section{Diagnosis}

This species can be recognized by the following combination of characters:

(1) hind wings with conspicuous orange marking (Figs 9E, 11E)

(2) pro- and mesofemora and tibiae largely brown (Figs 9A-D, 11A-D)

(3) anal tube of male oblong, with posterior margin rounded (Fig. 10B)

(4) centroventral part of gonostyli with long laminate process (Fig. 10A, C)

(5) laterodorsal part of gonostyli with hooked process directed lateroventrally (Fig. 10A, C-D)

(6) rather large size: $9.5-10 \mathrm{~mm}$

\section{Etymology}

This species is named after my son, Guillaume.

\section{Type material}

\section{Holotype}

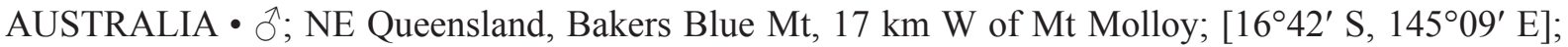
"N.E. QLD, Bakers Blue Mt, 17 km W Mt Molloy, 800m, open For. 12.ix.1981, G. Monteith \& D. Cook"; QM.

\section{Paratypes}

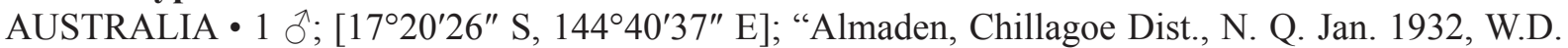
Campbell", "K64979"; AMS • 1 क; "Almaden, Chillagoe Dist., N. Q. March 1929, W.D. Campbell”, "K58965”; AMS • 1 गे; “Almaden, Chillagoe Dist., N. Q. June 1927, W.D. Campbell”, "K56631.”;

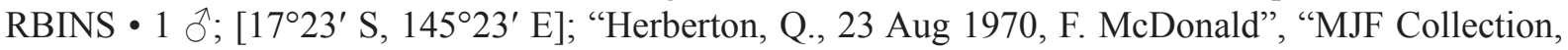
MJF003398"; ASCU.

\section{Description}

Measurements and ratios. LT: $\widehat{\jmath}(\mathrm{n}=3): 9.9 \mathrm{~mm}(9.6-10.1) ; \mathrm{BV} / \mathrm{LV}=4.15 ; \mathrm{BF} / \mathrm{LF}=1.83 ; \mathrm{LP}+\mathrm{LM} /$ $\mathrm{BT}=0.66 ; \mathrm{Ltg} / \mathrm{BTg}=2.5 ; \mathrm{LW} / \mathrm{BW}=1.80$.

\section{Male}

HEAD (Fig. 9A-D). Vertex concave with anterior and posterior margins parallel, curved; yellowish variegated with brown and with black marking at lateral angles. Frons black-brown with mediobasal irregular marking yellowish variegated with brown. Clypeus elongate, brown with 2 short, black, longitudinal lines at base, with oblique yellowish lines on sides and with apex darker. Genae pale yellowish, slightly darker at place around eyes and with brown marking under antennae. Labium blackbrown, reaching metacoxae. Antennae dark brown; scape short, ring-shaped; pedicel subcylindrical, slightly narrowing towards apex.

THORAX (Fig. 9A-D). Pronotum brown variegated with yellowish, with blackish marking and with yellowish spot at lateral angles; slightly transversely wrinkled posteriorly; obsolete median carina and 2 small impressed points on disc. Lateral fields of prothorax dark brown. Mesonotum black-brown with reddish markings along posterior margin, median yellowish spot along anterior margin and at apex of scutellum; slightly transversely wrinkled; median and peridiscal carinae weakly marked; median carina stopping before scutellum; slight impression before scutellum. Red ventrally. Tegulae brown.

TEGmina (Fig. 9A, C). Brown variegated with yellowish and black; irregular transverse row of whitish spots at basal $1 / 3$; large triangular white marking on costal margin on nodal line; white spot at apicosutural angle. Maximum breadth at nodal line; costal margin sinuate; apical margin obliquely rounded. 

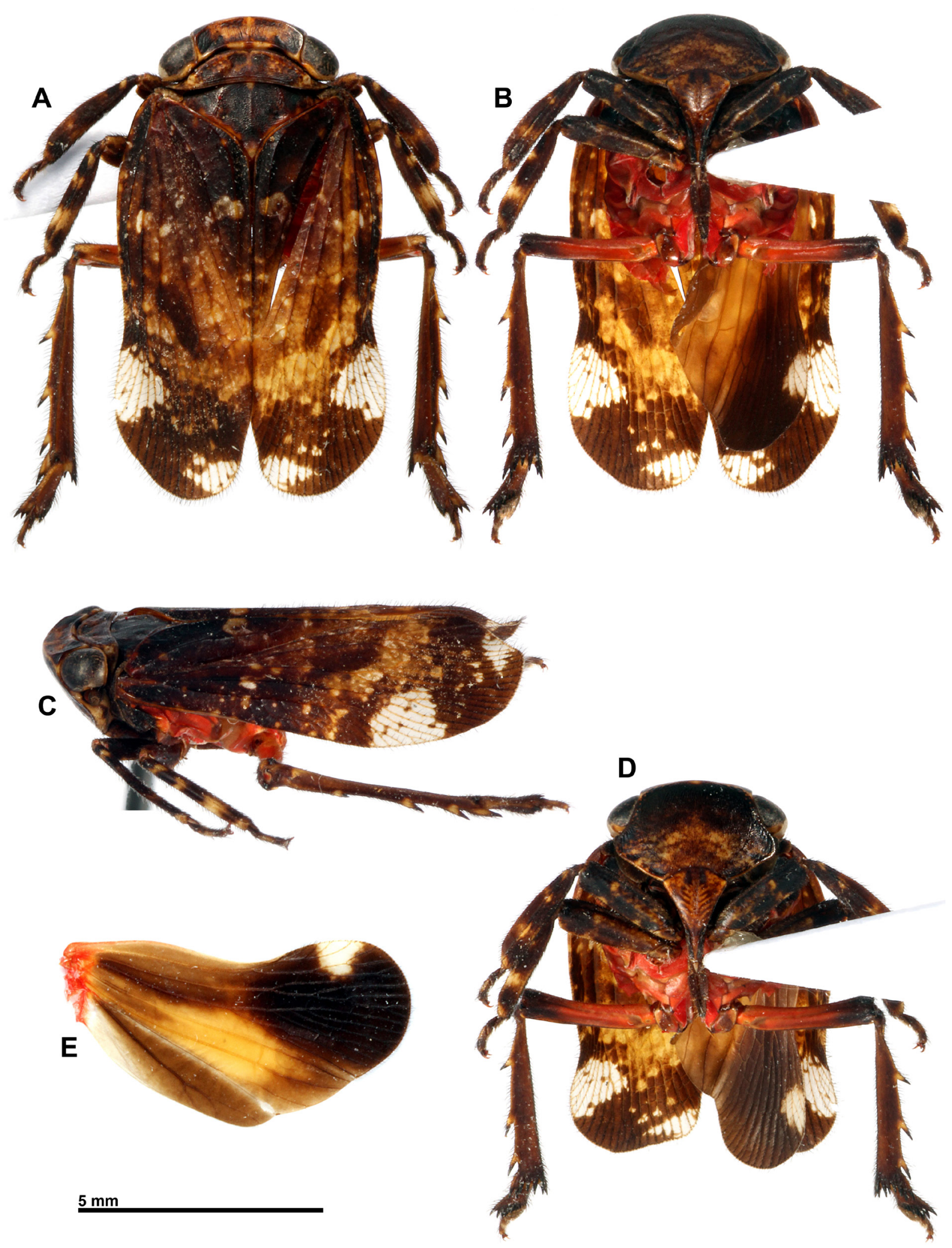

Fig. 9. Olonia guillaumei sp. nov., holotype, Ô. A. Habitus, dorsal view. B. Habitus, ventral view. C. Habitus, lateral view. D. Habitus, normal view of frons. E. Posterior wing. 


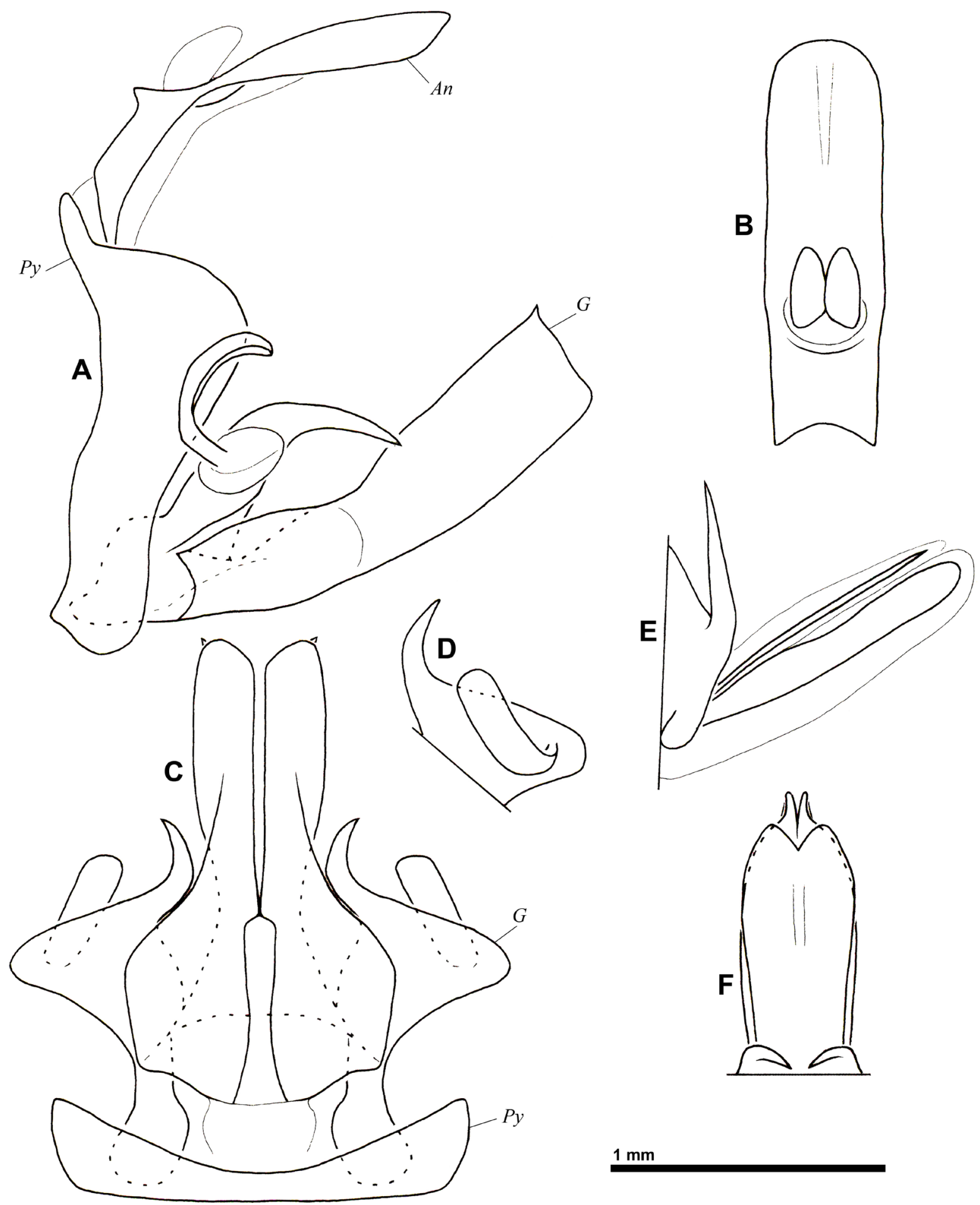

Fig. 10. Olonia guillaumei sp. nov., holotype, ô, genitalia. A. Pygofer, anal tube and gonostyli, left lateral view. B. Anal tube, dorsal view. C. Pygofer and gonostyli, ventral view. D. Laterodorsal part of left gonostylus, dorsal view. E. Aedeagus, left lateral view. F. Aedeagus, dorsal view. Abbreviations: $A n=$ anal tube; $G=$ gonostyli; $P y=$ pygofer. 

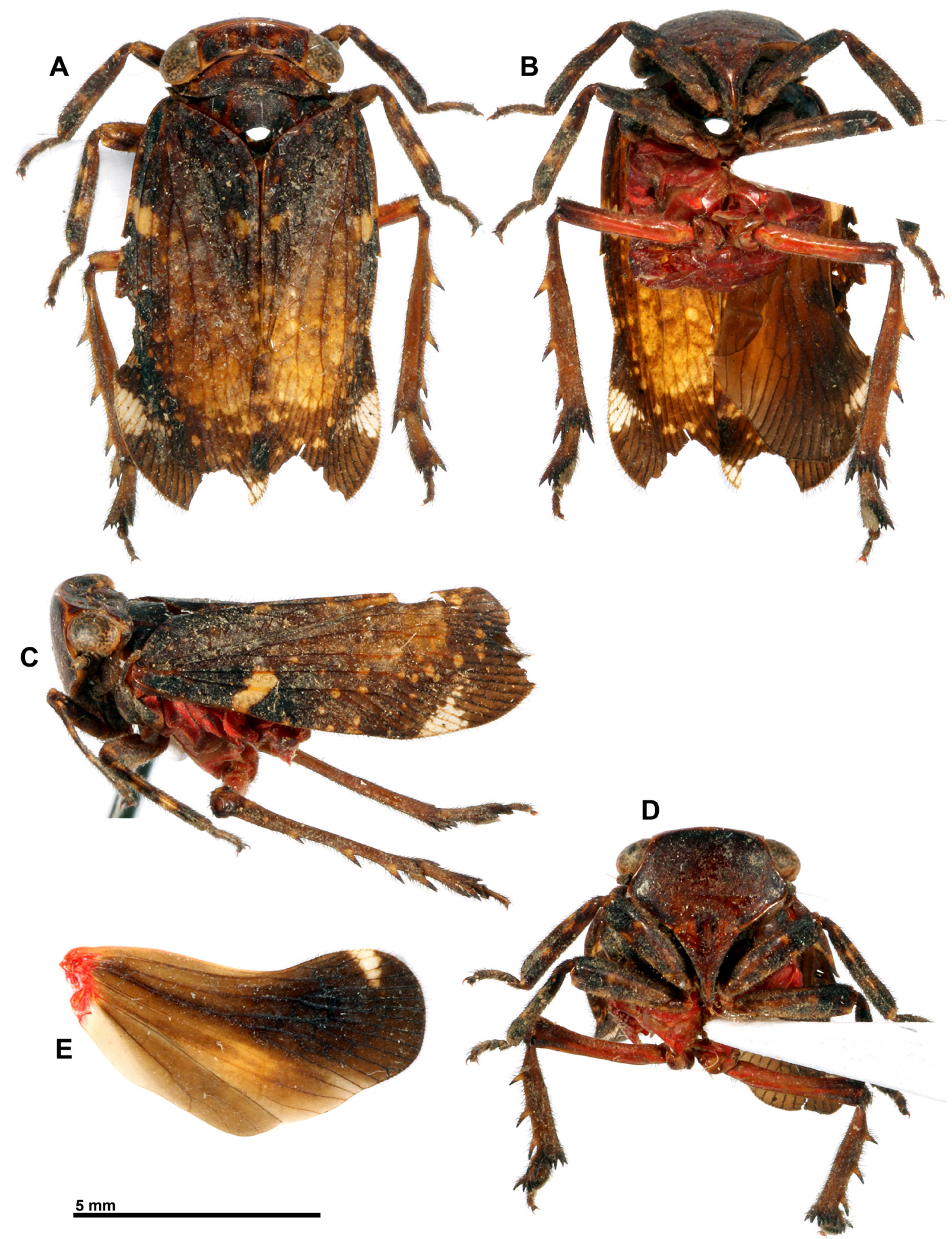

Fig. 11. Olonia guillaumei sp. nov., paratype, . . A. Habitus, dorsal view. B. Habitus, ventral view. C. Habitus, lateral view. D. Habitus, normal view of frons. E. Posterior wing. 
POSTERIOR wings (Fig. 9E). Brown with apical $1 / 3$ black; transverse, broad, subtriangular white marking at apicocostal angle, extending on 4 cells; large, elongate orange marking between anal fold and vein $\mathrm{CuA}$ at basal 1/3, not reaching margin. Margin of anal area slightly rounded; sutural margin with 2 clefts, cubital one slightly marked.

Legs (Fig. 9A-D). Pro- and mesocoxae brown. Pro- and mesofemora black-brown with 2 obsolete yellowish rings. Pro- and mesotibiae dark brown with 3 obsolete ring-shaped yellowish markings, larger one near apex. Pro- and mesotarsi dark brown with basal half of third tarsomere paler. Metacoxae reddish brown; metafemora red with apex dark brown. Metatibiae brown, with 3 lateral spines yellowish basally and 8 apical, black-brown spines. Metatarsi dark brown with a ventral row of 6 black spines on first tarsomere.

ABDomen. Bright red with genital segments black-brown.

MALE GENitAlia (Fig. 10). Posterior margin of pygofer in lateral view strongly sinuate, strongly roundly projecting at dorsal 1/3, narrow ventrally (Fig. 10A, C). Anal tube oblong, 3.3 times as long as broad, slightly curved ventrally in lateral view; lateral margins subparallel and slightly curved ventrally on apical $2 / 3$; apical margin rounded (Fig. 10A-B). Gonostyli fused to nearly half length of centroventral part and projecting posterodorsally (Fig. 10A, C). Centroventral part dorsoventrally flattened basally, progressively twisted and laminate towards apex, broader apically in lateral view, with apical margin slightly sinuate, apicodorsal angle pointed and apicoventral angle angularly rounded (Fig. 10A, C). Laterodorsal part of gonostyli curved lateroventrally, hooked, with lateral process rather broad and about as long as spoon-shaped process (Fig. 10A, C-D). Dorsal portion of phallobase with elongate process on each side, pointing dorsally and slightly internally (Fig. 10E-F). Ventral portion of phallobase along lateral margin of phallus on basal half, then under phallus, narrowing and bifid apically, directed posterodorsally (Fig. 10E-F). Phallus dorsoventrally flattened, elongate, with apical margin strongly emarginate in dorsal view (Fig. 10E-F).

\section{Female}

Similar to male, but with frons brown turning to reddish-brown medioventrally; legs paler with yellowish rings more developed; posterior wings less contrasted, with apicocostal white marking narrower and orange marking less developed (Fig. 11).

\section{Distribution and biology}

This species is currently recorded from a small area west of Mareeba in North Queensland (Fig. 3), in the Einasleigh Upland Savanna bioregion. The specimens were collected in January, March, June, August and November; hence, the species may be present all year long.

Olonia hochae sp. nov. urn:1sid:zoobank.org:act:AAD09D97-D6FD-438D-BBF4-CE7326D8AD08

Figs 3, 12-14

\section{Diagnosis}

This species can be recognized by the following combination of characters:

(1) hind wings without orange marking (Figs 12E, 14E)

(2) pro- and mesofemora and -tibiae largely black-brown (Figs 12A-D, 14A-D)

(3) anal tube of male oblong, with posterior margin narrowly rounded (Fig. 13B)

(4) centroventral part of gonostyli with long laminate process concave on ventral margin (Fig. 13A, C)

(5) laterodorsal part of gonostyli with spinose process curved ventrally (Fig. 13A, C-D)

(6) rather large size: $9-10 \mathrm{~mm}$ 


\section{Etymology}

This species is dedicated to Dr Hannelore Hoch, who collected the paratypes series together with Dr Manfred Asche. But ladies first!

\section{Type material}

\section{Holotype}

AUSTRALIA • ${ }^{\prime}$; Queensland, Undara National Park; $18^{\circ} 15^{\prime}$ S, $144^{\circ} 41^{\prime}$ E; “QLD: $18^{\circ} 15^{\prime} \mathrm{Sx} 144^{\circ} 41^{\prime} \mathrm{E}$, Undara NP, 17 ft Bore. 8 Dec 2002-8 Feb 2003, G. Monteith, vine scrub. fit intercept. 11252", "QMT244703"; QM.

\section{Paratypes}

AUSTRALIA • $4 \hat{\jmath} \hat{\jmath}, 4$,+ ; "Australia: Queensland, Undara Lava flow: betw. Mt. Garnet \& Mt. Surprise, Yarramulla Sta.: surface around Pinwill's Cave", "18.i.1989, Au 24, M. Asche \& H. Hoch"; ZMHB $\bullet 1$ ¡, 1 ; ; same collection data as for preceding; RBINS.

\section{Description}

Measurements AND Ratios. LT: $\hat{\jmath}(\mathrm{n}=4)$ : $9.7 \mathrm{~mm}(9.4-9.9)$; + $(\mathrm{n}=5): 10.4 \mathrm{~mm}(10.0-10.8)$; BV/LV = $3.9 ; \mathrm{BF} / \mathrm{LF}=1.75 ; \mathrm{LP}+\mathrm{LM} / \mathrm{BT}=0.68 ; \mathrm{Ltg} / \mathrm{BTg}=2.40-2.45 ; \mathrm{LW} / \mathrm{BW}=1.78$.

\section{Male}

HEAD (Fig. 12A-D). Vertex concave, with anterior and posterior margins parallel, curved; dark brown variegated with yellowish in middle. Frons black-brown, slightly tinged with reddish medioventrally. Clypeus elongate, black-brown with 2 short, black, longitudinal lines at base, with oblique reddish lines on sides and with apex darker. Genae brown with yellowish markings along anterior margin. Labium black, reaching metacoxae. Antennae black; scape short, ring-shaped; pedicel subcylindrical, slightly narrowing towards apex.

Thorax (Fig. 12A-D). Pronotum dark brown with some yellowish markings; slightly transversely wrinkled posteriorly; obsolete median carina and 2 small impressed points on disc. Lateral fields of prothorax dark brown. Mesonotum black-brown with reddish markings along posterior margin, median yellowish spot along anterior margin and at apex of scutellum; slightly wrinkled; median and peridiscal carinae weakly marked; median carina stopping before scutellum; slight impression before scutellum. Red ventrally. Tegulae brown.

Tegmina (Fig. 12A, C). Dark brown with small yellowish or reddish spots; bigger, yellowish, slightly transverse spot on middle of clavus; large triangular white marking on costal margin on nodal line; white spot at apicosutural angle. Maximum breadth at nodal line; costal margin slightly sinuate; apical margin obliquely rounded.

POSTERIOR WINGS (Fig. 12E). Brown with apical $1 \frac{1}{3}$ black-brown; transverse, broad, subtriangular white marking at apicocostal angle, extending on 6 cells. Margin of anal area sinuate; sutural margin with 2 clefts, cubital one slightly marked.

Legs (Fig. 12A-D). Pro- and mesocoxae dark brown. Pro- and mesofemora black-brown with reddish spots marking 2 obsolete rings. Pro- and mesotibiae black-brown with 3 obsolete ring-shaped reddish or yellowish markings, larger one near apex. Pro- and mesotarsi dark brown. Metacoxae reddish brown; metafemora red with apex dark brown. Metatibiae brown, with 3 lateral spines yellowish basally and 8 apical, black-brown spines. Metatarsi brown, with a ventral row of 6 black spines on first tarsomere.

Aвdomen. Bright red with genital segments black-brown. 
Male Genitalia (Fig. 13). Posterior margin of pygofer in lateral view strongly sinuate, strongly roundly projecting at dorsal 1/3, narrow ventrally (Fig. 13A, C). Anal tube oblong, 3.6 times as long as broad, slightly curved ventrally in lateral view; slightly constricted on basal $1 / 3$ and narrowing towards apex in dorsal view; lateral margins sinuate and slightly curved ventrally on apical $2 / 3$; apical margin narrowly rounded (Fig. 13A-B). Gonostyli fused to slightly further than basal third of centroventral part and projecting posterodorsally (Fig. 13A, C). Centroventral part dorsoventrally flattened basally,
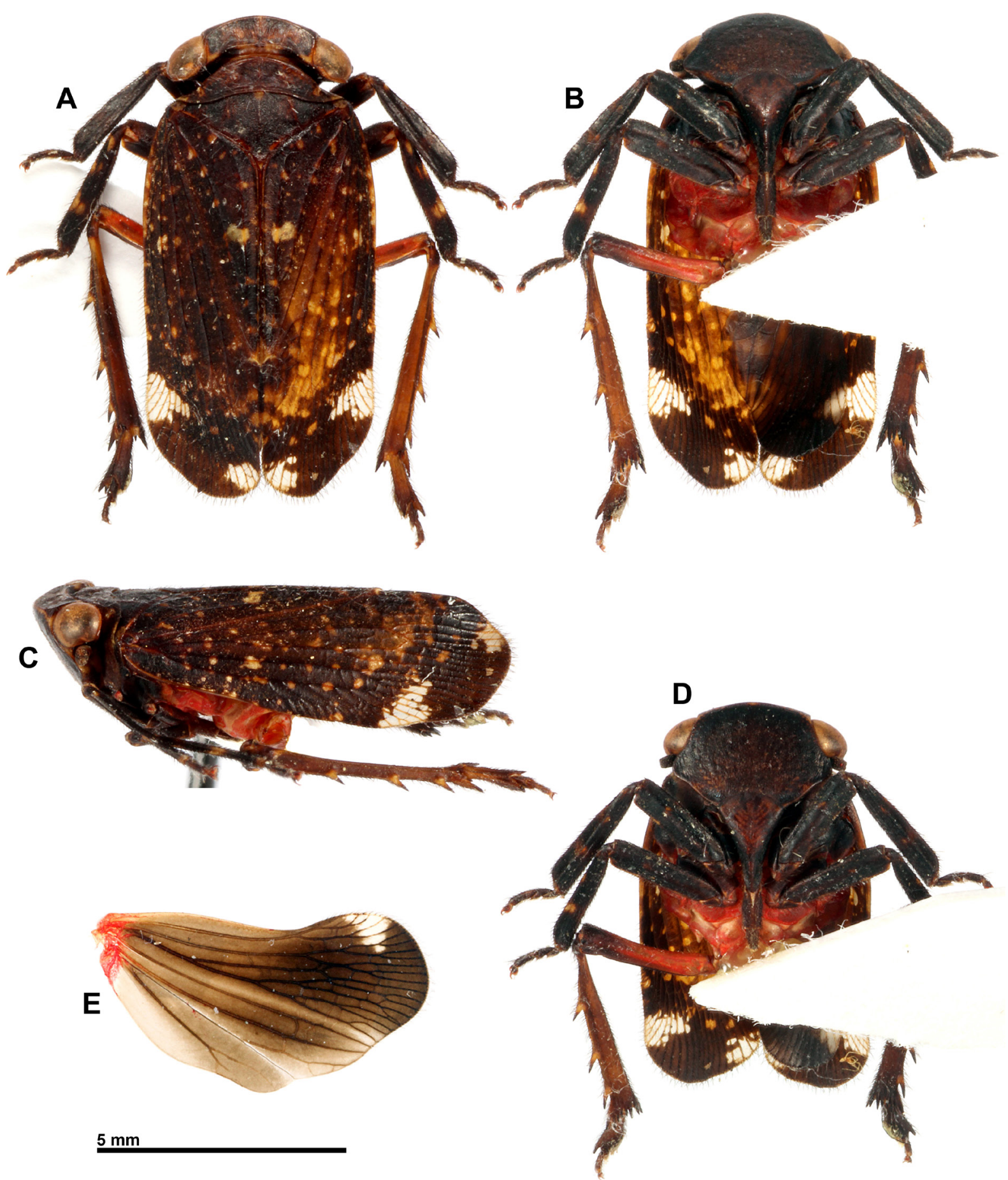

Fig. 12. Olonia hochae sp. nov., paratype, $\widehat{\jmath}$. A. Habitus, dorsal view. B. Habitus, ventral view. C. Habitus, lateral view. D. Habitus, normal view of frons. E. Posterior wing. 


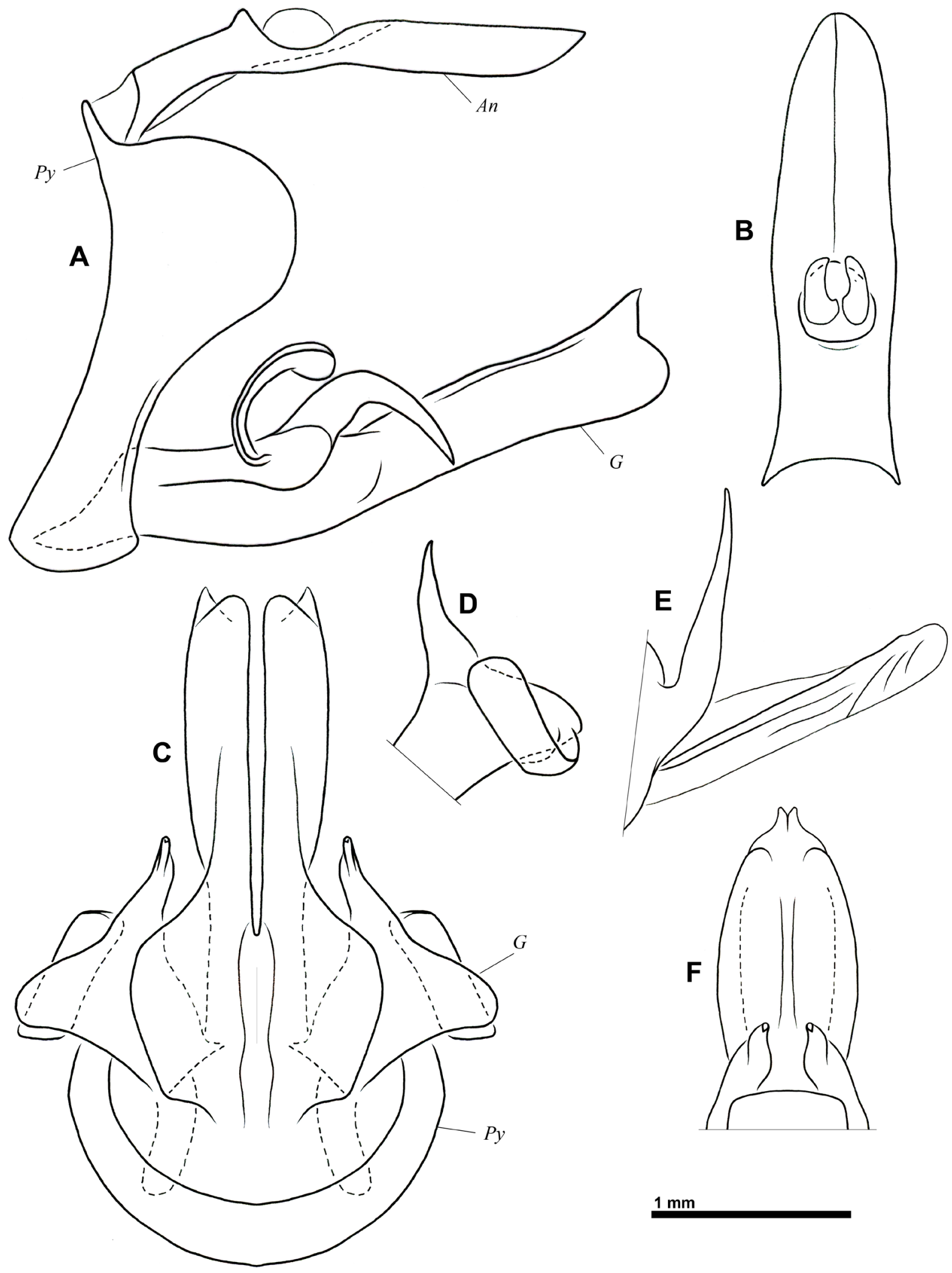

Fig. 13. Olonia hochae sp. nov., holotype, $\hat{\jmath}$, genitalia. A. Pygofer, anal tube and gonostyli, left lateral view. B. Anal tube, dorsal view. C. Pygofer and gonostyli, ventral view. D. Laterodorsal part of left gonostylus, dorsal view. E. Aedeagus, left lateral view. F. Aedeagus, dorsal view. Abbreviations: $A n=$ anal tube $G=$ gonostyli; $P y=$ pygofer. 
progressively twisted and laminate towards apex and with ventral margin concave in lateral view; slightly broader apically in lateral view with apical margin strongly sinuate, apicodorsal angle pointed and apicoventral angle rounded (Fig. 13A, C). Laterodorsal part of gonostyli with ventrally strongly curved, hooked process, with lateral process rather broad and about as long as spoon-shaped process (Fig. 13A, C-D). Dorsal portion of phallobase with strongly elongated process on each side, pointing dorsally and slightly internally (Fig. 13E-F). Ventral portion of phallobase along lateral margin of phallus on basal two thirds, then under phallus, narrowing and bifid apically, directed posterodorsally (Fig. 13E-F). Phallus dorsoventrally flattened, elongate, with apical margin emarginate in dorsal view (Fig. 13E-F).
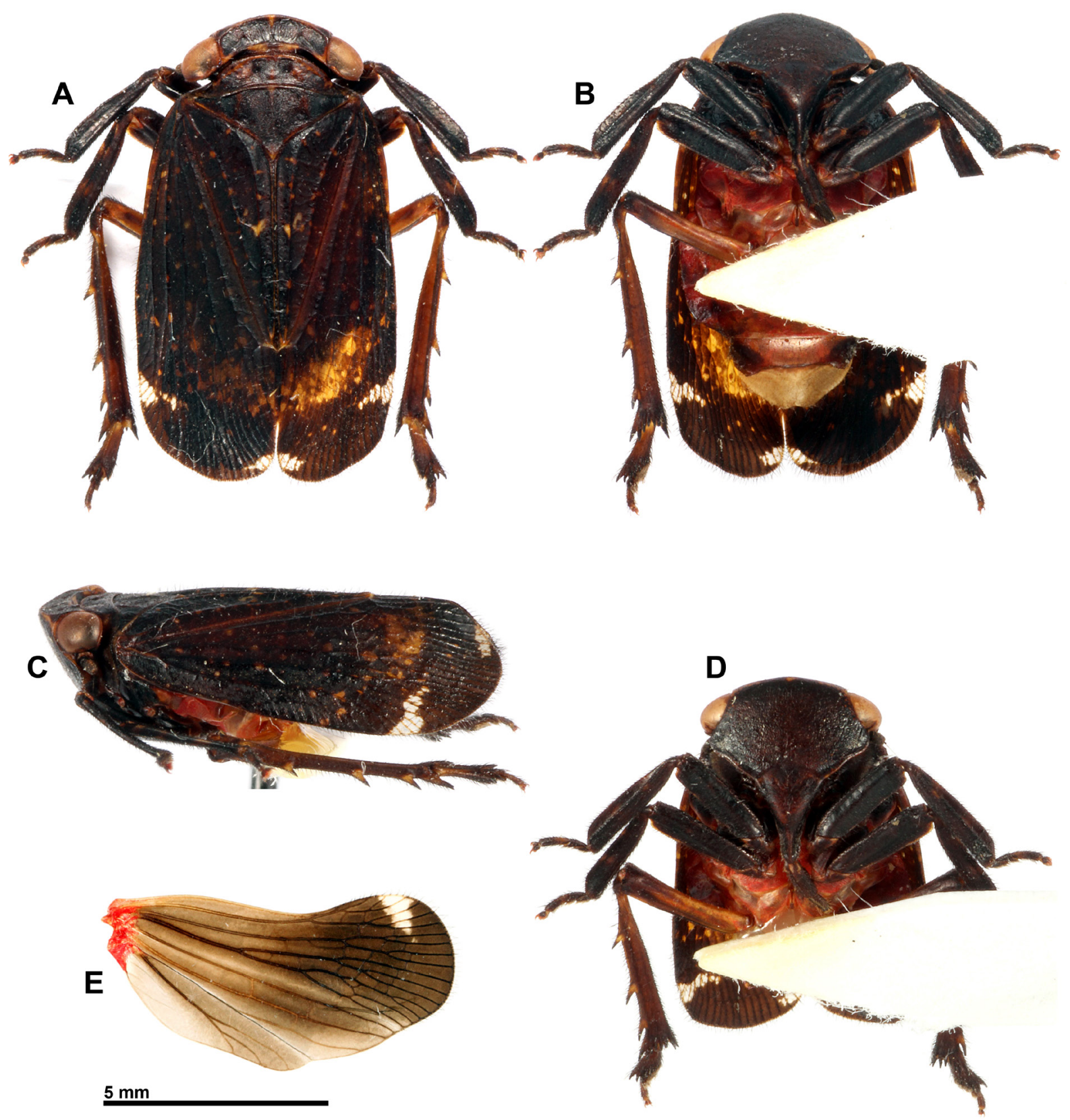

Fig. 14. Olonia hochae sp. nov., paratype, ․ A. Habitus, dorsal view. B. Habitus, ventral view. C. Habitus, lateral view. D. Habitus, normal view of frons. E. Posterior wing. 


\section{Female}

Similar to male, but darker; frons entirely black-brown; markings on pro- and mesofemora nearly absent; markings on pro- and mesotibiae reduced; white markings on tegmina smaller (Fig. 14).

\section{Distribution and biology}

This species is currently known from a series of ten specimens collected near Undara Lava Tubes in North Queensland (Fig. 3), in the Einasleigh Upland Savanna bioregion. All specimens were collected in January, on the same day; hence, the species is probably not scarce in its habitat.

Olonia marginata Distant, 1906

Figs 3, 15-25

Olonia marginata Distant, 1906: 206 (described).

Olonia marginata - Kirkaldy 1907: 105 (listed from Queensland). — Metcalf 1956: 64 (catalogued).

\section{Diagnosis}

This species can be recognized by the following combination of characters:

(1) hind wings without orange marking (Figs 16A, 20A)

(2) pro- and mesofemora and -tibiae largely black-brown (Figs 16A-D, 20A-D)

(3) anal tube of male spatulate, constricted at basal $1 \frac{1}{3}$ (Fig. 19B)

(4) centroventral part of gonostyli with narrow and strongly elongated process that is sinuate basally and hooked apically (Fig. 19A, C)

(5) laterodorsal part of gonostyli with narrow and strongly elongated process that is strongly curved posteroventrally (Fig. 19A, C-D)

(6) rather small size: $6-8 \mathrm{~mm}$

\section{Etymology}

The species epithet marginatus (adjective, Latin) means 'marginated', 'bordered'. It refers to the darkened costal and apical margins of the tegmina.

\section{Material examined}

\section{Lectotype}

AUSTRALIA • 1 O; Queensland; “Type”, "Type”, "Olonia marginata, type, Dist.”, "Queensland, F.P. Dodd, 1902 - 319"; here designated to provide a reference standard for this species; BMNH (Fig. 15).

\section{Paralectotypes}

AUSTRALIA • 2 우; “Queensland, F.P. Dodd, $1902-319 ” ;$ BMNH.

\section{Note}

In the collections of BMNH, there are 3 additional specimens identified by Distant but which are not part of the type series: 1 + , "Olonia marginata Dist.", "Townsville [19 $25^{\prime} 26^{\prime \prime} \mathrm{S}, 146^{\circ} 56^{\prime} 44^{\prime \prime}$ E] (Dodd)",

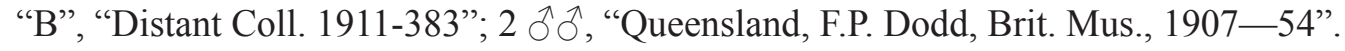

These specimens are particularly interesting because (1) they are from the same collector as the type series; (2) they provide Townsville as the location for the type series, where the collector, Frederick Parkhurst Dodd (1861-1937), lived at the time before moving to Kuranda and (3) there are two males, which allows a characterization of the species based on male genitalia. These males are used here as a reference for the recognition of this species. 


\section{Additional material}

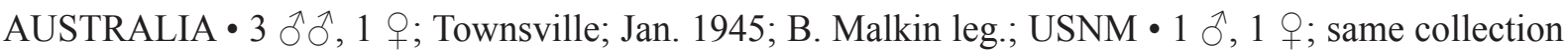

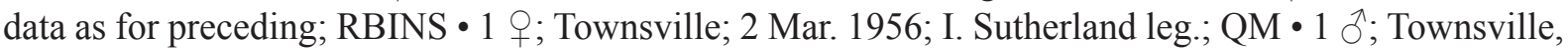
Hervey Range; 19²2'42" S, 146³1'29" E; 22 Sep. 1981; D.C. Geijskes leg.; RMNH・ 1 đ’; Townsville,

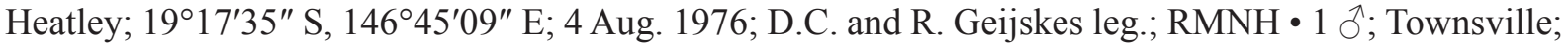

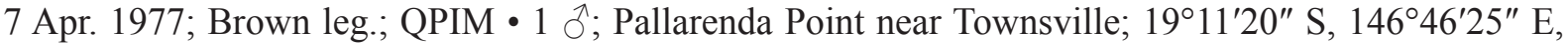
26 Jan. 1965; E.C. Dahms leg.; open forest, by net; QM • 1 §ं; Townsville, Hyde Park Shopping Centre; 19¹6'46" S, 14647'49" E; 25 Feb. 1992; L.M. Brown leg.; on Melaleuca quinquenervia; ASCU •

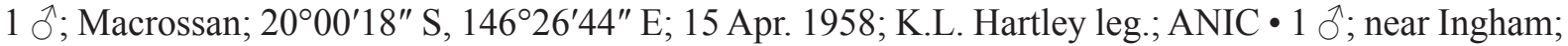

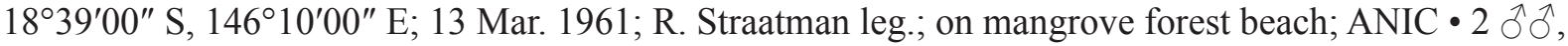
1 ; 10 mi. SSE of Collinsville [coordinates of Collinsville: 20³3'08" S, 147 50'38" E]; 14 Sep. 1950;

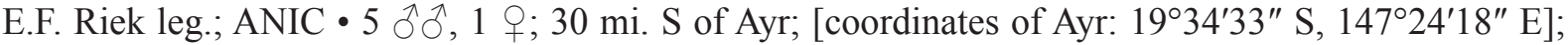

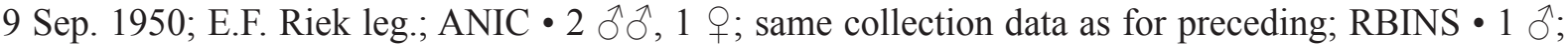
35 mi. SE of Ayr; 3 Oct. 1950; E.F. Riek leg.; ANIC • 1 क; 40 mi. SW of Ayr; 7 Oct. 1950; E.F. Riek leg.; ANIC • 1 q; 40 mi. S of Ayr; 10 Sep. 1950; E.F. Riek leg.; ANIC • 1 क; 50 mi. S of Ayr; 11 Sep. 1950; E.F. Riek leg.; ANIC 1 Oे; 35 mi. SW of Ayr; 6 Oct. 1950; E.F. Riek leg.; ANIC 1 o , 1 क; 60 mi. SW of Ayr; 8 Oct. 1950; E.F. Riek leg.; ANIC 1 त, 1 \%; same collection data as for preceding; RBINS • 1 q; 35 mi. NW of Bowen; [coordinates of Bowen: 2000'33" S, 148 $13^{\circ} 46^{\prime \prime}$ E]; 2 Oct. 1950;

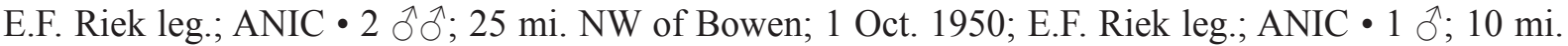
S of Bowen; 26 Sep. 1950; E.F. Riek leg.; ANIC • 4 우; Townsville; alt. sea level; 13 Jan. 1962; E.S. Ross and D.Q. Cavagnaro leg.; CAS • 1 \%; same collection data as for preceding; RBINS $\bullet 1$,

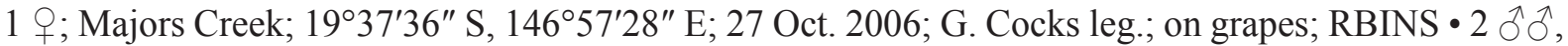
2 qo+; Townsville; 12 Oct. 1983; M.E. Irwin and E.I. Schlinger leg.; INHS • 1 ô, 1 q; same collection data as for preceding; RBINS • 1 ; $70 \mathrm{~km}$ NW of Townsville; 9 Nov. 1990; W.F. Chamberlain leg.; TAMU • 1 ô, 1 q; Rollingstone; 1902'40" S, 146²3'01" E; 19 Apr. 1998; L.J. Cookson leg.; MVMA

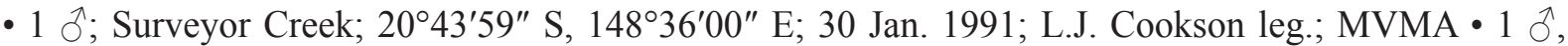

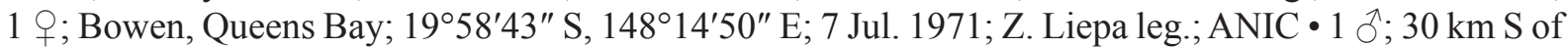

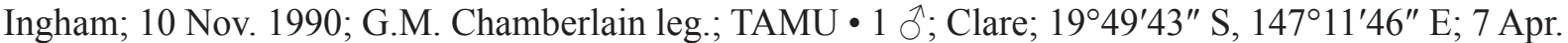
1951; W.A.S. leg.; from sweeping in jute; QDPI • 1 Oे; $^{\wedge}$ Saltwater Creek near Toomulla; $19^{\circ} 05^{\prime} 56.37^{\prime \prime}$ S, 146²7'46.69" E; 20 Apr. 1998; L.J. Cookson leg.; MVMA • 1 ô; 32 km S of Ayr; 6 Feb. 1964;

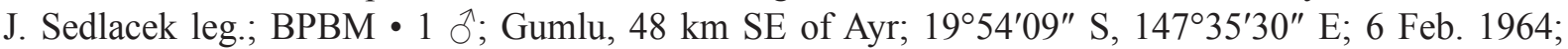
J. Sedlacek leg.; BPBM • 1 đ ; Herbert River; $18^{\circ} 31^{\prime} 59^{\prime \prime}$ S, $146^{\circ} 18^{\prime} 00^{\prime \prime}$ E; 1919; J.F. Illingworth leg.; on (sugar)cane; BPBM 1 O , 2 q $\circ$; Townsville, Strand Beach, Northern End; [coordinates of Strand Beach: 19²1'23" S, 146 48'24" E]; 15 Mar. 2016; V. Ryland leg.; on Ipomoea pes-caprae; RBINS • 2 오; same collection data as preceding; 19 Feb. 2016; QM • 1 q; same collection data as preceding; 25 Feb. 2016; QM 11 ' ; Townsville, port wall; [coordinates of Townsville port: $19^{\circ} 15^{\prime} 17^{\prime \prime} \mathrm{S}$, 146 50'11" E]; 15 Mar. 2016; V. Ryland leg.; on Ipomoea pes-caprae; RBINS • 1 '; Townsville, small boat harbour wall; [coordinates of Townsville small boat harbour: $19^{\circ} 15^{\prime} 12^{\prime \prime} \mathrm{S}, 146^{\circ} 49^{\prime 2} 24^{\prime \prime} \mathrm{E}$; 19 Mar. 2016; V. Ryland leg.; on Ipomoea pes-caprae; RBINS • 1 त; same collection data as for preceding;

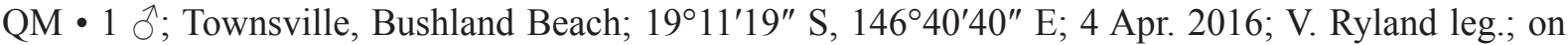

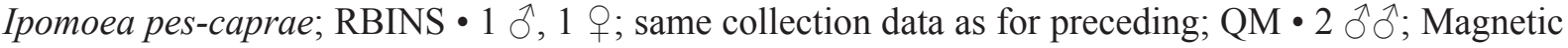
Island, Nelly Bay Beach; [coordinates of Nelly Bay: 1909'53" S, 146 51'01" E], 11 Feb. 2016; V. Ryland leg.; on Ipomoea pes-caprae; RBINS • 1 ภ, 1 क ; same collection data as for preceding; QM • 1 +; Magnetic Island, Geoffrey Bay Beach; [coordinates of Geoffrey Bay: 1909'17" S, 146 51'54" E]; 10 Feb. 2016; V. Ryland leg.; on Ipomoea pes-caprae; RBINS • 1 त; same collection data as for

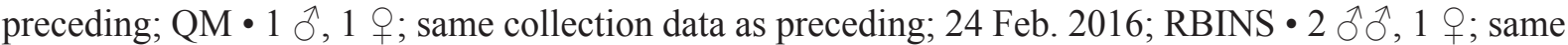
collection data as for preceding; QM $\bullet 1 \hat{0}, 1$; Magnetic Island, Picnic Bay Beach; [coordinates of Picnic Bay: 19¹0'54" S, 146 50'27" E]; 5 Feb. 2016; V. Ryland leg.; on Ipomoea pes-caprae; RBINS - 1 क ; same collection data as for preceding; QM 1 \%; same collection data as preceding; 12 Feb. 2016; RBINS • 1 \%; same collection data as preceding; 18 Feb. 2016; QM・1 \%; same collection data 


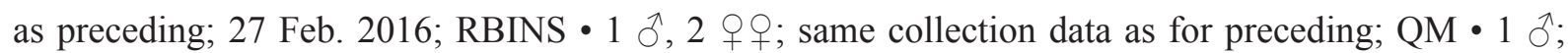
same collection data as preceding; 10 Jan. 2016; on Eucalyptus sapling; RBINS • 1 đ̧; Magnetic Island;

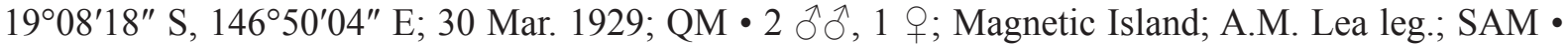
1 +; same collection data as preceding; G. F. Hill leg.; SAM • 1 ภ, 3 우우 ; Magnetic Island; 8 Nov. 2006; J. Constant leg.; on Canarium australianum sapling; RBINS • 1 q; Magnetic Island; 1914; Dr Scharff leg.; BMNH • 1 ơ; Alligator Creek; 19²3'56”'S 14655'36”E; 1 Apr. 1934; H. Hacker leg.; USNM •

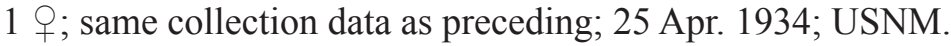

\section{Description}

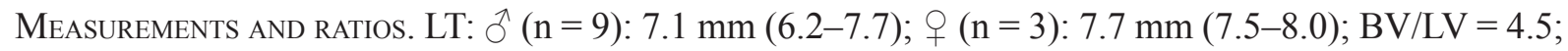
$\mathrm{BF} / \mathrm{LF}=1.68 ; \mathrm{LP}+\mathrm{LM} / \mathrm{BT}=0.68 ; \mathrm{Ltg} / \mathrm{BTg}=2.35 ; \mathrm{LW} / \mathrm{BW}=1.86$.

\section{Male}

HeAd (Figs 16A-D, 17A-D, 18A-D). Vertex concave, with anterior and posterior margins parallel, curved; brown with darker marking at lateral angles. Frons uniformly black-brown. Clypeus elongate, entirely black-brown. Genae black-brown with yellowish markings along anterior margin. Labium black, reaching metacoxae. Antennae black-brown; scape short, ring-shaped; pedicel subcylindrical, slightly narrowing towards apex.

Thorax (Figs 16A-D, 17A-D, 18A-D). Pronotum brown with small yellowish spot on each side; slightly wrinkled; obsolete median carina and 2 small impressed points on disc. Lateral fields of prothorax dark brown. Mesonotum brown variegated with blackish; yellowish spot on middle of anterior margin and at apex of scutellum; median and peridiscal carinae weakly marked; median carina stopping before scutellum; slight impression before scutellum. Red ventrally. Tegulae dark brown.

Tegmina (Figs 16A, C, 17A, C, 18A, C). Brown slightly variegated with yellowish and black; often pale yellowish marking on vein $\mathrm{A} 1$ at midlength of clavus; marked with black along costal margin, more broadly so on posterior half, and along posterior margin (Figs 16A, C, 17A, C); sometimes a broad, whitish, transverse band at proximal $1 / 3$, bordered with black markings along costal margin (Fig. 18A, C). Darker, median, irregular marking at apical $2 / 3$; triangular white marking on costal margin on nodal line, sometimes reduced; no white spot at apicosutural angle. Costal and sutural margins subparallel; costal margin slightly sinuate; apical margin obliquely rounded.

Posterior wings (Figs 16E, 17E, 18E). Dark brown, paler on anal area and with large blackish area reaching apical margin; elongate, transverse, subtriangular white marking at apicocostal angle, extending on 3-4 cells. Margin of anal area slightly sinuate; sutural margin with $1 \mathrm{cleft}$, cubital one not marked.

Legs (Figs 16A-D, 17A-D, 18A-D). Pro- and mesocoxae black-brown. Pro- and mesofemora blackbrown with reddish spots marking obsolete rings. Pro- and mesotibiae black-brown with reddish markings on 3 obsolete rings. Pro- and mesotarsi black-brown with basal half of third tarsomere paler. Metacoxae reddish; metafemora reddish with apex brown. Metatibiae brown, with 3 lateral spines paler basally and 8 apical black-brown spines. Metatarsi brown, with a ventral row of 6 black spines on first tarsomere.

ABDOMEN (Fig. 18F). Bright red with genital segments black-brown.

MALE GENitAliA (Fig. 19). Posterior margin of pygofer in lateral view strongly sinuate, strongly roundly projecting at dorsal $1 / 3$, rather broad ventrally (Fig. 19A, C). Anal tube spatulate, 2.2 times as long as broad, laterally constricted at level of epiproct, slightly curved ventrally in lateral view; lateral margins slightly curved ventrally on apical 2/3; apical margin rounded (Fig. 19 A-B). Gonostyli fused on basal 


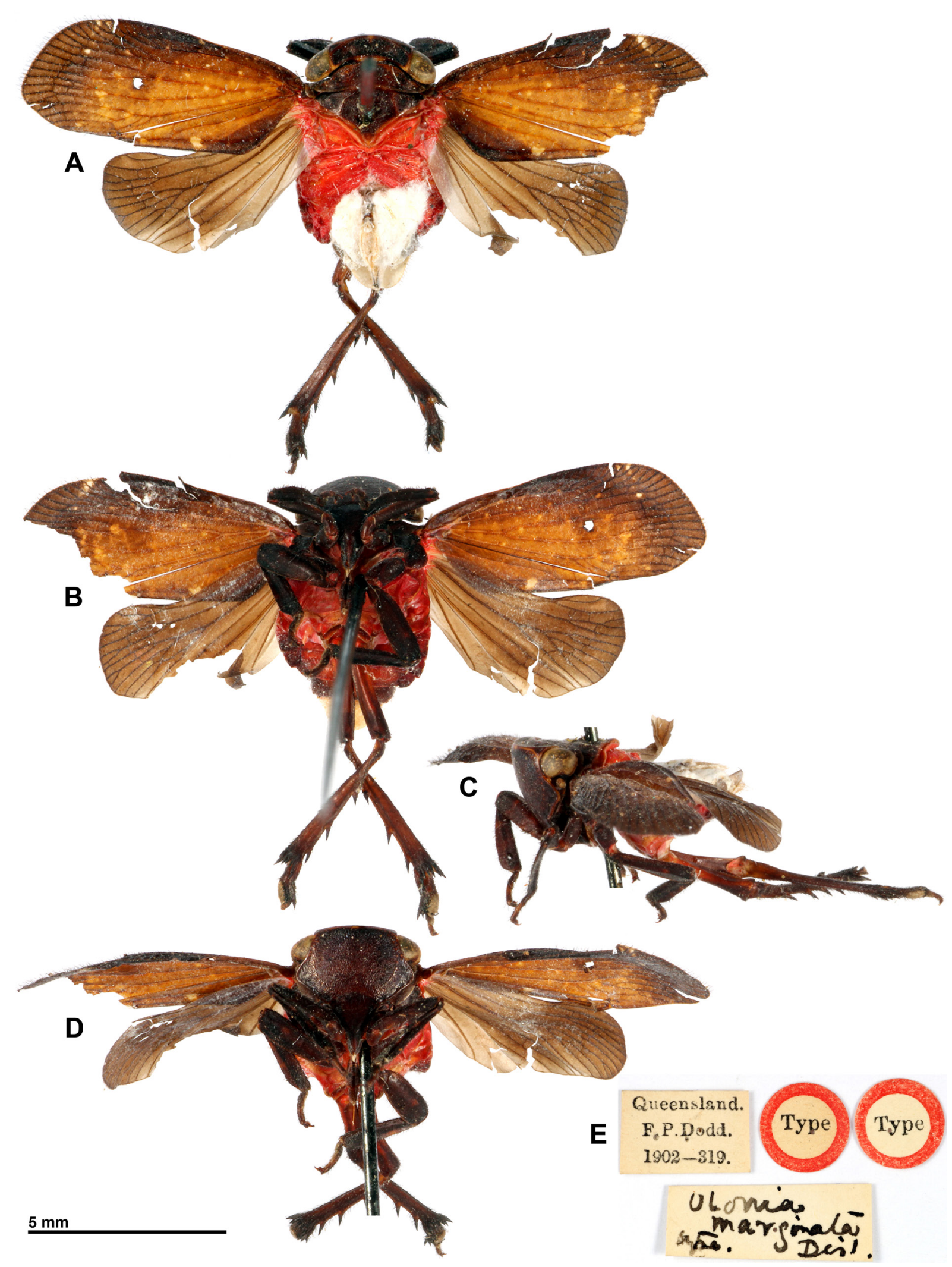

Fig. 15. Olonia marginata Distant, 1906, lectotype,, . A. Habitus, dorsal view. B. Habitus, ventral view. C. Habitus, lateral view. D. Habitus, normal view of frons. E. Labels. 

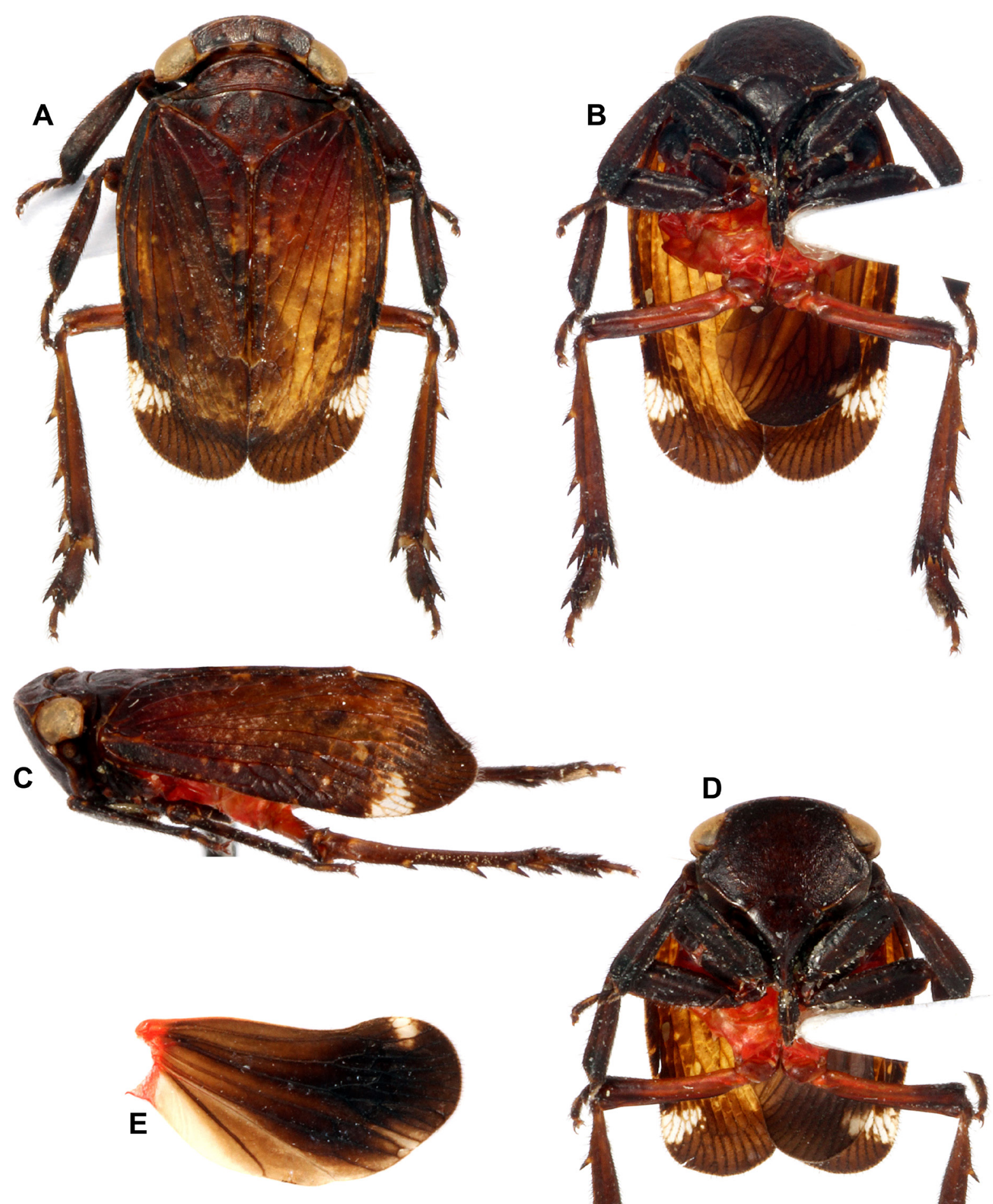

\section{$5 \mathrm{~mm}$}

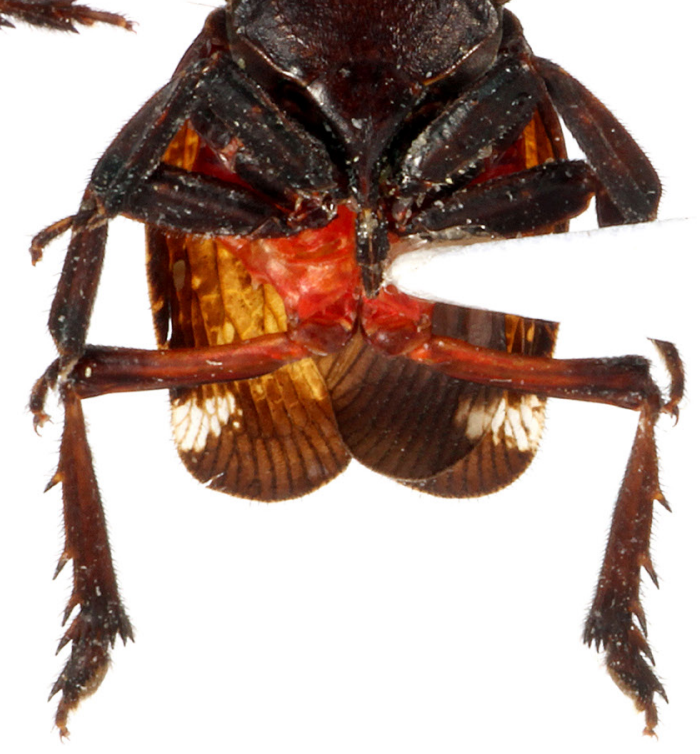

Fig. 16. Olonia marginata Distant, 1906, §̂ from mainland. A. Habitus, dorsal view. B. Habitus, ventral view. C. Habitus, lateral view. D. Habitus, normal view of frons. E. Posterior wing. 

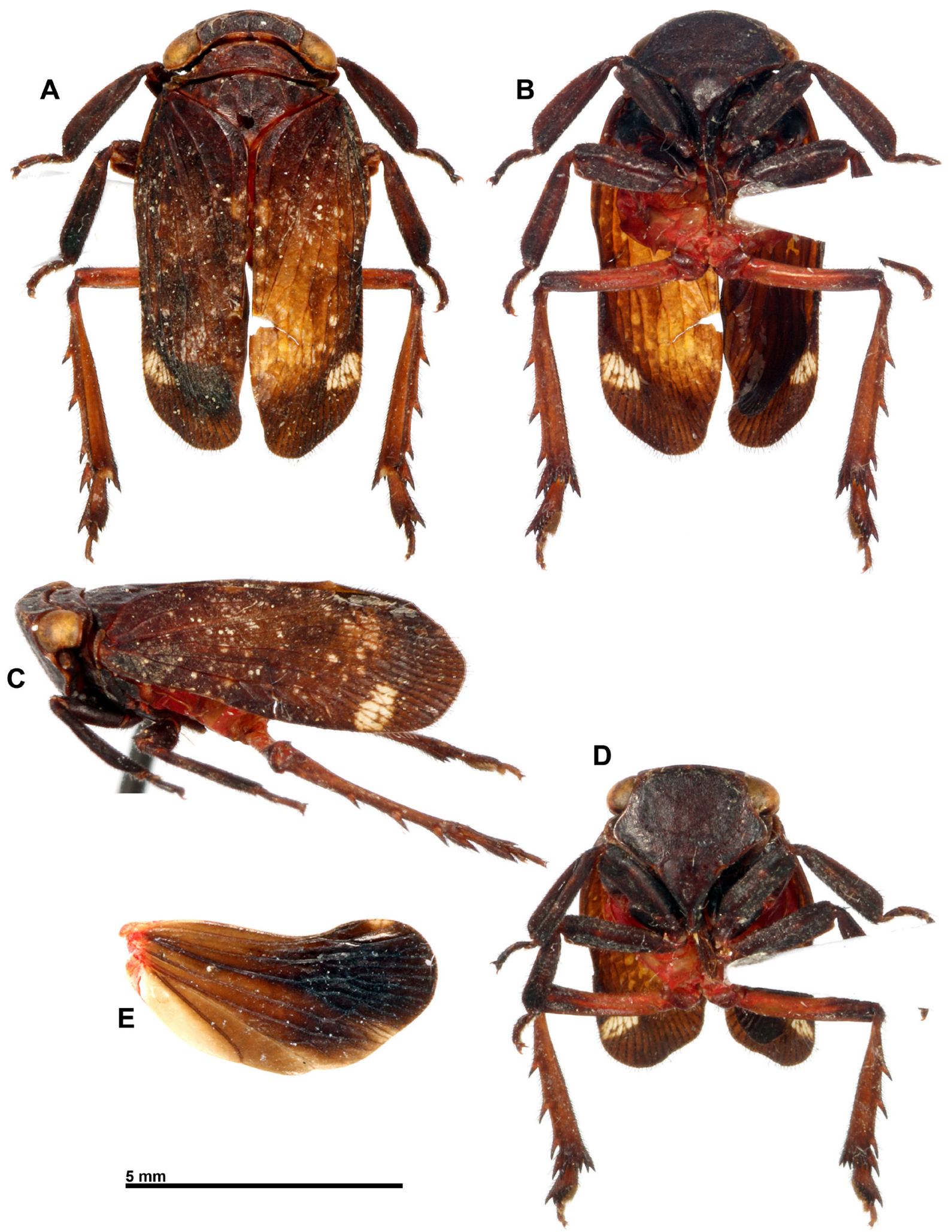

Fig. 17. Olonia marginata Distant, 1906, dark form, $\widehat{\partial}$ from Magnetic Island. A. Habitus, dorsal view. B. Habitus, ventral view. C. Habitus, lateral view. D. Habitus, normal view of frons. E. Posterior wing. 
third of length of centroventral part and projecting posteriorly (Fig. 19A, C). Centroventral part broad and dorsoventrally flattened on basal third, then strongly narrowing into a long spinose process strongly sinuate basally in lateral view and ending in narrow hook curved ventrally (Fig. 19A, C). Laterodorsal part of gonostyli strongly elongate and curved posteroventrally, surpassing level of centroventral part
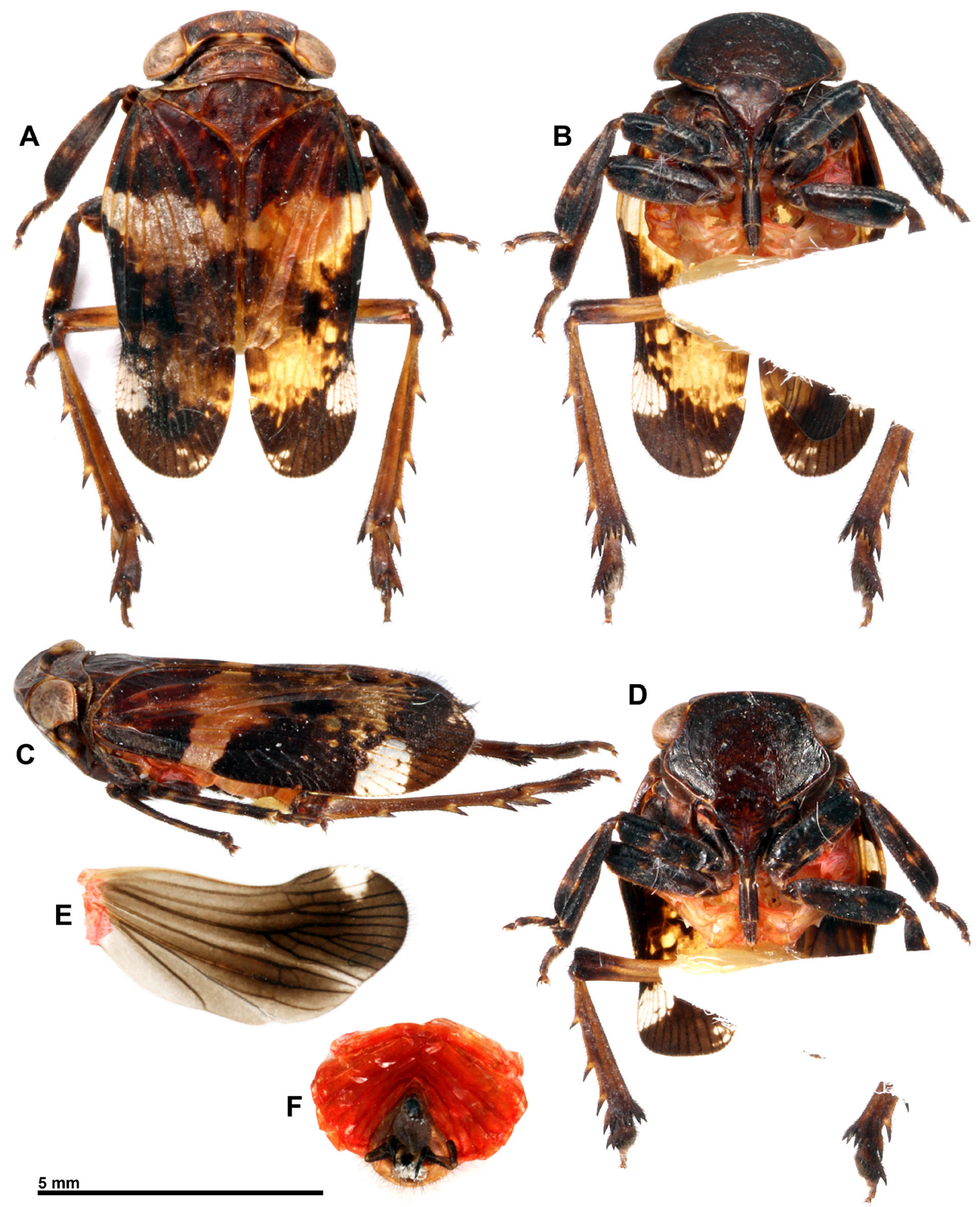

Fig. 18. Olonia marginata Distant, 1906, form with pale bands, $\widehat{o}$ from Magnetic Island. A. Habitus, dorsal view. B. Habitus, ventral view. C. Habitus, lateral view. D. Habitus, normal view of frons. E. Posterior wing. F. Abdomen, dorsal view. 
ventrally; lateral process elongate, projecting laterally and longer than spoon-shaped process (Fig. 19A, $\mathrm{C}-\mathrm{D})$. Dorsal portion of phallobase with hooked process on each side, progressively narrowing from base to apex, directed posterocentrally and with apex pointing dorsally (Fig. 19E-F). Ventral portion of phallobase trilobed in dorsal view, with median lobe surpassing phallus (Fig. 19E-F). Phallus dorsoventrally flattened, rather broad, with apical margin emarginate in middle (Fig. 19E-F).

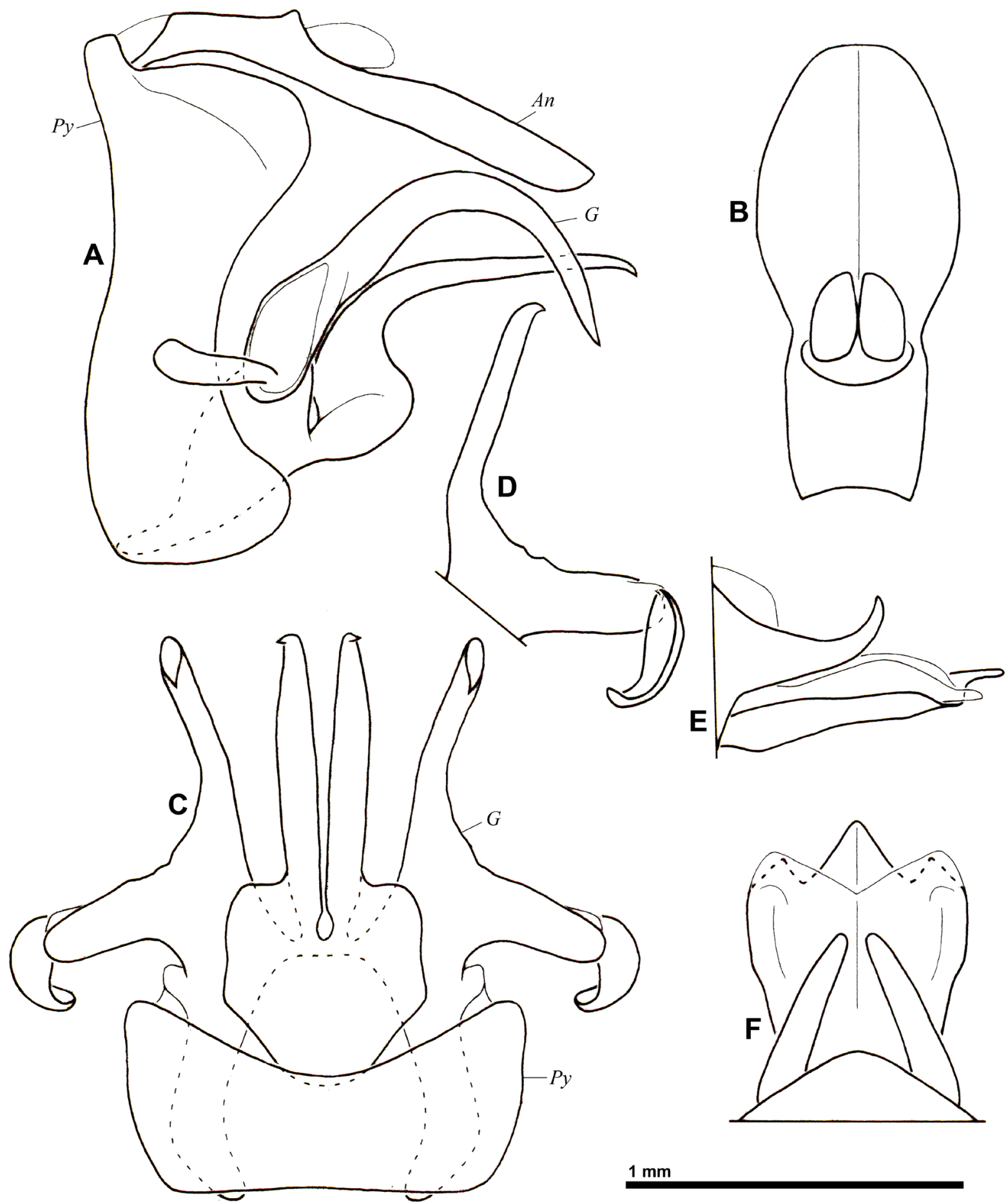

Fig. 19. Olonia marginata Distant, 1906, $\widehat{\jmath}$, genitalia. A. Pygofer, anal tube and gonostyli, left lateral view. B. Anal tube, dorsal view. C. Pygofer and gonostyli, ventral view. D. Laterodorsal part of left gonostylus, dorsal view. E. Aedeagus, left lateral view. F. Aedeagus, dorsal view. Abbreviations: $A n=$ anal tube; $G=$ gonostyli; $P y=$ pygofer. 

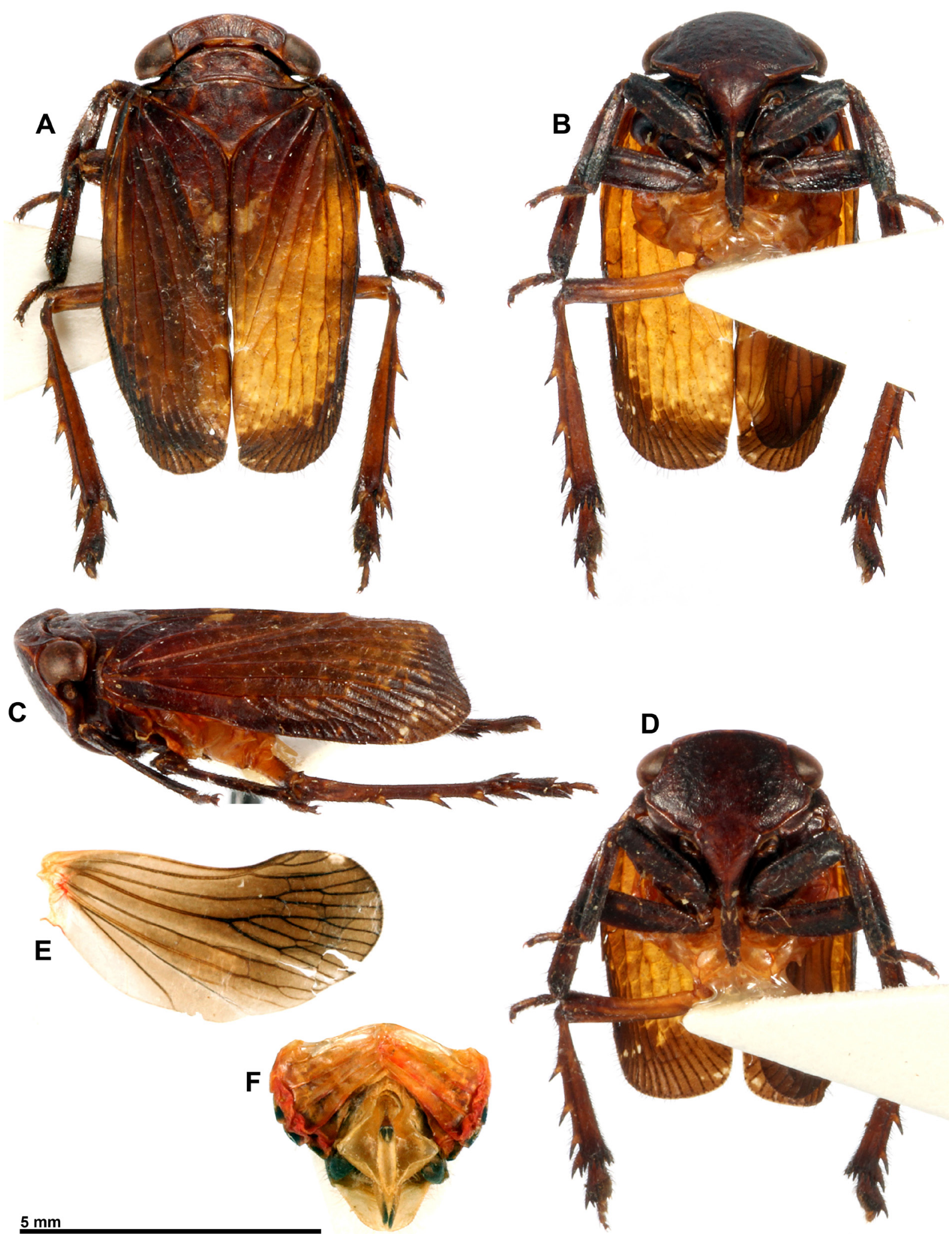

Fig. 20. Olonia marginata Distant, 1906, 9 from mainland. A. Habitus, dorsal view. B. Habitus, ventral view. C. Habitus, lateral view. D. Habitus, normal view of frons. E. Posterior wing. F. Abdomen, dorsal view. 

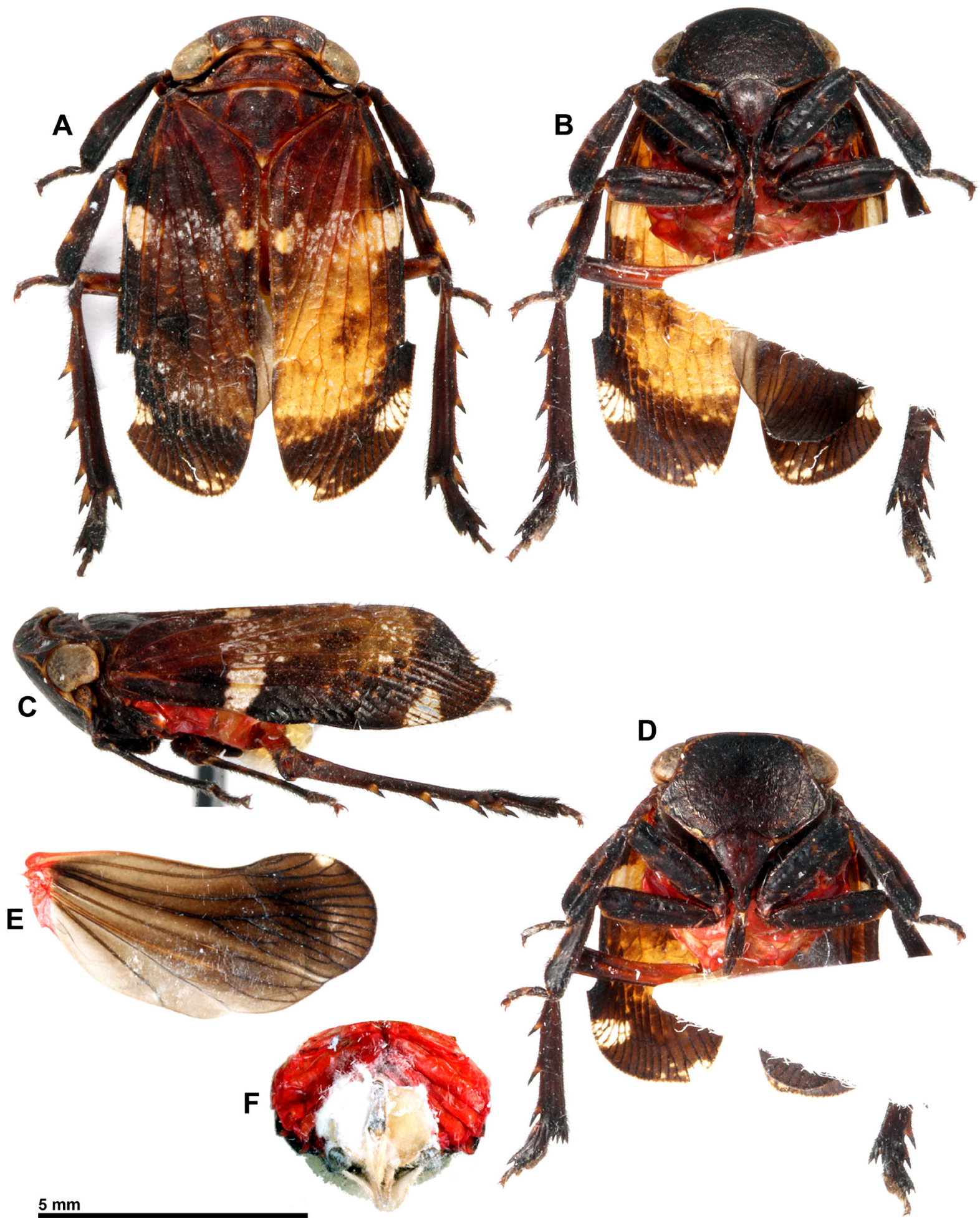

Fig. 21. Olonia marginata Distant, 1906, o from Magnetic Island. A. Habitus, dorsal view. B. Habitus, ventral view. C. Habitus, lateral view. D. Habitus, normal view of frons. E. Posterior wing. F. Abdomen, dorsal view. 


\section{Female}

Similar to male, but with white spot at apicosutural angle of posterior wing reduced, extending on 1 cell (Figs 15, 20). Sometimes with a reduced white transverse band at basal $1 / 3$ of tegmina visible in a marking along costal and sutural margins (Fig. 21).

\section{Nymph}

HeAD (Fig. 22). Brown, as broad as pronotum, frons flattened, with lateral rounded row of yellowish tubercles; group of yellowish tubercles dorsally on each side of joint between frons and vertex; clypeus reaching mesocoxae.

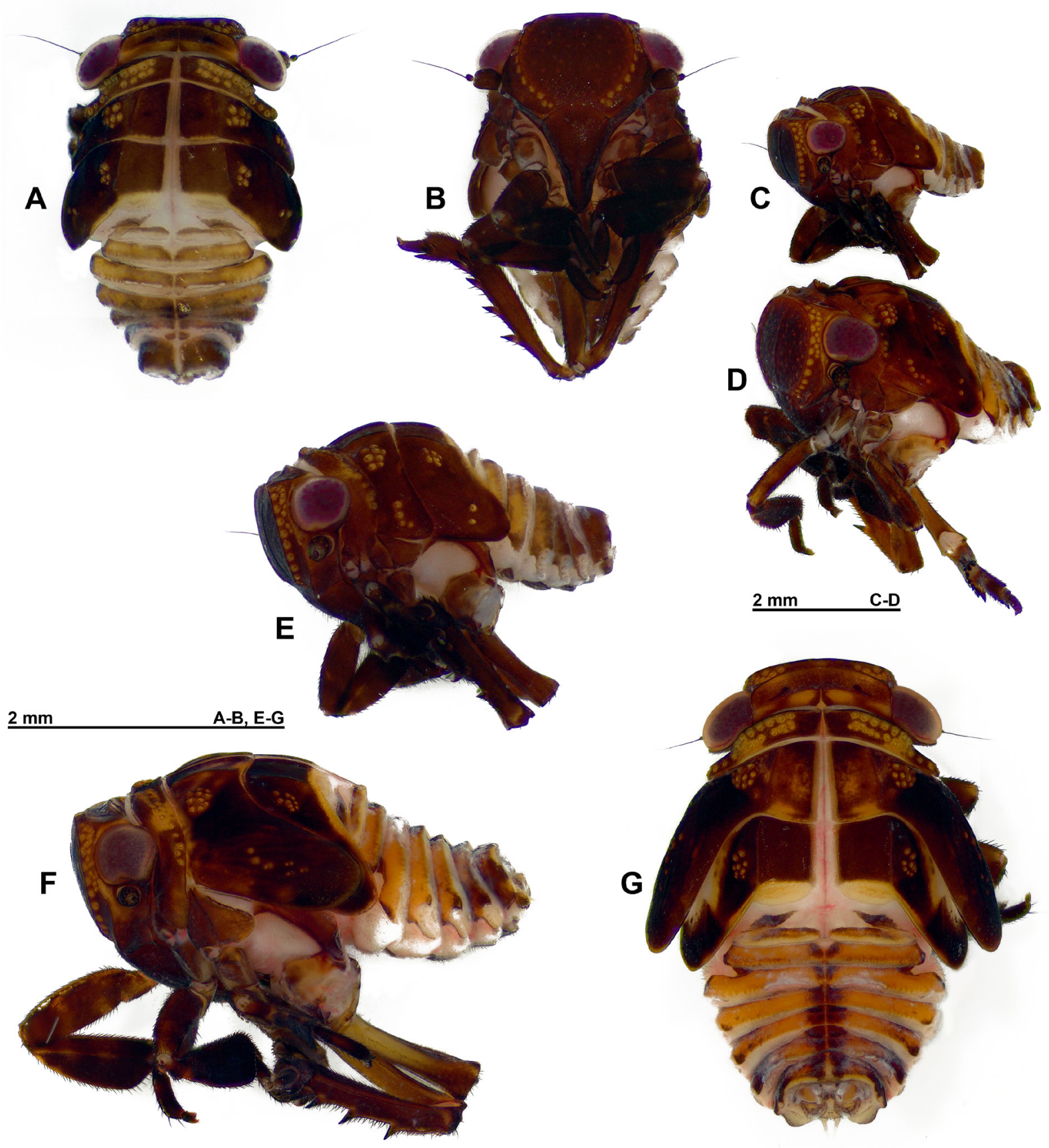

Fig. 22. Olonia marginata Distant, 1906, nymphs from Townsville, Bushland Beach, 4 Apr. 2016. A-E. Fourth instar nymphs. A. Dorsal view. B. Ventral view. C-E. Lateral view. F-G. Fifth instar nymph. F. Lateral view. G. Dorsal view. 
THorax (Fig. 22). Brown; pronotum short, with two dense rows of yellowish tubercles on each side; meso- and metanotum with a circular group of yellowish tubercles at base of wing buds and some tubercles near apex of wing buds.

LEGS (Fig. 22). Brown slightly variegated with yellowish; large in comparison to body size. Anterior and median femora and tibiae broad and dorsoventrally flattened; posterior tibiae with three strong lateral spines.

Aвdomen (Fig. 22). Rather short, less than half as long as head and thorax combined, and narrower than thorax; pale yellowish bown with dorsal median line and apex darker. Live specimens with abdomen

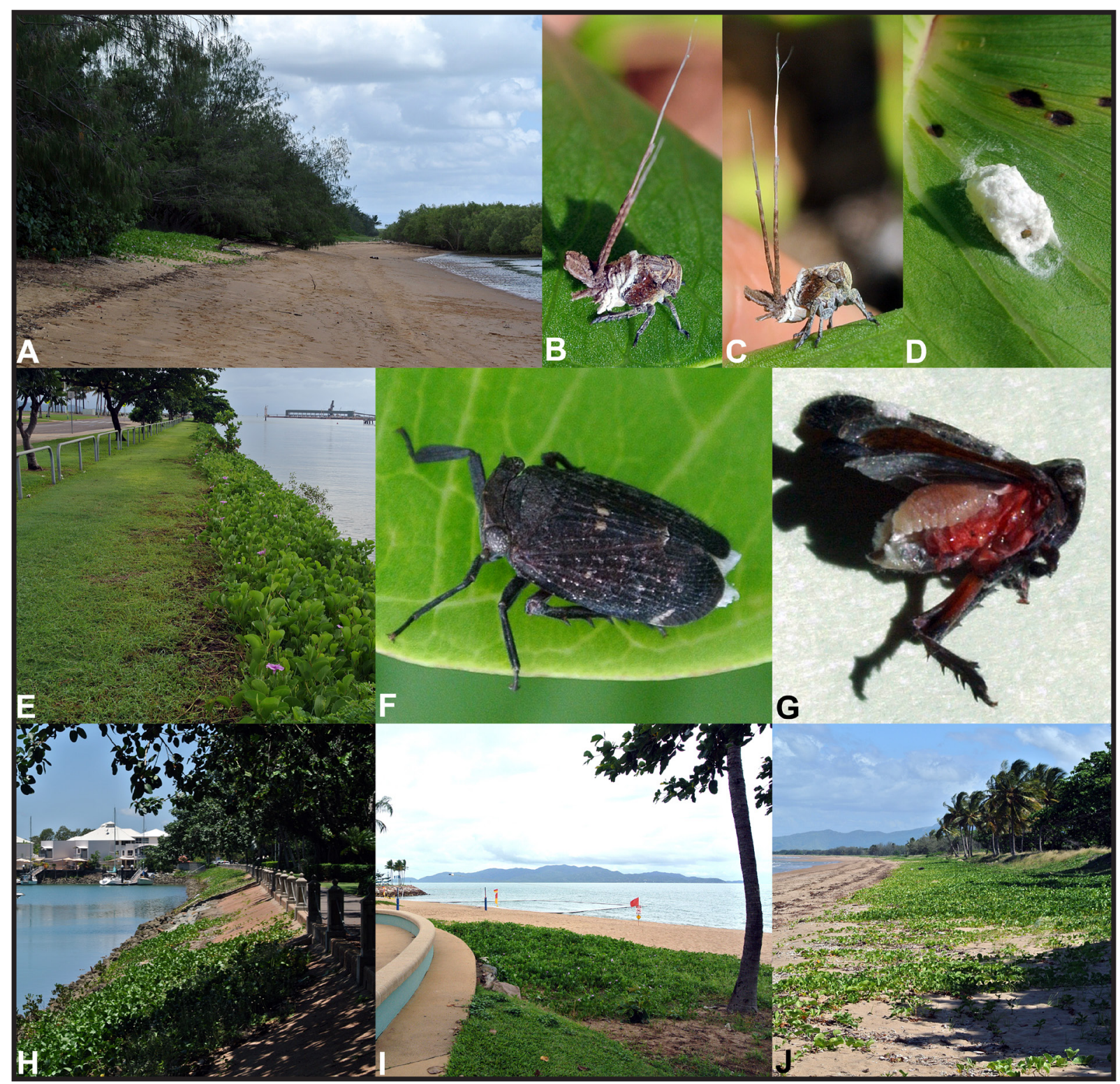

Fig. 23. Olonia marginata Distant, 1906, in nature, Townsville. A-C. Bushland Beach, 4 Apr. 2016. A. Habitat. B-C. Nymph on Ipomoea pes-caprae (L.) R.Br. D. Egg case on Ipomoea pes-caprae, Rowes Bay Beach, 25 Feb. 2016. E-F. Townsville Port Wall, 15 Mar. 2016. E. Habitat. F. Female on Ipomoea pes-caprae. G. Female parasitized by larva of Epipyropidae (Lepidoptera), Rowes Bay Beach, 26 Feb. 2016. H. Habitat, Small Boat Harbour, 19 Feb. 2016. I. Habitat, Strand Beach, 15 Mar. 2016. J. Habitat, Pallarenda Beach, 25 Feb. 2016. Photographs by V. Ryland. 
covered in white wax, except three apical segments with brown wax; each segment bearing a waxy plate on each side; two movable, very elongate, waxy filaments at apex of abdomen (Figs 23B-C, 25B-C, K, $\mathrm{N})$.

\section{Distribution and biology}

This species is recorded from an area around Townsville in North Queensland (Fig. 3), in the Einasleigh Upland Savanna, Queensland Tropical Rainforests and Brigalow Tropical Savanna bioregions. Adult specimens were collected in January, February, March, April, August, Sepember and October, while

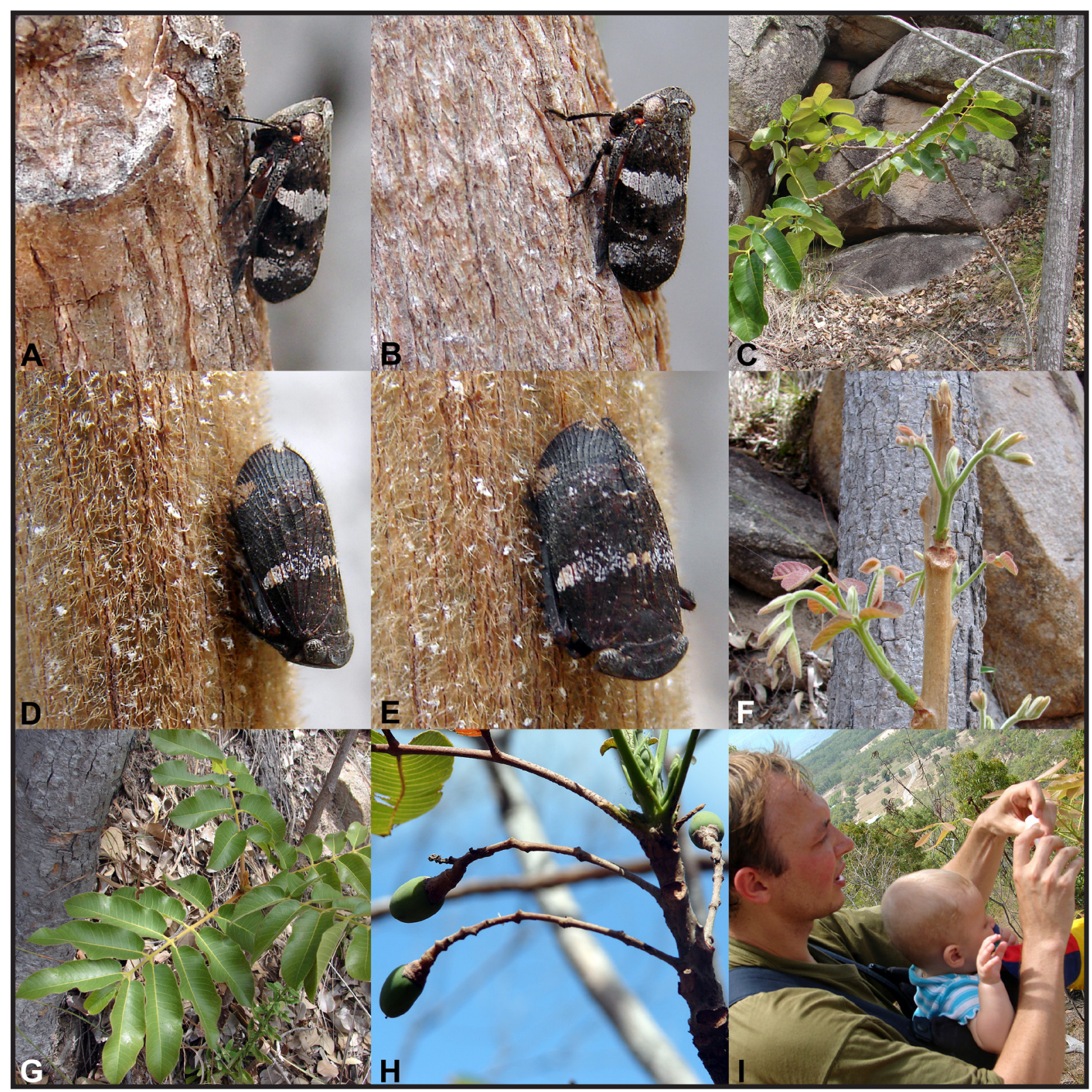

Fig. 24. Olonia marginata Distant, 1906, in nature, Magnetic Island, 8 Nov. 2006, on Canarium australianum F.Muell. saplings. A-B. Male on $2 \mathrm{~m}$ tall sapling. C. Two $\mathrm{m}$ tall sapling of $C$. australianum . D-E. Female on small C. australianum sapling. F. Terminal leaves of small C. australianum sapling. G. Leaves of C. australianum. H. Fruits of C. australianum. I. The author and his 5 month old daughter Emilie observing specimens of $O$. marginata. Photographs by the author except I by L. Despontin. 


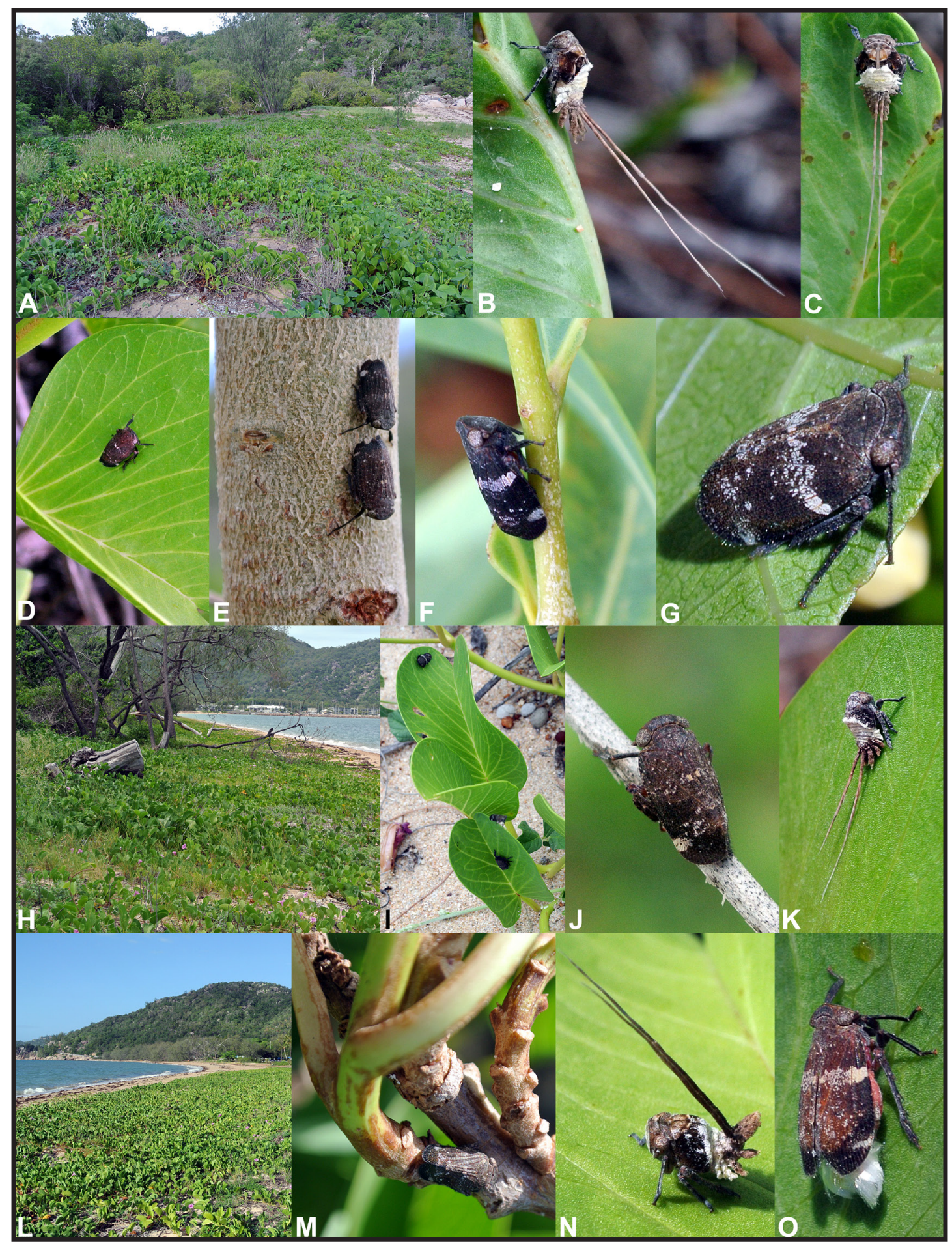

Fig. 25. Olonia marginata Distant, 1906, in nature, Magnetic Island. A-G. Picnic Bay Beach. A. Habitat, 6 Feb. 2016. B-C. Nymph on Ipomoea pes-caprae (L.) R.Br, 6 Feb. 2016. D. Adult on Ipomoea pes-caprae, 6 Feb. 2016. E. Pair on Corymbia tesselaris K.D.Hill \& L.A.S.Johnson regrowth, 31 Jan. 2016. F. Male on Eucalyptus sp. sapling, 10 Jan. 2016. G. Female on Pipturus argentaeus Wedd., 29 Jun. 2014. H-K. Nelly Bay, 11 Feb. 2016. H. Habitat. I. Adults on Ipomoea pes-caprae. J. Male. K. Nymph on Ipomoea pes-caprae. L-O. Geoffrey Bay. L. Habitat, 10 Feb. 2016. M. Male on Ipomoea pes-caprae, 10 Feb. 2016. N. Nymph on Ipomoea pes-caprae, 10 Feb. 2016. O. Female on Ipomoea pes-caprae, 24 Feb. 2016. Photographs by V. Ryland. 
nymphs were observed in Feb. and Apr. (Figs 23B-C, 25B-C, K), and an egg mass in Apr. (Fig. 23D), leading to the conclusion that the species is probably present most of the year. A caterpillar of an unidentified species of Epipyropidae (Lepidoptera) was observed on the back of a female specimen (Fig. 23G).

Olonia marginata is polyphagous and has been collected or observed on Melaleuca quinquenervia (Cav.) S.T.Blake (Myrtaceae), Eucalyptus sp. (Myrtaceae) (Fig. 25F), Canarium australianum F.Muell. (Bursaceae) (Fig. 24), Vitis vinifera L. (Vitaceae), Pipturus argentaeus Wedd. (Urticaceae) (Fig. 25G), Corymbia tesselaris K.D.Hill \& L.A.S.Johnson (Myrtaceae) (Fig. 25E) and in numbers on Ipomoea pescaprae (L.) R.Br. (Convolvulaceae) (Figs 23B-D, F, 25B-D, I-K, M-O), on stems and young branches with a thin skin.

It is interesting to note that the 2016 sampled locations in Magnetic Island and Townsville (Figs 23A, E, H-J, 25A, H, L) were all more or less destroyed by the Tropical Cyclone Yasi in Feb. 2011, which covered these habitats in smashing waves and left them buried under sand and beach debris (pers. com. V. Ryland, Feb. 2016). The species has, however, re-colonised the areas in less than five years, displaying a good degree of adaptation to habitat disturbance.

Olonia maura (Fabricius, 1775)

Figs 3, 27-31

Cicada maura Fabricius, 1775: 686 (described).

Cicada maura-Goeze 1778: 158 (described, catalogued). - Fabricius 1781:326(described, catalogued); 1787: 272 (described); 1794: 40 (described). — Gmelin 1789: 2107 (described, catalogued). — Donovan 1805 (described, illustrated). — Turton 1806: 595 (described).

Flata maura - Fabricius 1803: 51 (described, catalogued, transferred to Flata). — Schaum 1850: 73 (listed).

Cicada matura [sic] - Donovan 1820: 120 (described).

Cercopis maura - Donovan 1820: 121 (described, transferred to Cercopis).

Lystra maura - Germar 1830: 55 (described, catalogued, transferred to Lystra).

Eurymela maura - Signoret 1850: 507 (described (based on a misidentified specimen according to

Distant 1908: 105), transferred to Eurymela). — Walker 1852: 1149 (catalogued). — Kirkaldy 1906: 356 (listed).

Eurybrachys maura - Signoret 1858: xxxii (transferred to Eurybrachys).

Eurymeloides maura - Distant 1908: 105 (transferred to Eurymeloides).

Olonia maura - Evans 1933: 89 (transferred to Olonia). — Metcalf 1956: 64 (catalogued).

\section{Note}

Signoret (1850) based the transfer of this species to Eurymela (Cicadellidae) on a misidentified specimen (Fig. 26). This specimen indeed belongs to the tribe Eurymelini, identified as a member of the genus Platyeurymela Evans, 1933 or Pauroeurymela Evans, 1933 by M.J. Fletcher (pers. com., Apr. 2016) based on the examination of photographs of the specimen in NHMW.

\section{Diagnosis}

The species can be recognized by the following combination of characters:

(1) hind wings without orange marking (Figs 29E, 31E)

(2) pro- and mesofemora and -tibiae largely dark brown (Figs 29A-D, 31A-D)

(3) anal tube of male spatulate, constricted at half length (Fig. 30B) 
(4) centroventral part of gonostyli with strong elongate process tapering distally and with 4-5 apical teeth (Fig. 30A, C)

(5) laterodorsal part of gonostyli with strong furcate process, elongate process strongly curved posterolaterally (Fig. 30A, C-D)

(6) rather small size: $7-8 \mathrm{~mm}$

Females of $O$. maura are nearly impossible to separate from females of the sympatric $O$. picea and should be identified only if collected together with males.

\section{Etymology}

The species epithet maurus (adjective, Latin) means 'Moor', the inhabitants of North Africa, and by extension, 'dark skinned'. It refers to the dark colour of the species.

\section{Material examined}

Lectotype (here designated)

AUSTRALIA - đ'; "Australia”, “63 47”, "BMNH(E) \#668802"; here designated to provide a reference standard for the species; BMNH (Fig. 27).

\section{Paralectotype}

AUSTRALIA • +; “63 47”, “BMNH(E) \#668803”; BMNH (Fig. 28).

\section{Note}

The lectotype and paralectotype are placed together in the Banks collection under two labels: "Cicada maura, Fab. Entom. p. 686.24", "Type". The specimens were collected by Joseph Banks and his team at the mouth of the Endeavour River (coordinates: 15⒉ $7^{\prime} 32^{\prime \prime}$ S, $145^{\circ} 13^{\prime} 28^{\prime \prime}$ E), when Captain James Cook's ship Endeavour was beached and repaired, 17 Jun.-4 Aug. 1770 (Banks 1771).

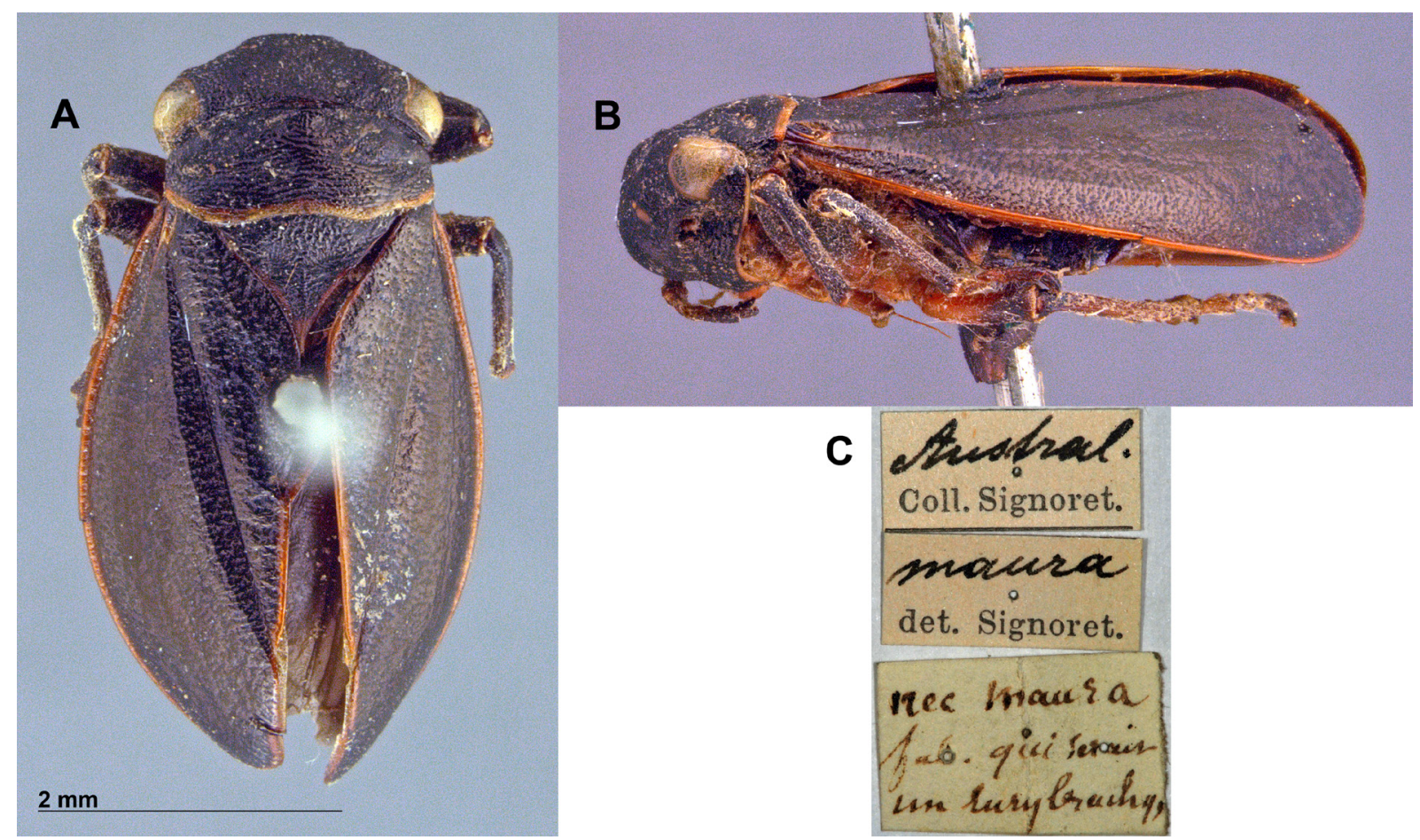

Fig. 26. Eurymelini sp. erroneously identified as Olonia maura (Fabricius, 1775) by Signoret (1850). A. Habitus, dorsal view. B. Habitus, lateral view. C. Labels. Photographs by H. Bruckner (NHMW). 


\section{Additional material}

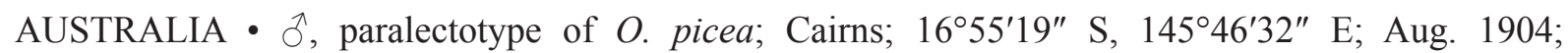

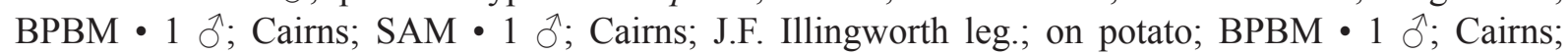

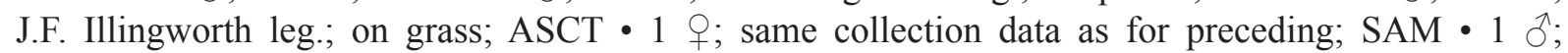
Cairns; J.F. Illingworth leg.; on ti tree; BPBM - 1 ơ; Gordonvale; $17^{\circ} 04^{\prime} 34^{\prime \prime}$ S, $145^{\circ} 47^{\prime} 40^{\prime \prime}$ E; 1 Mar. 1922; E. Jarvis leg.; on Eucalyptus; BMNH - 1 j; same locality as preceding; 28 Jun.

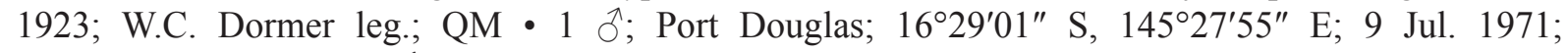

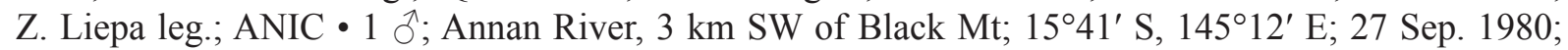

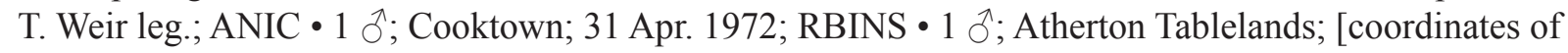

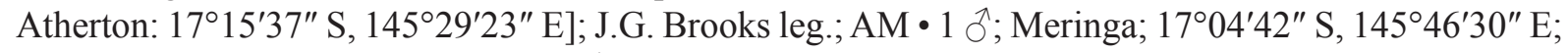
27 Dec. 1946; J. Rosser leg.; QM・1 Ô, 1 q; Meringa; Sep. 1919; F. Muir leg.; BPBM.

\section{Note}

One male labelled "Sol. Is., Guadalcanar I. [sic], 1-1921, J.A. Kusche coll., Collection of W.M. Giffard" from the BPBM has also been examined. This record from the Solomon Islands, very far off the Australian coast, is regarded as highly doubtful and a probable case of mislabeling.

\section{Description}

Measurements and Ratios. LT: $\hat{\jmath}(\mathrm{n}=3): 7.2 \mathrm{~mm}(6.9-7.5) ; \mathrm{BV} / \mathrm{LV}=3.6 ; \mathrm{BF} / \mathrm{LF}=1.82 ; \mathrm{LP}+$ $\mathrm{LM} / \mathrm{BT}=0.62 ; \mathrm{Ltg} / \mathrm{BTg}=2.4 ; \mathrm{LW} / \mathrm{BW}=1.97$.

\section{Male}

HEAD (Figs 27A-D, 29A-D). Vertex slightly concave, with anterior and posterior margins parallel, curved; medium to dark brown with sides slightly darker. Frons uniformly coloured, medium to dark brown. Clypeus elongate, entirely brown. Genae brown to black with yellowish markings along anterior margin. Labium brown to black, reaching metacoxae. Antennae black-brown; scape short, ring-shaped; pedicel subcylindrical, slightly narrowing towards apex.

Thorax (Figs 27A-D, 29A-D). Pronotum uniformly brown, sometimes variegated with yellowish; slightly wrinkled; 2 small impressed points on disc slightly marked; sometimes very obsolete median carina. Lateral fields of prothorax coloured as pronotum. Mesonotum medium to dark brown, somewhat darker than pronotum, sometimes variegated with yellowish; yellowish minute spot at apex of scutellum; median and peridiscal carinae weakly marked; median carina stopping before scutellum; slight impression before scutellum. Red ventrally. Tegulae medium to dark brown.

Tegmina (Figs 27A, C, 29A, C). Medium to dark brown; often pale yellowish marking on vein A1 at midlength of clavus; marked with dark brown or black along costal margin, more broadly so on posterior half, and along posterior margin. Often darker, median, irregular marking at apical $2 / 3$; triangular white marking on costal margin on nodal line, sometimes reduced; sometimes, a number of minute white spots at apicosutural angle. Costal and sutural margins subparallel; costal margin nearly straight; apical margin obliquely rounded.

POSTERIOR WINGS (Fig. 29E). Brown, paler on anal area and progressively darker on apical half; small, subtriangular white marking at apicocostal angle, extending on 2-4 cells. Margin of anal area slightly sinuate; sutural margin with 1 slight cleft, cubital one nearly not marked.

Legs (Figs 27A-D, 29A-D). Pro- and mesocoxae black-brown. Pro- and mesofemora black-brown variegated with brown. Pro- and mesotibiae medium to dark brown, sometimes with 3 paler obsolete rings. Pro- and mesotarsi black-brown with basal half of third tarsomere paler. Metacoxae reddish brown; metafemora reddish with apex brown. Metatibiae brown, with 3 lateral spines paler basally and 9 apical black-brown spines. Metatarsi brown with a ventral row of 6 black spines on first tarsomere. 

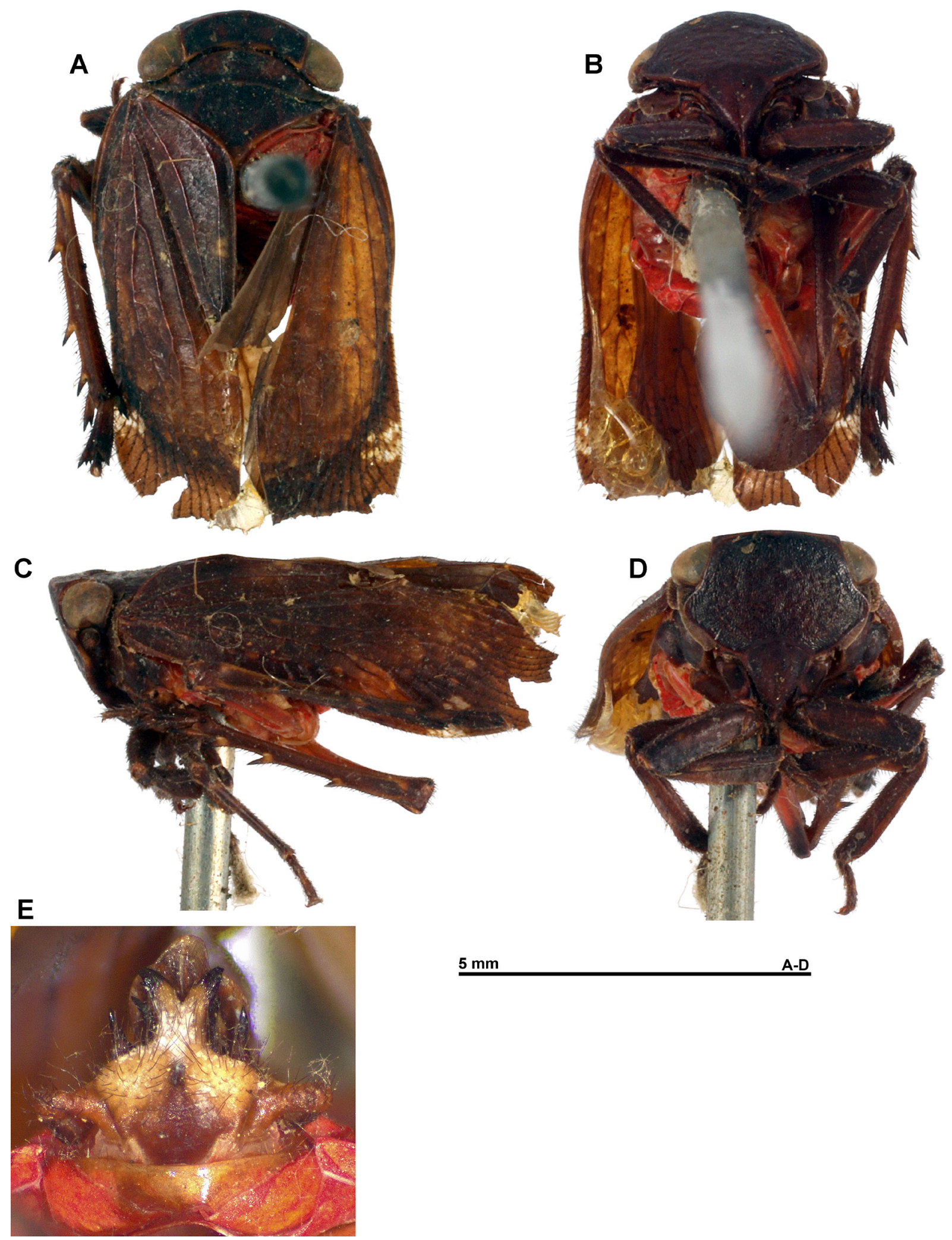

Fig. 27. Olonia maura (Fabricius, 1775), lectotype, ふૈ. A. Habitus, dorsal view. B. Habitus, ventral view. C. Habitus, lateral view. D. Habitus, normal view of frons. E. Genitalia, posteroventral view (not to scale). 


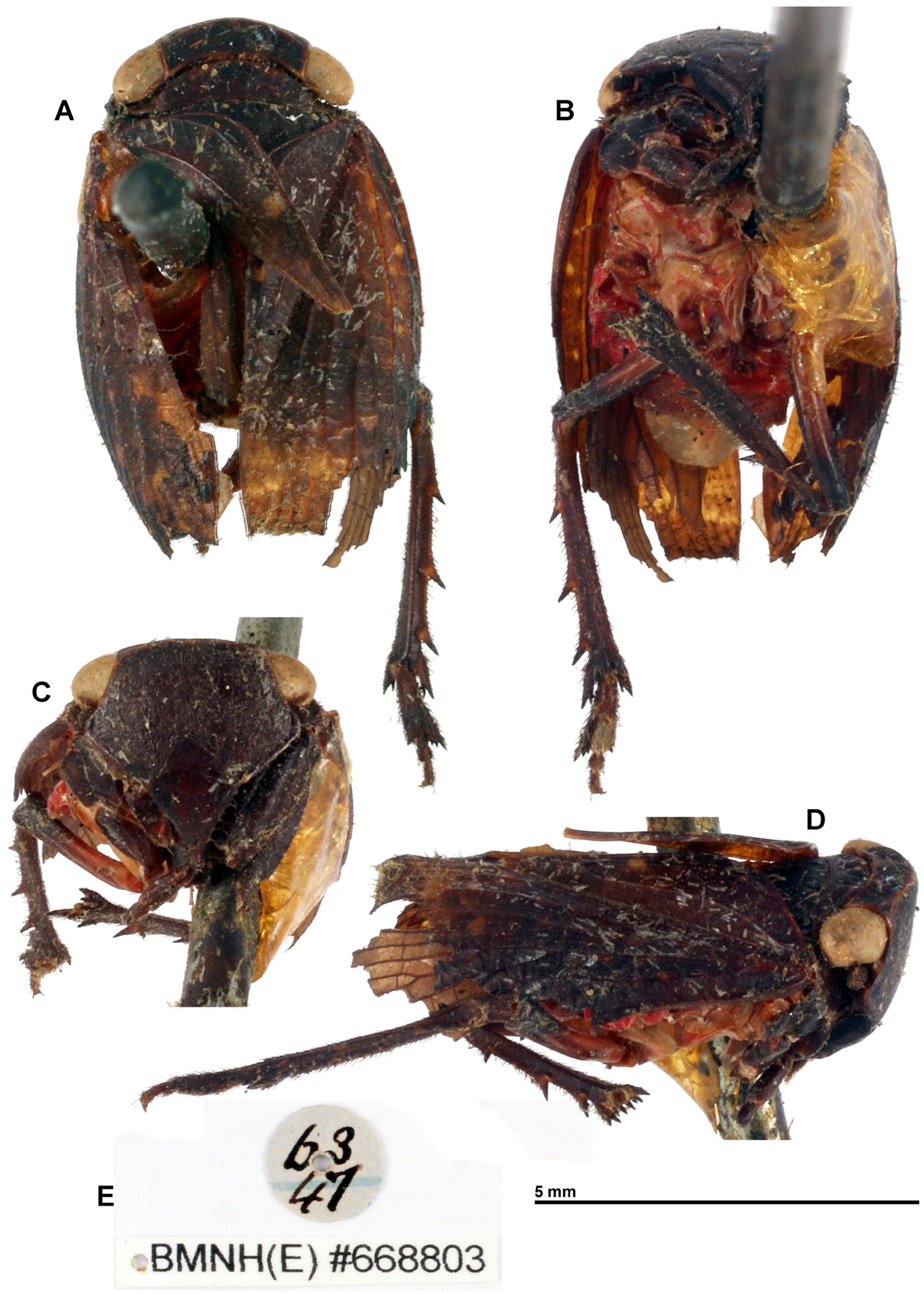

Fig. 28. Olonia maura (Fabricius, 1775), paralectotype, ㅇ. A. Habitus, dorsal view. B. Habitus, ventral view. C. Habitus, normal view of frons. D. Habitus, lateral view. E. Labels. 
AвDOMEN. Bright red with genital segments black-brown.

MALE GENitalia (Fig. 30). Posterior margin of pygofer in lateral view sinuate, strongly roundly projecting at dorsal 1/4, moderately broad ventrally (Fig. 30A, C). Anal tube with lateral margins parallel before epiproct, constricted at level of epiproct, then obovate in apical half, 1.95 times as long as broad,
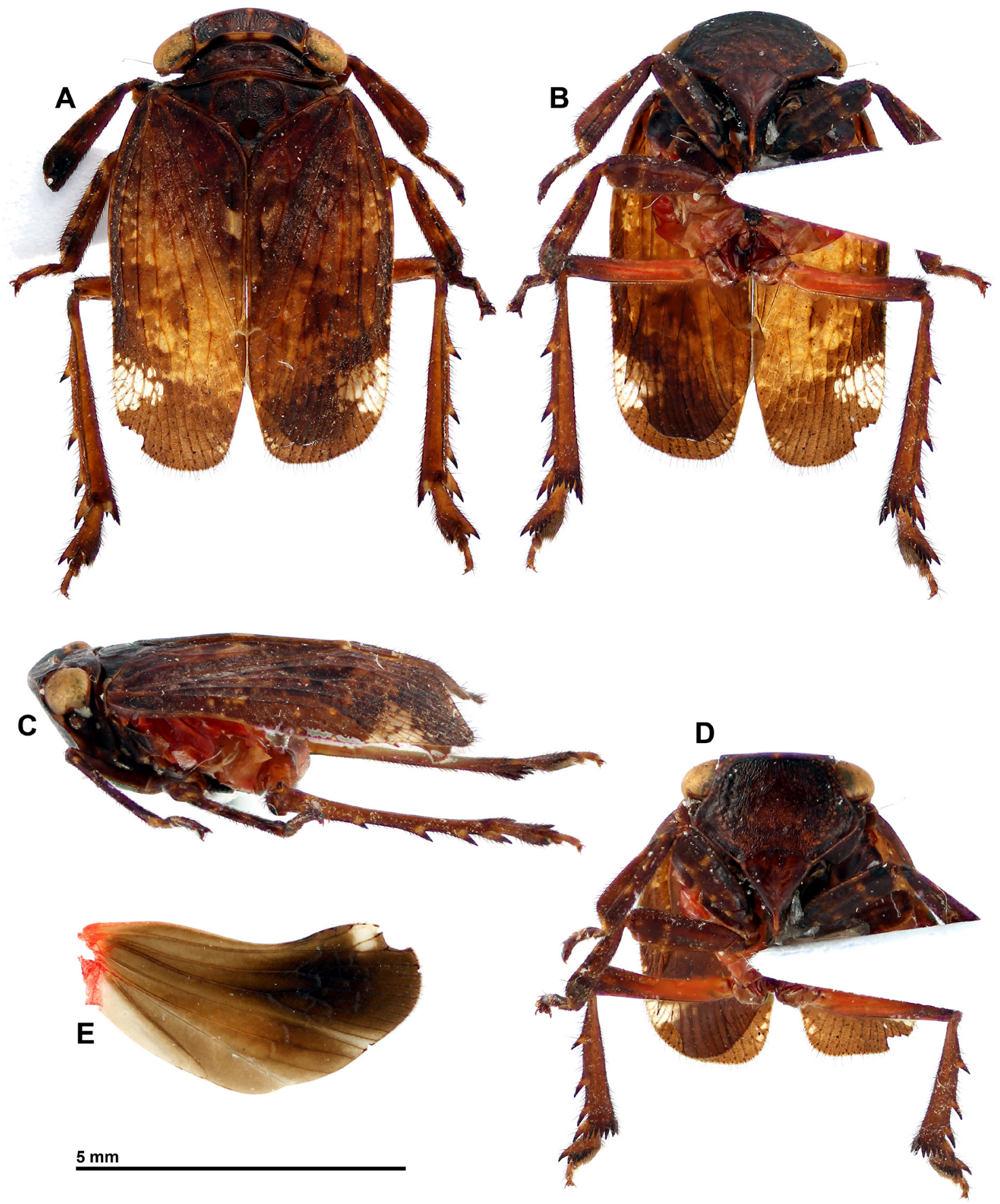

Fig. 29. Olonia maura (Fabricius, 1775), $\widehat{\jmath}$. A. Habitus, dorsal view. B. Habitus, ventral view. C. Habitus, lateral view. D. Habitus, normal view of frons. E. Posterior wing. 


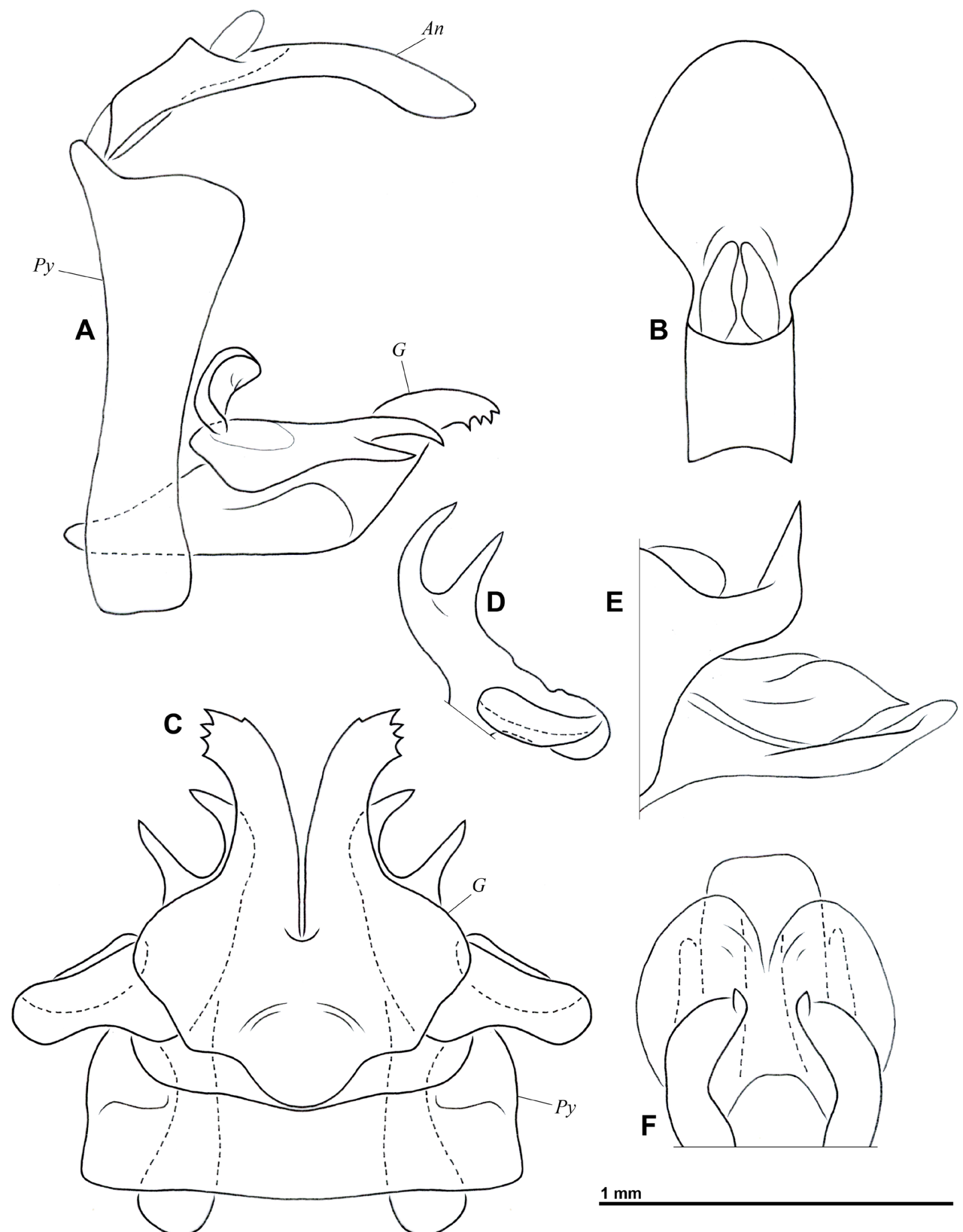

Fig. 30. Olonia maura (Fabricius, 1775), ô, genitalia. A. Pygofer, anal tube and gonostyli, left lateral view. B. Anal tube, dorsal view. C. Pygofer and gonostyli, ventral view. D. Laterodorsal part of left gonostylus, dorsal view. E. Aedeagus, left lateral view. F. Aedeagus, dorsal view. Abbreviations: $A n=$ anal tube; $G=$ gonostyli; $P y=$ pygofer. 

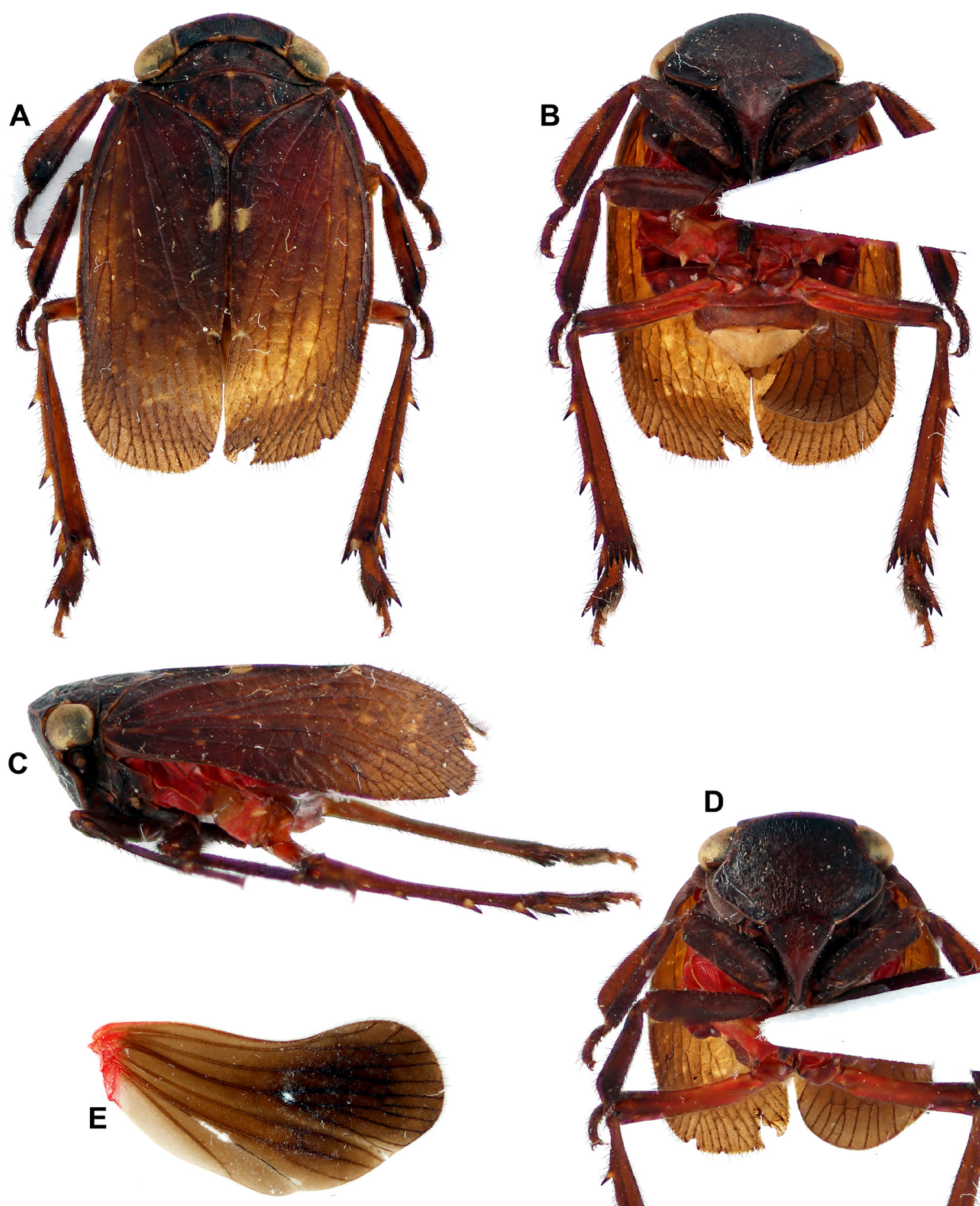

$5 \mathrm{~mm}$

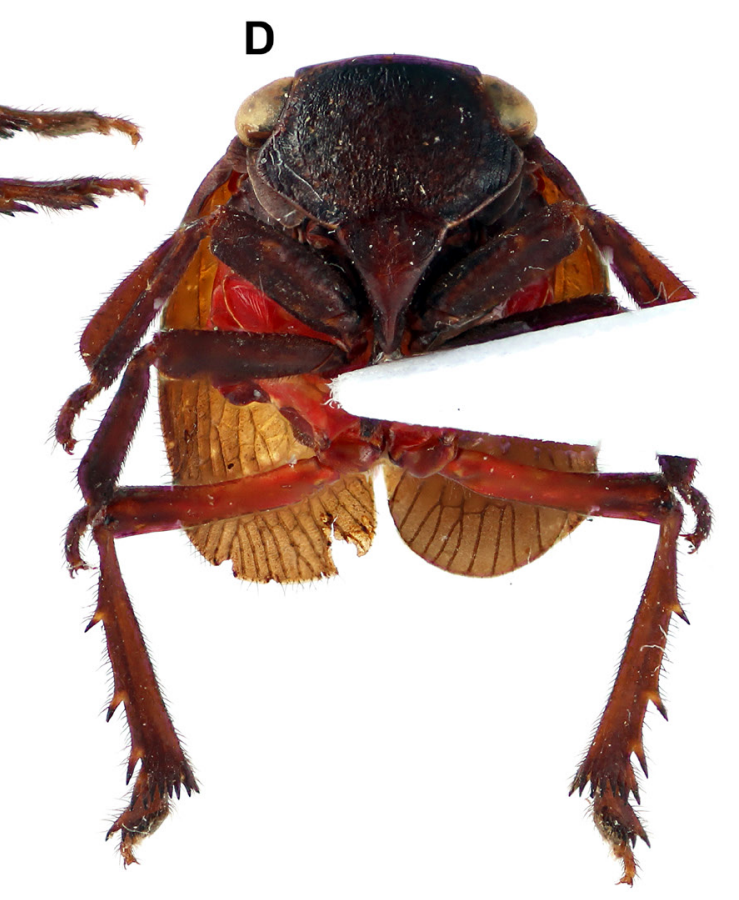

Fig. 31. Olonia maura (Fabricius, 1775), ․ A. Habitus, dorsal view. B. Habitus, ventral view. C. Habitus, lateral view. D. Habitus, normal view of frons. E. Posterior wing. 
slightly curved ventrally in lateral view; apical margin rounded (Fig. 30A-B). Gonostyli fused on basal $2 / 5$ of length of centroventral part and projecting posterodorsally (Fig. 30A, C). Centroventral part broad and dorsoventrally flattened on basal 2/5, then with 2 strong divergent processes projecting posterodorsally, with apex curved ventrally and bearing 4-5 strong teeth (Fig. 30A, C). Laterodorsal part of gonostyli elongate and directed posterolaterally, dorsoventrally flattened, shorter than centroventral part and strongly bifid, apically with the two processes subparallel; lateral process elongate, projecting anterolaterally and about as long as spoon-shaped process (Fig. 30A, C-D). Dorsal portion of phallobase with hooked process on each side, progressively narrowing from base to apex, directed posterocentrally, slightly converging posteriorly, curved in dorsal view and with apex pointing dorsally (Fig. 30E-F). Ventral portion of phallobase unilobed in dorsal view, with median lobe surpassing phallus (Fig. 30EF). Phallus dorsoventrally flattened, rather broad, with apical margin deeply emarginate in middle (Fig. 30E-F).

\section{Female}

Similar to male, but without white spot on costal margin of tegmina at nodal line and with white spot at apicosutural angle of posterior wing strongly reduced, visible as a small, slightly paler marking (Fig. 31).

\section{Distribution and biology}

This species is currently recorded from an area around Cairns in North Queensland (Fig. 3), in the Cape York Peninsula Tropical Savanna and Queensland Tropical Rainforests bioregions. Specimens were collected in March, April, June, July and August. One specimen was collected on Solanum tubiferum L. (Solanaceae) and one on Eucalyptus sp.

Olonia monteithi sp. nov. urn:1sid:zoobank.org:act:B4773609-83FD-4B11-9982-D4F96C291299

Figs 3, 32-34

\section{Diagnosis}

This species can be recognized by the following combination of characters:

(1) hind wings without orange marking (Figs 32E, 34E) and with apical margin bordered with white in females (Fig. 34E)

(2) pro- and mesofemora and -tibiae largely black-brown (Figs 32A-D, 34A-D)

(3) anal tube of male obovate after epiproct and with posterior margin truncate (Fig. 33B)

(4) centroventral part of gonostyli with strong pointed processes curved laterally (Fig. 33A, C)

(5) laterodorsal part of gonostyli bifid, with dorsal process shorter than ventral one and both directed posteriorly (Fig. 33A, C-D)

(6) medium size: $8.3-9.7 \mathrm{~mm}$

\section{Etymology}

This species is dedicated to Dr Geoff Monteith, who collected the type specimens.

\section{Type material}

Holotype

AUSTRALIA - ${ }^{\wedge}$; NE Queensland, Bakers Blue Mt, $17 \mathrm{~km} \mathrm{~W}$ of Mt Molloy; [16 $\left.42^{\prime} \mathrm{S}, 145^{\circ} 09^{\prime} \mathrm{E}\right]$; "N.E. QLD, Bakers Blue Mt, 17 km W Mt Molloy, 800m, open For. 12.ix.1981, G. Monteith \& D. Cook", "QM-T24410"; QM.

\section{Paratype}

AUSTRALIA • 1 क; same collection data as for holotype; QM. 


\section{Description}

Measurements and Ratios. LT: ô $(\mathrm{n}=1): 8.3 \mathrm{~mm}$; $q(\mathrm{n}=1): 9.7 \mathrm{~mm} ; \mathrm{BV} / \mathrm{LV}=4.26 ; \mathrm{BF} / \mathrm{LF}=1.67$; $\mathrm{LP}+\mathrm{LM} / \mathrm{BT}=0.64 ; \mathrm{Ltg} / \mathrm{BTg}=2.47 ; \mathrm{LW} / \mathrm{BW}=1.84$.

\section{Male}

HEAD (Fig. 32A-D). Vertex concave, with anterior and posterior margins parallel, curved; black-brown slightly variegated with brown. Frons black-brown slightly wrinkled and with paler markings along dorsal margin. Clypeus elongate, black-brown, tinged with reddish in middle and with small reddish point at basolateral angles. Genae brown-black with yellowish markings around eyes and along anterior margin. Labium black-brown, reaching metacoxae. Antennae black-brown; scape short, ring-shaped; pedicel subcylindrical, slightly narrowing towards apex.

Thorax (Fig. 32A-C). Pronotum black-brown slightly variegated with yellowish along anterior margin and with small yellowish spot at lateral angles; slightly transversely wrinkled posteriorly; obsolete median carina and 2 small impressed points on disc. Lateral fields of prothorax black-brown. Mesonotum blackbrown, slightly wrinkled, with apex of scutellum slightly reddish; median and peridiscal carinae weakly marked; median carina stopping before scutellum; slight impression before scutellum. Red ventrally. Tegulae black-brown.

TEgmina (Fig. 32A, C). Black-brown with median area paler; small reddish spots on basal half and clavus; large white transverse marking along costal margin at half length, with additional smaller white spots in a row; large triangular white marking on costal margin on nodal line, nearly extending to white spots at apicosutural angle. Maximum breadth at basal $1 \frac{1}{3}$; costal margin sinuate; apical margin obliquely rounded.

Posterior wings (Fig. 32E). Brown with apical half turning to black and anal area paler; transverse, broad, subtriangular white marking at apicocostal angle, extending on 7-8 cells. Margin of anal area slightly sinuate; sutural margin with 2 clefts, cubital one slightly marked.

Legs (Fig. 32A-D). Pro- and mesocoxae black-brown. Pro- and mesofemora black-brown with 2 obsolete yellowish rings. Pro- and mesotibiae black-brown with 3 obsolete yellowish rings, larger one near apex. Pro- and mesotarsi dark brown with basal half of third tarsomere paler. Metacoxae reddish brown; metafemora red with apex black-brown. Metatibiae brown, with 3 lateral spines slightly yellowish basally and 8 apical, black-brown spines. Metatarsi dark brown, with a ventral row of 6 black spines on first tarsomere.

AвDOMEN. Bright red with genital segments black-brown.

MALE GENITALIA (Fig. 33). Posterior margin of pygofer in lateral view sinuate, strongly roundly projecting at dorsal $1 / 3$, moderately broad ventrally (Fig. 33A, C). Anal tube with lateral margins subparallel before epiproct, constricted at level of epiproct, then obovate in apical half, 2.33 times as long as broad, slightly curved ventrally in lateral view; apical margin roundly truncate (Fig. 33A-B). Gonostyli fused on basal $2 / 5$ of length of centroventral part and projecting posterodorsally (Fig. 33A, C). Centroventral part broad and dorsoventrally flattened on basal $2 / 5$, then with 2 strong divergent processes curved laterally and pointed apically (Fig. 33A, C). Laterodorsal part of gonostyli elongate and directed posterodorsally, laterally flattened, not surpassing centroventral part and strongly bifid apically, with the two pointed processes forming an open $\mathrm{C}$ and projecting posteriorly, dorsal process shorter than ventral one; lateral process elongate, projecting posterolaterally and slightly longer than spoon-shaped process (Fig. 33A, C-D). Dorsal portion of phallobase with hooked process on each side, progressively narrowing from base to apex, directed dorsally, slightly converging apically (Fig. 33E-F). Ventral portion of phallobase unilobed in dorsal view, broadly rounded apically and with median lobe surpassing phallus (Fig. 33EF). Phallus dorsoventrally flattened, rather broad, with apical margin deeply emarginate in middle (Fig. 33E-F). 

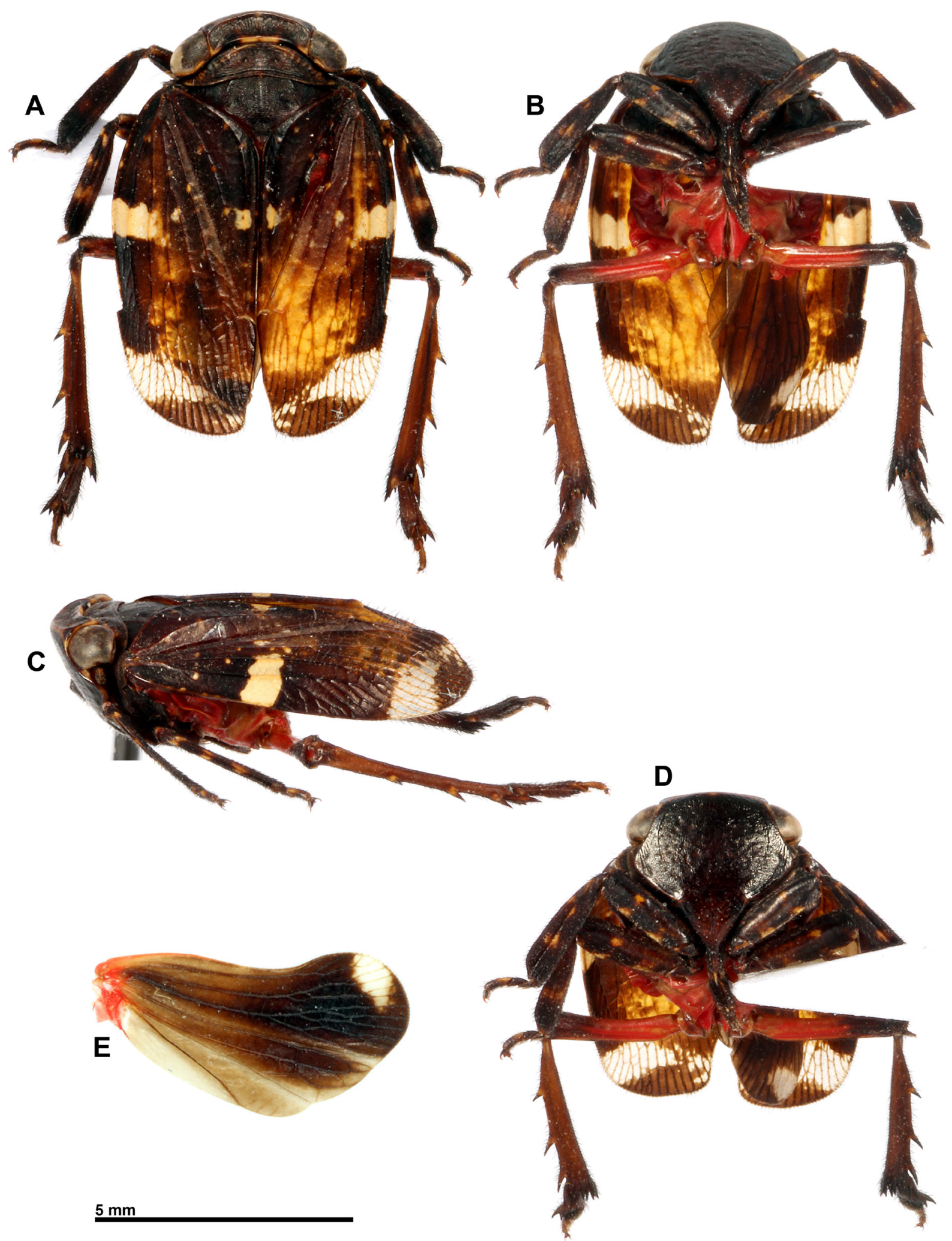

Fig. 32. Olonia monteithi sp. nov., holotype, Ô. A. Habitus, dorsal view. B. Habitus, ventral view. C. Habitus, lateral view. D. Habitus, normal view of frons. E. Posterior wing. 


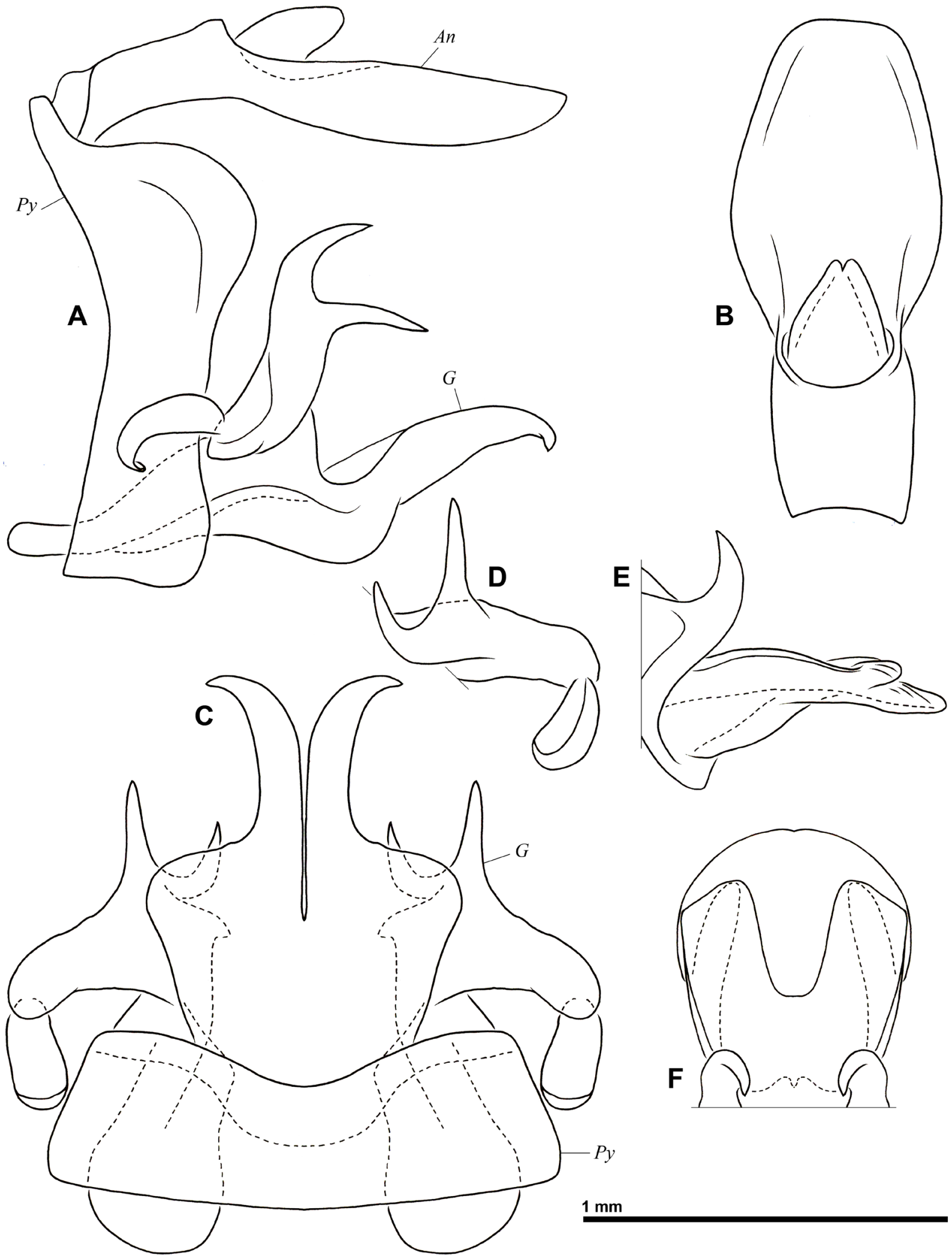

Fig. 33. Olonia monteithi sp. nov., holotype, $\hat{o}$, genitalia. A. Pygofer, anal tube and gonostyli, left lateral view. B. Anal tube, dorsal view. C. Pygofer and gonostyli, ventral view. D. Laterodorsal part of left gonostylus, dorsal view. E. Aedeagus, left lateral view. F. Aedeagus, dorsal view. Abbreviations: $A n=$ anal tube; $G=$ gonostyli; $P y=$ pygofer. 

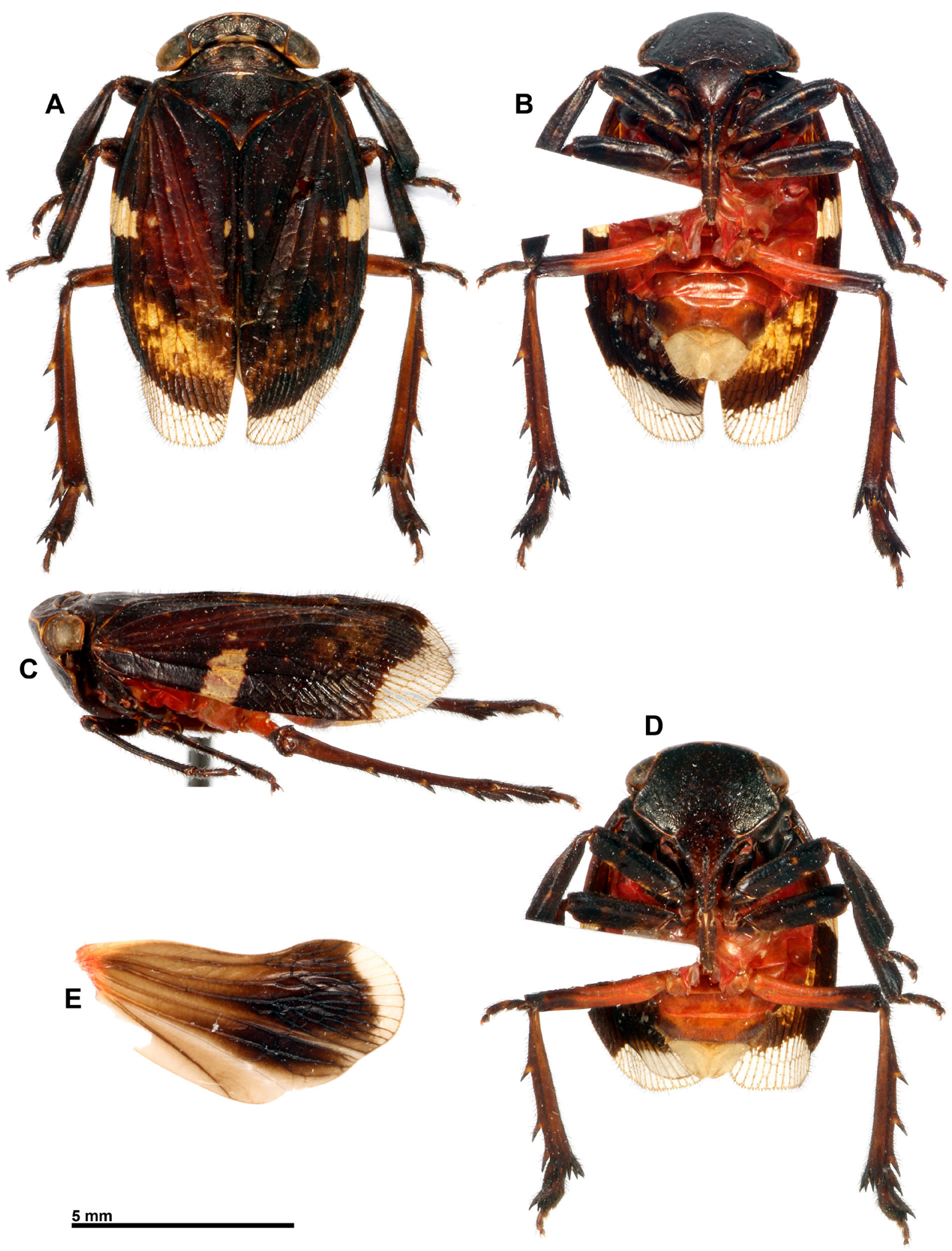

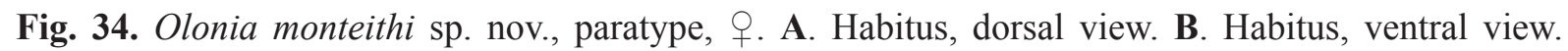
C. Habitus, lateral view. D. Habitus, normal view of frons. E. Posterior wing. 


\section{Female}

Similar to male, but with markings on anterior and median legs less visible; tegmina with apical margin largely bordered with white; posterior wings with apical margin largely bordered with white, white area extending on 11 cells (Fig. 34).

\section{Distribution and biology}

This species is currently recorded from Blue Bakers Mountain, an isolated mountain area in North Queensland (Fig. 3), in the Einasleigh Upland Savanna bioregion. The specimens were collected in November in open forest at $800 \mathrm{~m}$ a.s.l. In an unpublished report available on the Internet, Ingram (1998) mentions that the location is a refuge with many endemic species of invertebrates (molluscs and isopods).

Olonia nobilis (Stål, 1863) comb. nov.

Figs 3, 35-39

Lyncilia nobilis Stål, 1863: 248 (described).

Lyncilia nobilis - Kirkaldy 1906: 448 (mentioned as unknown to the author in a work on Australian Auchenorrhyncha). - Metcalf 1956: 68 (catalogued).

Platybrachys nobilis - Fennah 1964: 160 (transferred to Platybrachys Stål, 1959; nomen implicitum).

Note

Fennah (1964) synonymized Lyncilia Stål, 1863 with Platybrachys Stål, 1859 but failed to formally propose the new combination Platybrachys nobilis (Stål, 1863) for the single species contained in that genus. The latter combination is here treated as a nomen implicitum. Examination of the holotype and recent additional material of Lyncilia nobilis revealed that the species actually belongs to the genus Olonia.

\section{Diagnosis}

This species can be recognized by the following combination of characters:

(1) hind wings with large conspicuous orange marking (Figs 36E, 38E) and with narrow apical white border in females (Fig. 38E)

(2) pro- and mesofemora and -tibiae largely black-brown (Figs 36A-D, 38A-D)

(3) anal tube of male acuminate apically and narrowing basally to level of epiproct (Fig. 37B)

(4) centroventral part of gonostyli with long and narrow process curved ventrointernally (Fig. 37A, C)

(5) laterodorsal part of gonostyli with long and narrow process curved ventrally (Fig. 37A, C-D)

(6) rather large size: $9-11 \mathrm{~mm}$

\section{Material examined}

\section{Holotype}

AUSTRALIA • + ; Queensland, Lizard Island; [1440'08" S, 145²7'34" E]; "Lizard Inseln", "Type", "Lyncilia nobilis Stål,, , Edm. Schmidt determ. 1907", "Mus. Zool. Polonicum Warszawa 12/45"; ZMPA (Fig. 35).

\section{Other material}

AUSTRALIA • 1 §̧; NE Queensland, Lizard Island; 5 Jul. 1987; J. Grimshaw leg.; QDPI • 2 q $\circ$; collection data as for preceding; on track to airstrip; $8 \mathrm{Jul}$. 1987; QDPI 11 क; collection data as for preceding; 3 Jul. 1987; hand collected near research station; QDPI 1 1 ; same collection data as for preceding; RBINS • 1 §, 1 क ; Lizard Island; 15 Nov. 1974; M.S. and B.J. Moulds leg.; AMS. 


\section{Material examined from photographs}

AUSTRALIA • 2 우; Lizard Island, Casuarina Beach; 1 Mar. 2016; A. Hoggett leg.; on Ipomoea pescaprae.

\section{Description}

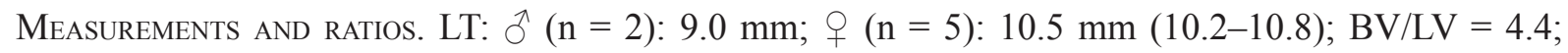
$\mathrm{BF} / \mathrm{LF}=1.76 ; \mathrm{LP}+\mathrm{LM} / \mathrm{BT}=0.68 ; \mathrm{Ltg} / \mathrm{BTg}=2.2-2.4 ; \mathrm{LW} / \mathrm{BW}=1.72$.

\section{Male}

HEAD (Fig. 36A-D). Vertex concave, with anterior and posterior margins parallel, curved; brown variegated with yellowish. Frons reddish black-brown, slightly rugulose. Clypeus elongate, dark reddish brown. Genae black-brown with yellowish markings around eyes and along anterior margin. Labium black-brown, reaching metacoxae. Antennae dark brown; scape short, ring-shaped; pedicel subcylindrical, slightly narrowing towards apex.

Thorax (Fig. 36A-D). Pronotum brown variegated with yellowish and blackish; slightly transversely wrinkled posteriorly; obsolete median carina and 2 small impressed points on disc. Lateral fields of prothorax dark brown. Mesonotum dark brown variegated with reddish and blackish, with median yellowish spot along anterior margin and at apex of scutellum; slightly transversely wrinkled; median and peridiscal carinae weakly marked; median carina stopping before scutellum; slight impression before scutellum. Red ventrally. Tegulae brown.

Tegmina (Fig. 36A, C). Brown with costal margin along posterior half and apical margin after nodal line, bordered with black; small reddish to yellowish spots; conspicuous transverse, white marking along costal margin at half length; small white marking on vein A1 at half length of clavus; triangular white marking on costal margin on nodal line; white spot at apicosutural angle. Maximum breadth at basal third; costal margin sinuate; apical margin obliquely rounded.

Posterior wings (Fig. 36E). Bright orange with apical $1 / 3$ black; basal $1 / 4$ between anal fold and vein MP, anal area and border along sutural margin brown; transverse, broad, white marking at apicocostal angle, extending on 2 cells. Margin of anal area straight; sutural margin with 2 clefts, cubital one slightly marked.

Legs (Fig. 36A-D). Pro- and mesocoxae black-brown. Pro- and mesofemora black-brown. Pro- and mesotibiae black-brown with 3 obsolete ring-shaped reddish to yellowish markings, larger one near apex, more developed on mesotibiae. Pro- and mesotarsi dark brown, with basal half of third tarsomere paler. Metacoxae reddish brown; metafemora reddish with apex dark brown. Metatibiae brown, with 3 lateral spines yellowish basally and 8 apical, black-brown spines. Metatarsi dark brown, with a ventral row of 6 black spines on first tarsomere.

AвDOMEN. Bright red with genital segments black-brown.

MALE GENitALIA (Fig. 37). Posterior margin of pygofer in lateral view strongly sinuate, strongly roundly projecting at dorsal 1/2, narrow ventrally (Fig. 37A, C). Anal tube subovate, 2.1 times as long as broad, laterally emarginate at level of epiproct, curved ventrally in lateral view; lateral margins slightly curved ventrally on apical $2 / 3$; narrowing and acuminate apically (Fig. 37A-B). Gonostyli fused basally and projecting posteroventrally (Fig. 37A, C). Centroventral part elongate and narrow, diverging at base, then curved centroventrally, crossing near apex (Fig. 37A, C). Laterodorsal part of gonostyli elongate and narrow, progressively slightly curved posteroventrally, ventrally surpassing level of centroventral part; lateral process elongate, projecting lateroventrally and slightly concave dorsally; slightly longer than spoon-shaped process (Fig. 37A, C-D). Dorsal portion of phallobase with short and strong hooked process on each side, abruptly curved dorsally (Fig. 37E-F). Ventral portion of phallobase forming 

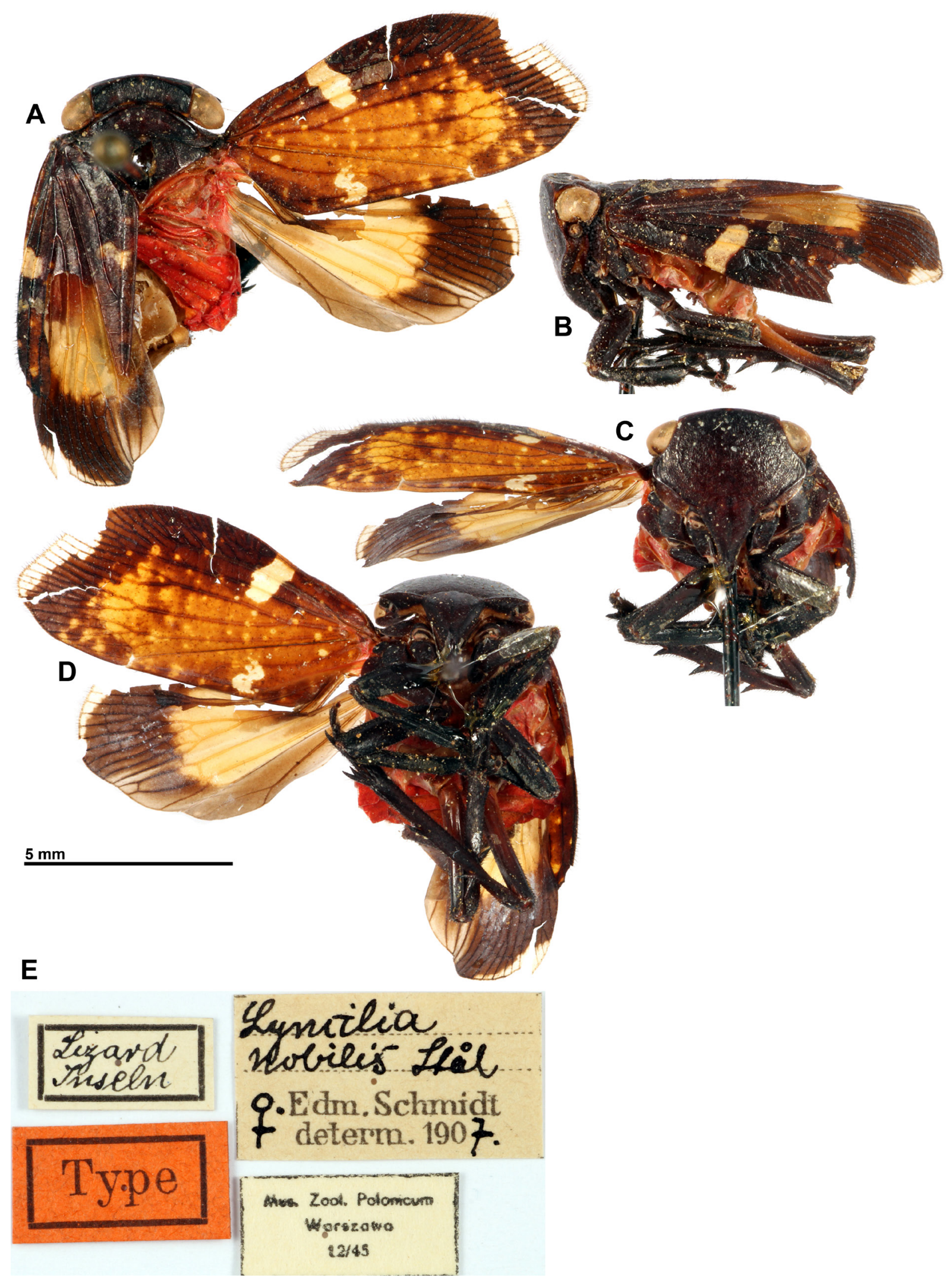

Fig. 35. Olonia nobilis (Stål, 1863) comb. nov., holotype, q. A. Habitus, dorsal view. B. Habitus, lateral view. C. Habitus, normal view of frons. D. Habitus, ventral view. E. Labels. 

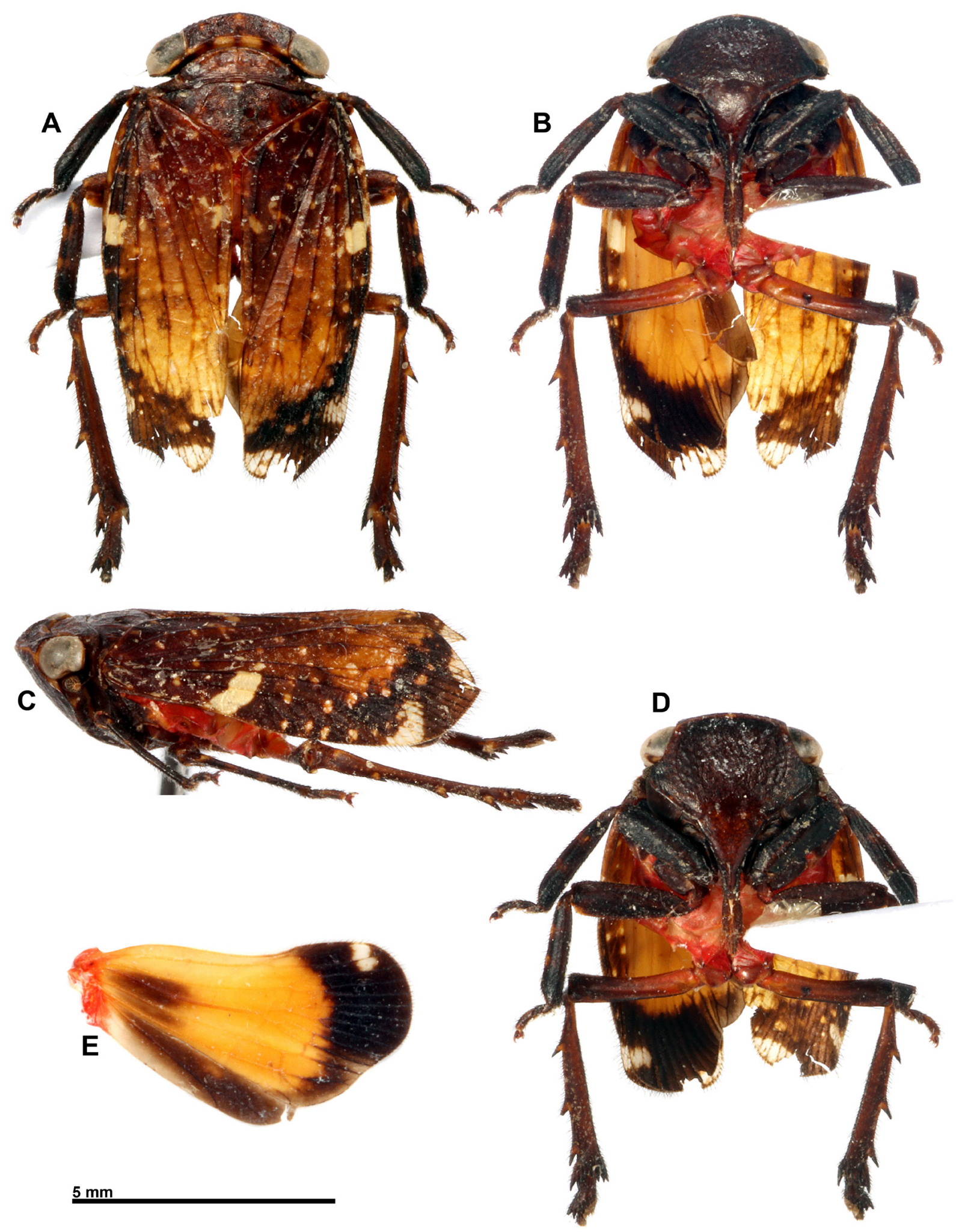

Fig. 36. Olonia nobilis (Stål, 1863) comb. nov., ô. A. Habitus, dorsal view. B. Habitus, ventral view. C. Habitus, lateral view. D. Habitus, normal view of frons. E. Posterior wing. 
elongate process along each side of phallus, not merging apically (Fig. 37E-F). Phallus dorsoventrally flattened, obovate (Fig. 37E-F).

\section{Female}

Similar to male, but tegmina without white spot along costal margin on nodal line and at apicosutural angle, replaced by narrow white border along apical margin; posterior wings brown with apical $1 / 4$ black,

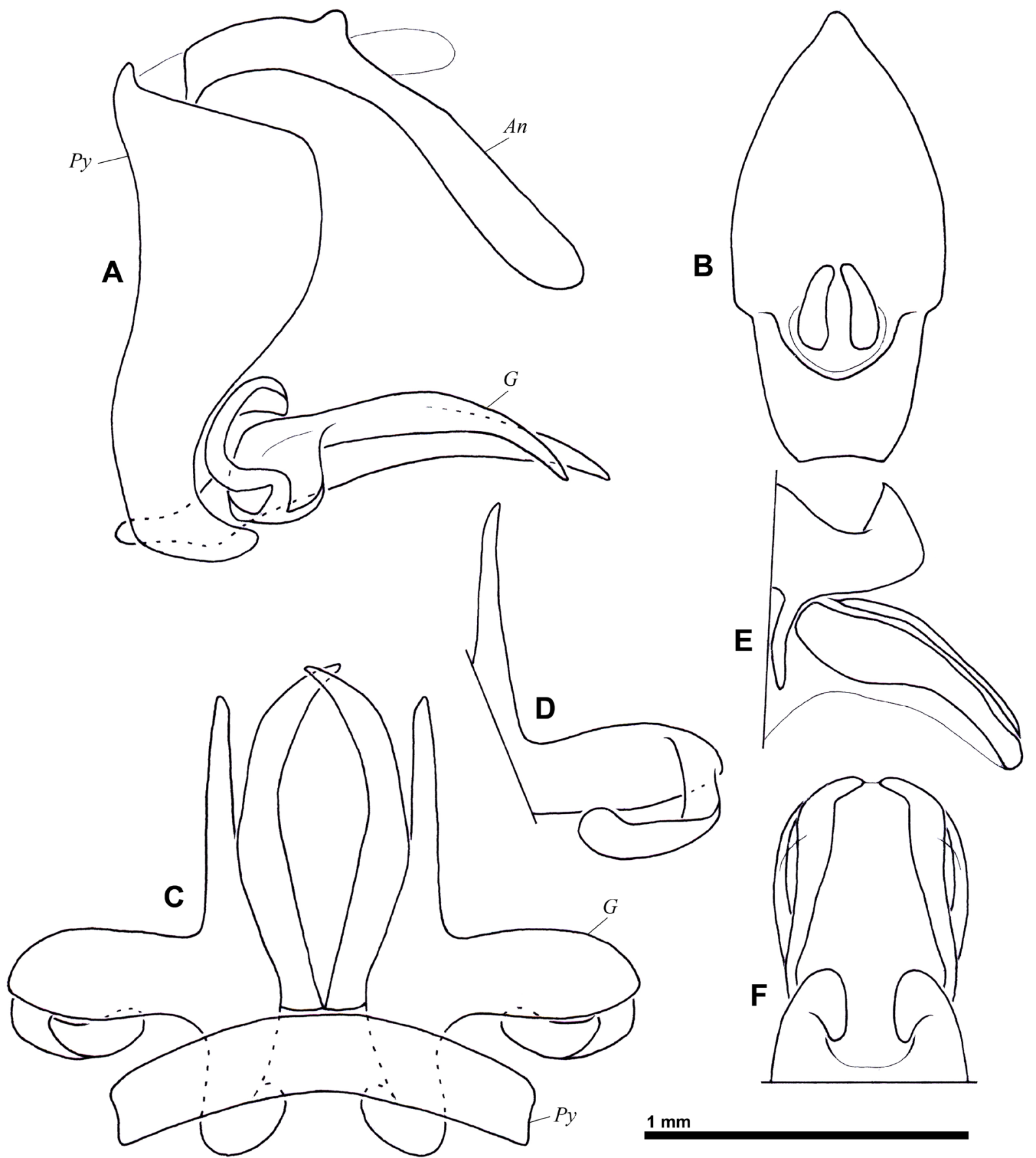

Fig. 37. Olonia nobilis (Stål, 1863) comb. nov., ô, genitalia. A. Pygofer, anal tube and gonostyli, left lateral view. B. Anal tube, dorsal view. C. Pygofer and gonostyli, ventral view. D. Laterodorsal part of left gonostylus, dorsal view. E. Aedeagus, left lateral view. F. Aedeagus, dorsal view. Abbreviations: $A n=$ anal tube; $G=$ gonostyli; $P y=$ pygofer. 

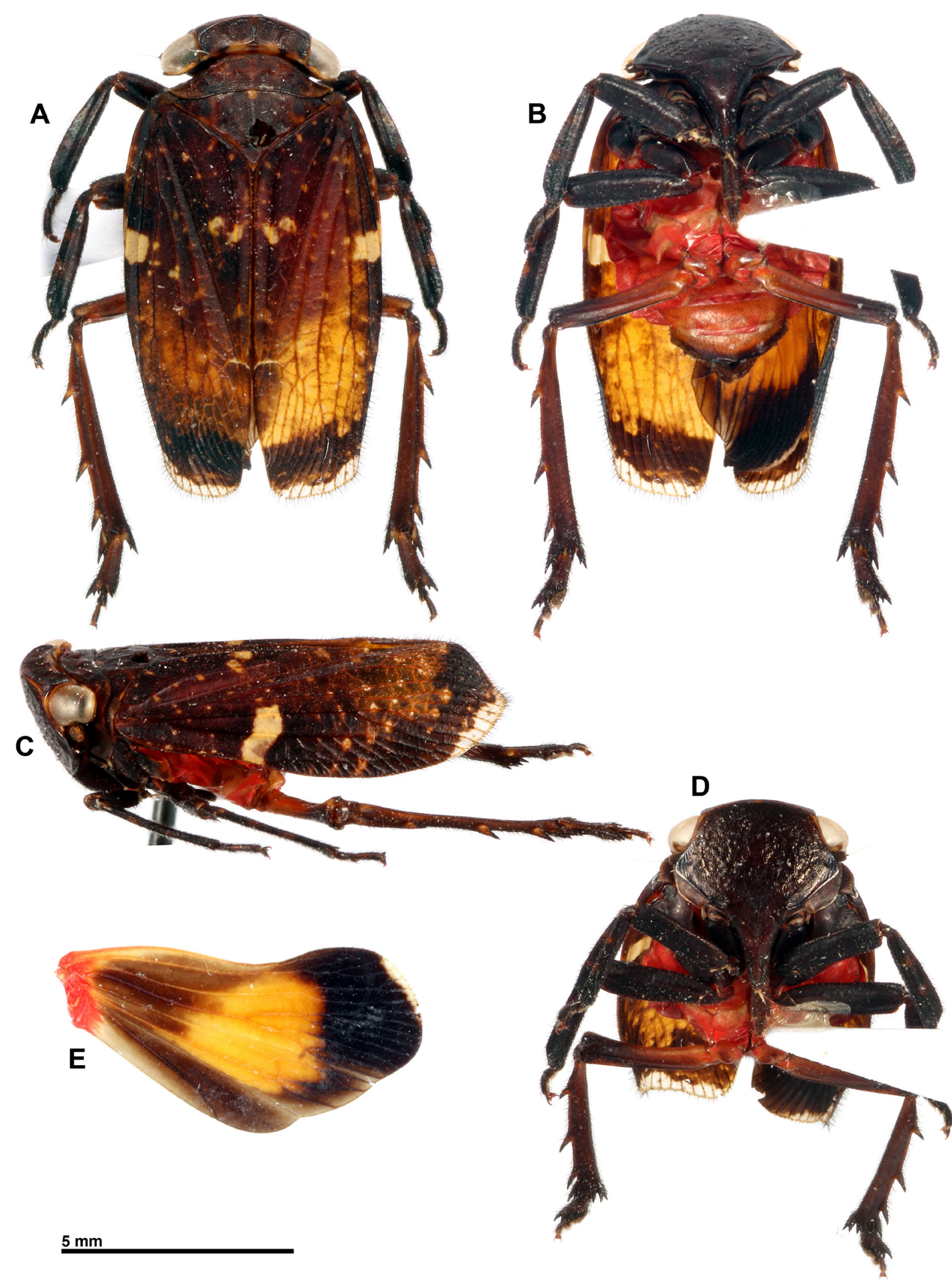

Fig. 38. Olonia nobilis (Stål, 1863) comb. nov., ․ A. Habitus, dorsal view. B. Habitus, ventral view. C. Habitus, lateral view. D. Habitus, normal view of frons. E. Posterior wing. 
large central bright orange marking extending from anal fold to vein $\mathrm{ScP}+\mathrm{R}$, and apical margin narrowly bordered with white along 5-6 cells (Fig. 38).

\section{Distribution and biology}

This species has only been recorded from Lizard Island, a small $10 \mathrm{~km}^{2}$ island where it seems to be restricted, off the eastern coast of Cape York Peninsula (Fig. 3) in the Cape York Peninsula Tropical Savanna bioregion. The specimens were found in March, July and November, at low altitude according to the available data (the island culminates at $359 \mathrm{~m}$ a.s.1.). Several specimens were observed on stems of Ipomoea pes-caprae but not on those of I. macrantha Roem. \& Schult. (A. Hoggett pers. com.) (Fig. 39).

\section{Olonia picea Kirkaldy, 1906}

Figs 3, 40-43

Olonia picea Kirkaldy, 1906: 445 (described; compared with O. rubicunda, O. transversa and O. apicalis).

Olonia picea - Kershaw \& Muir 1922: 208 (note on male genitalia). — Muir 1923: 231, pl. 5, fig. 12 (male genitalia described and illustrated). - Jacobi 1928 (synonymized with $O$. transversa (erroneous)). - Metcalf 1956: 66 (catalogued, as O. transversa (erroneous)). — Constant 2005b: 66 (removed from synonymy with $O$. transversa).

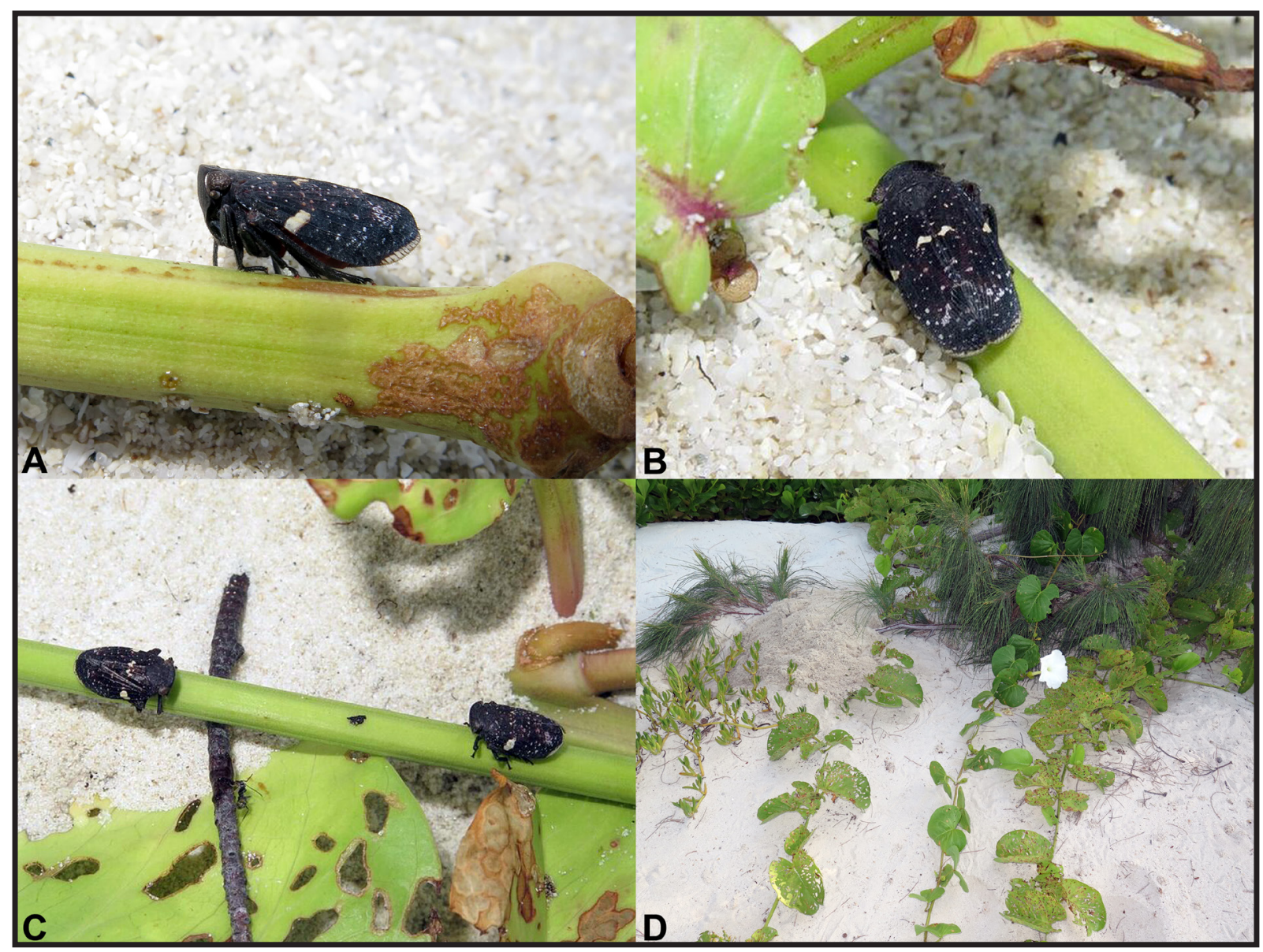

Fig. 39. Olonia nobilis (Stål, 1863) comb. nov. in nature, Lizard Island, Casuarina Beach, 1 Mar. 2016. A-B. Female on Ipomoea pes-caprae. C. Two females on Ipomoea pes-caprae. D. Habitat. Photographs by A. Hoggett. 


\section{Diagnosis}

This species can be recognized by the following combination of characters:

(1) hind wings without orange marking (Figs 41E, 43E)

(2) pro- and mesofemora and tibiae largely black-brown (Figs 41A-D, 43A-D)

(3) anal tube of male obovate, narrowing at basal $1 / 3$ (Fig. 42B)

(4) centroventral part of gonostyli with strong, elongate process curved laterally and pointed apically (Fig. 42A, C)

(5) laterodorsal part of gonostyli strongly bifid, with dorsal and ventral process forming a $\mathrm{C}$ together (Fig. 42A, C-D)

(6) rather small size: $6.5-7.5 \mathrm{~mm}$

Females of $O$. picea are nearly impossible to separate from females of the sympatric O. maura and should be identified only if collected together with males.

\section{Etymology}

The species epithet piceus (adjective, Latin) means 'piceous', 'brown'. It refers to the general colour of the species.

\section{Material examined}

Lectotype (here designated)

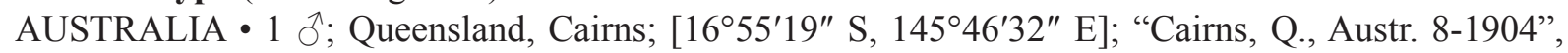
"Allotype", "Olonia picea Kirk. $\widehat{O}^{\top} 308$ "; here designated to provide a reference standard for the species; BPBM (Fig. 40).

\section{Paralectotypes}

AUSTRALIA • 1 क; "Cairns, Q., Austr. 7, 1904”, "Holotype”, “Olonia picea Kirk. + 308”; BPBM •

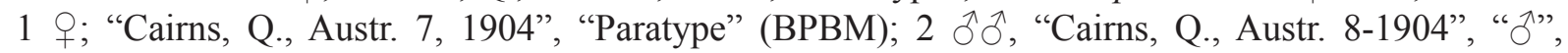
"Paratype"; BPBM.

\section{Note}

One of the two male paralectotypes is actually a male of $O$. maura (Fabricius, 1775).

\section{Additional material}

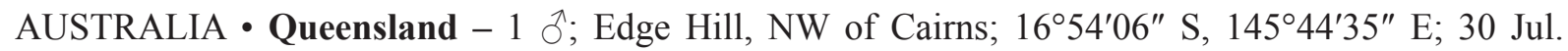
1969; James E. Tobler leg.; CAS • 1 ; ; same collection data as for preceding; 20 Aug. 1969; RBINS

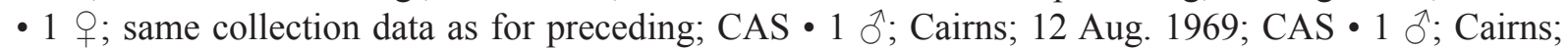
26 Feb.-1 Mar. 1985; W. Middlekauff leg.; CAS • 1 đ ; Cairns, Pine Creek; 18 Jan. 1962; E.B. Britton and G. Wilson leg.; BMNH - 1 ग; $19 \mathrm{~km} \mathrm{NE}$ of Mareeba; [coordinates of Mareeba: $16^{\circ} 59^{\prime} 42^{\prime \prime} \mathrm{S}$, $145^{\circ} 25^{\prime} 23^{\prime \prime}$ E]; 7 Jan.-12 Feb. 1985; Storey and Halfpapp leg.; interception trap; site ${ }^{\circ}$ 26; QPIM • 1 ơ; Kuranda; $16^{\circ} 49^{\prime} 11^{\prime \prime}$ S, 145³8'12" E; 28 Apr. 1957; W.W. Wirth leg.; USNM.

\section{Description}

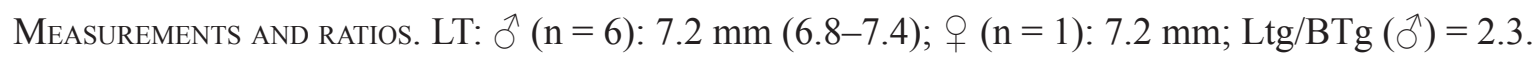

\section{Male}

HeAd (Fig. 41A-D). Vertex slightly concave, with anterior and posterior margins parallel, curved; medium to dark brown; obsolete median carina shortly marked along posterior margin. Frons uniformly coloured, medium to dark brown, sometimes darker at lateral angles. Clypeus elongate, entirely medium to dark brown. Genae brown to black with yellowish markings along anterior margin. Labium brown 
to black, reaching metacoxae. Antennae black-brown; scape short, ring-shaped; pedicel subcylindrical, slightly narrowing towards apex.

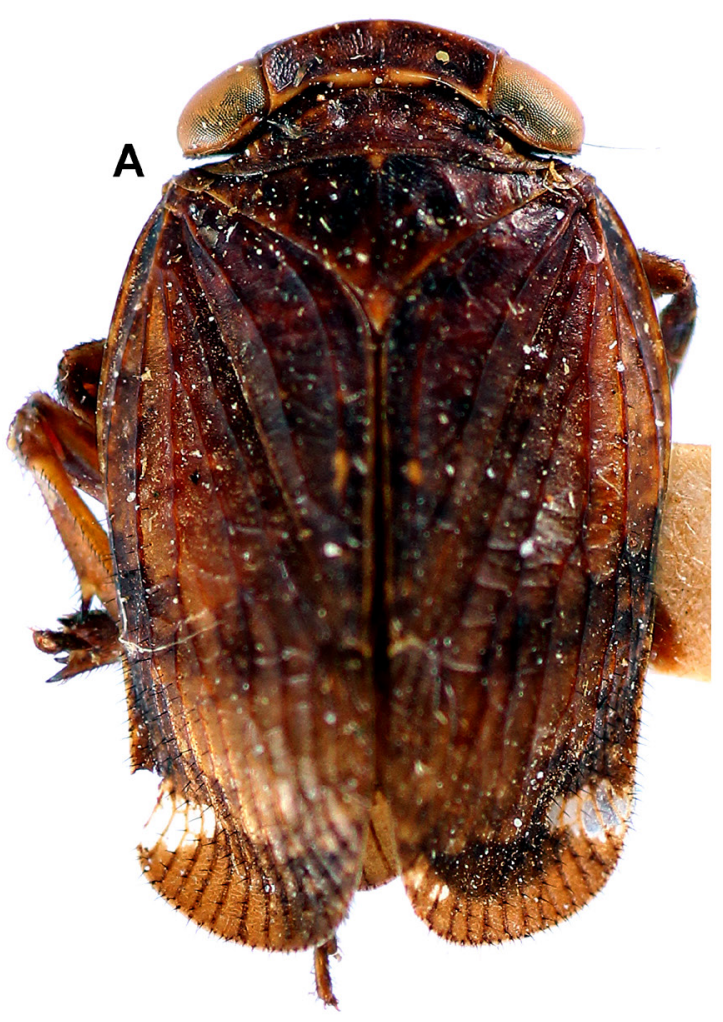

C

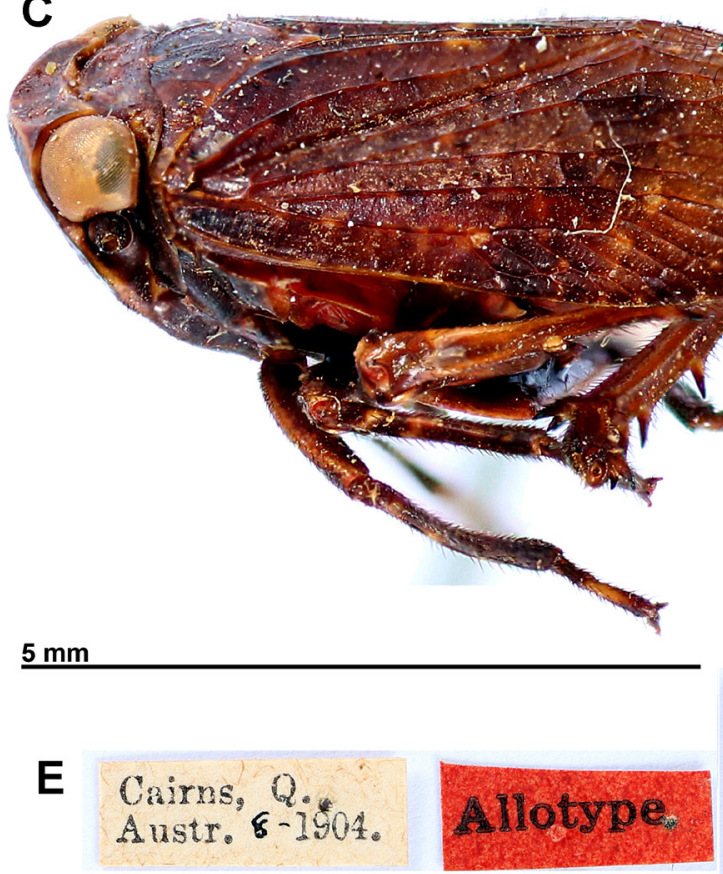

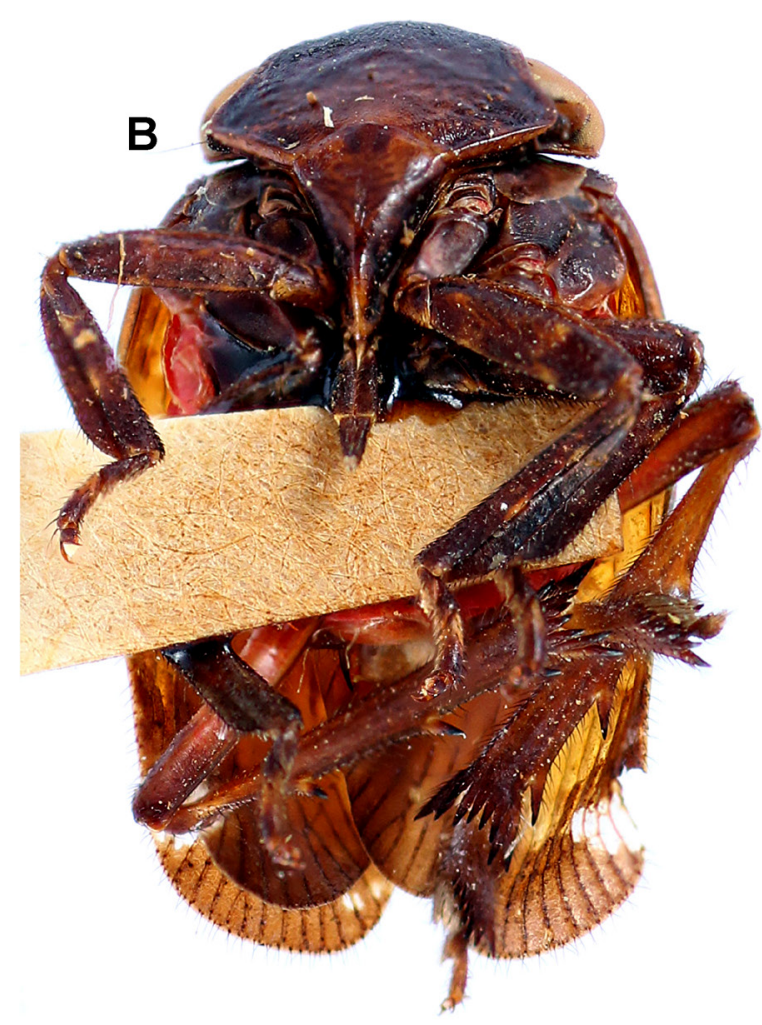

D

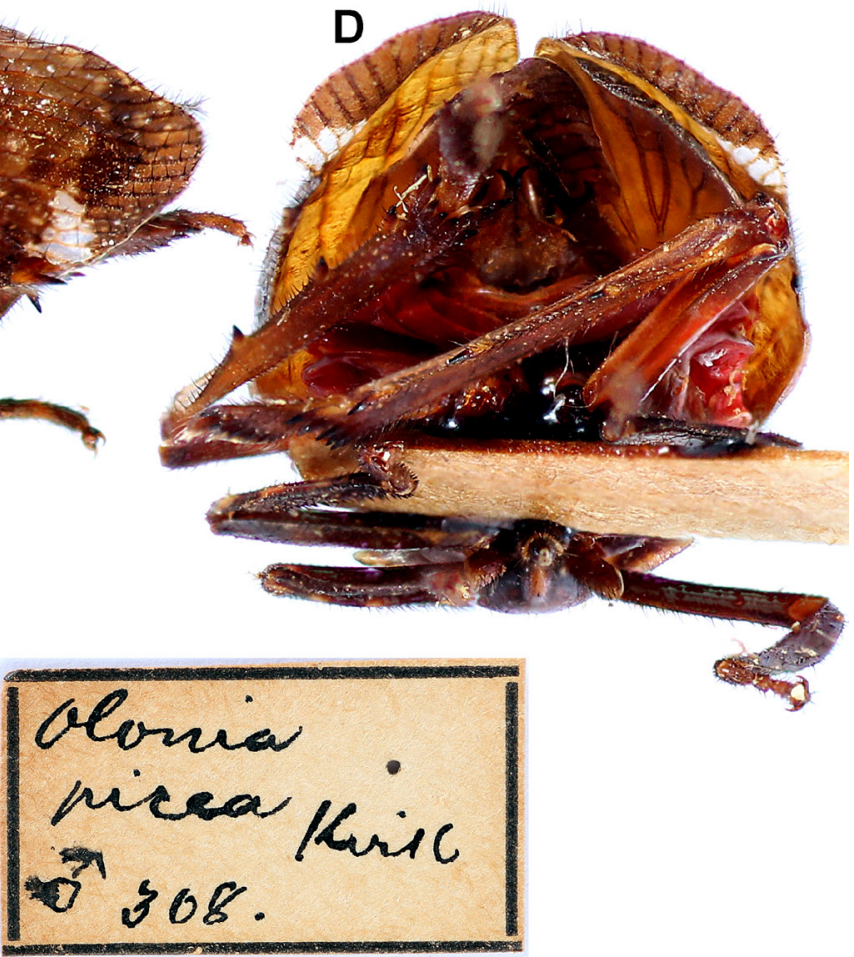

Fig. 40. Olonia picea Kirkaldy, 1906, lectotype, ô. A. Habitus, dorsal view. B. Habitus, ventral view. C. Habitus, lateral view. D. Habitus, normal view of frons. E. Labels. 
Thorax (Fig. 41A-D). Pronotum uniformly medium to dark brown; slightly wrinkled; 2 small impressed points on disc slightly marked. Lateral fields of prothorax coloured as pronotum. Mesonotum medium to dark brown variegated with darker zones on middle and sides; minute yellowish spot at apex of scutellum; median and peridiscal carinae weakly marked; median carina ending before scutellum; slight impression before scutellum. Red ventrally. Tegulae medium to dark brown.
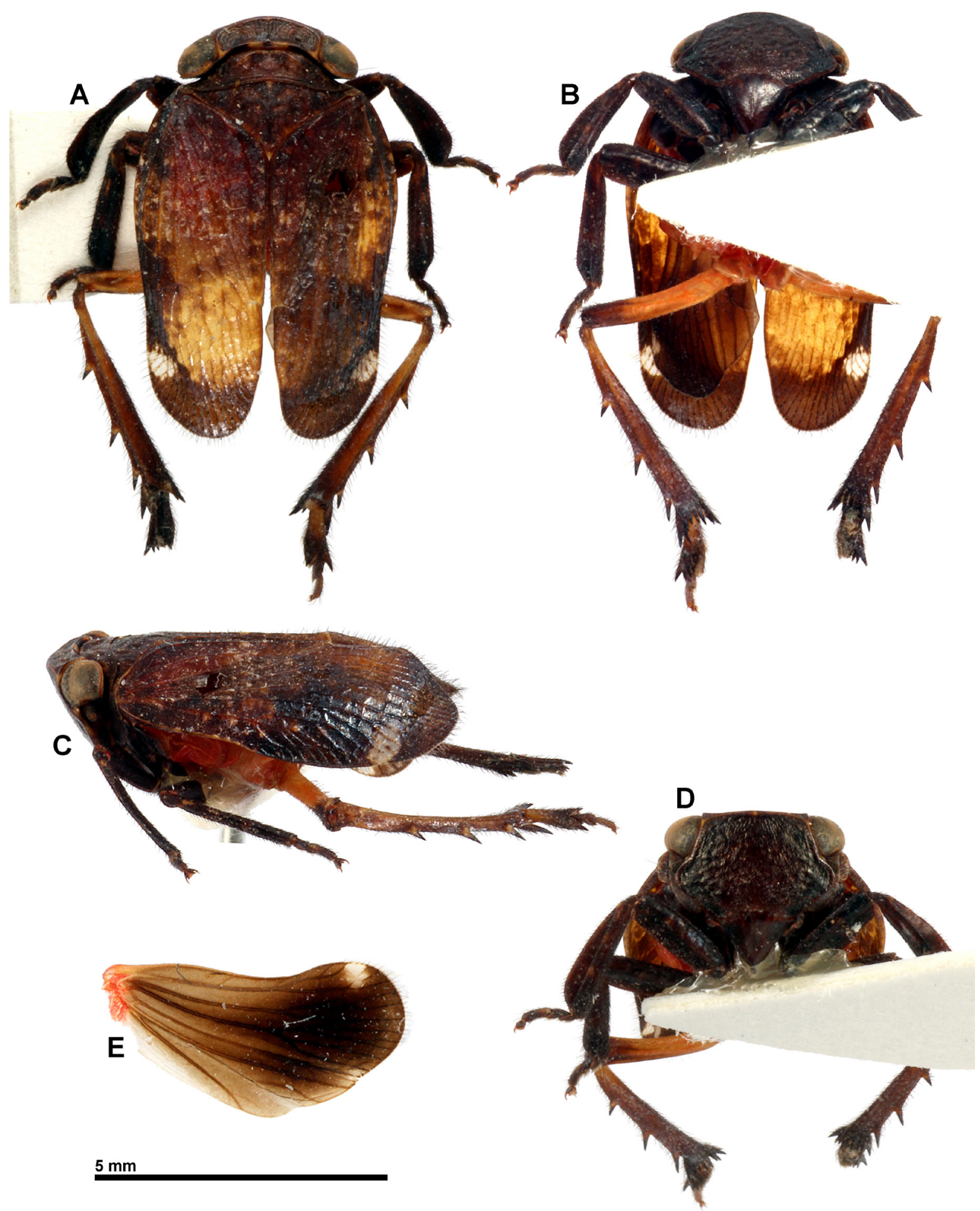

Fig. 41. Olonia picea Kirkaldy, 1906, ふૈ. A. Habitus, dorsal view. B. Habitus, ventral view. C. Habitus, lateral view. D. Habitus, normal view of frons. E. Posterior wing. 


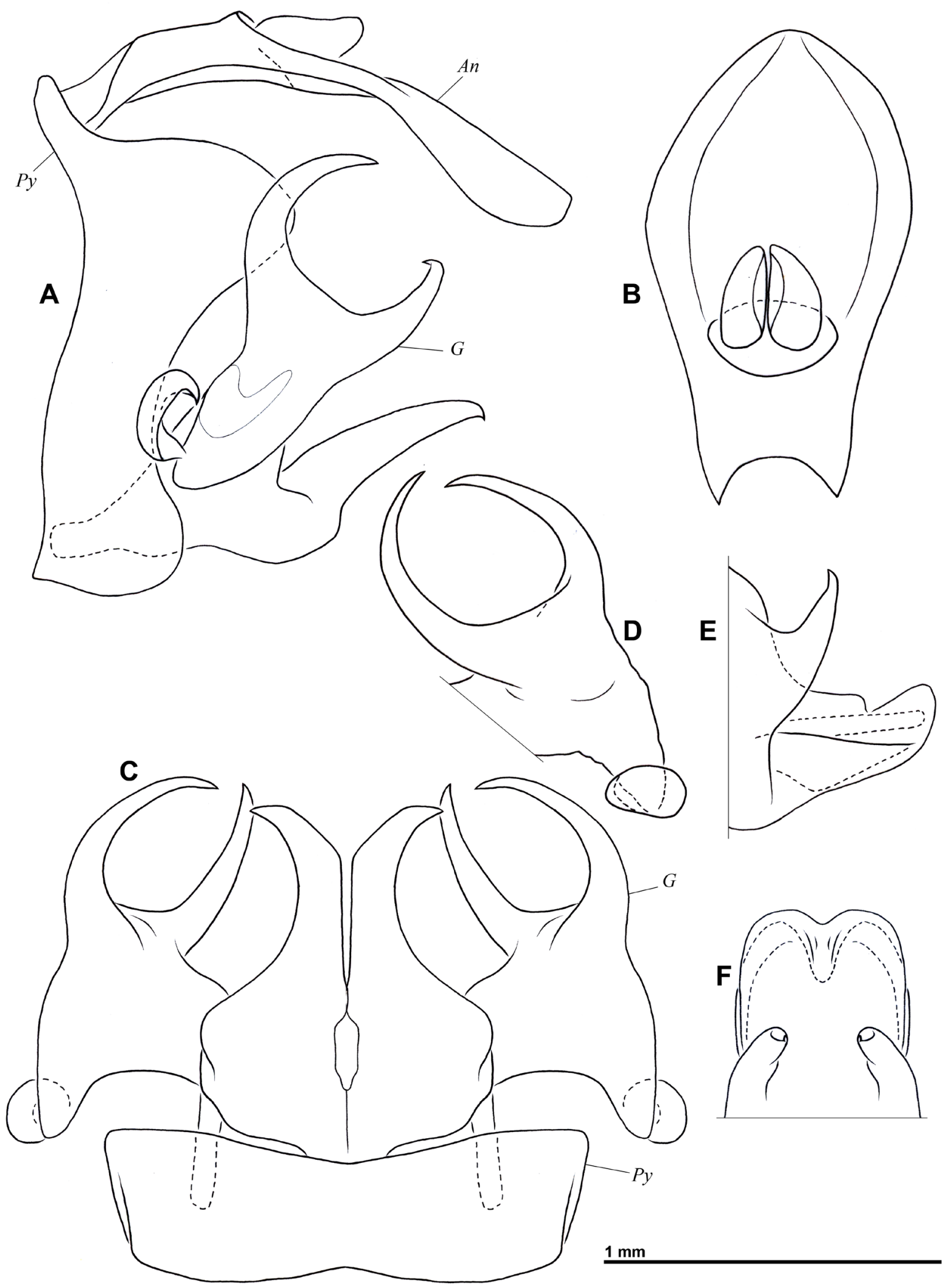

Fig. 42. Olonia picea Kirkaldy, 1906, ô, genitalia. A. Pygofer, anal tube and gonostyli, left lateral view. B. Anal tube, dorsal view. C. Pygofer and gonostyli, ventral view. D. Laterodorsal part of left gonostylus, dorsal view. E. Aedeagus, left lateral view. F. Aedeagus, dorsal view. Abbreviations: $A n=$ anal tube; $G=$ gonostyli; $P y=$ pygofer. 
Tegmina (Fig. 41A, C). Medium to dark brown; often pale yellowish marking on vein A1 at midlength of clavus; marked with dark brown or black along costal margin, more broadly so on posterior half, and along posterior margin. Often darker, median, irregular marking at apical $2 / 3$; triangular white marking on costal margin on nodal line, sometimes reduced; sometimes a number of minute white spots at
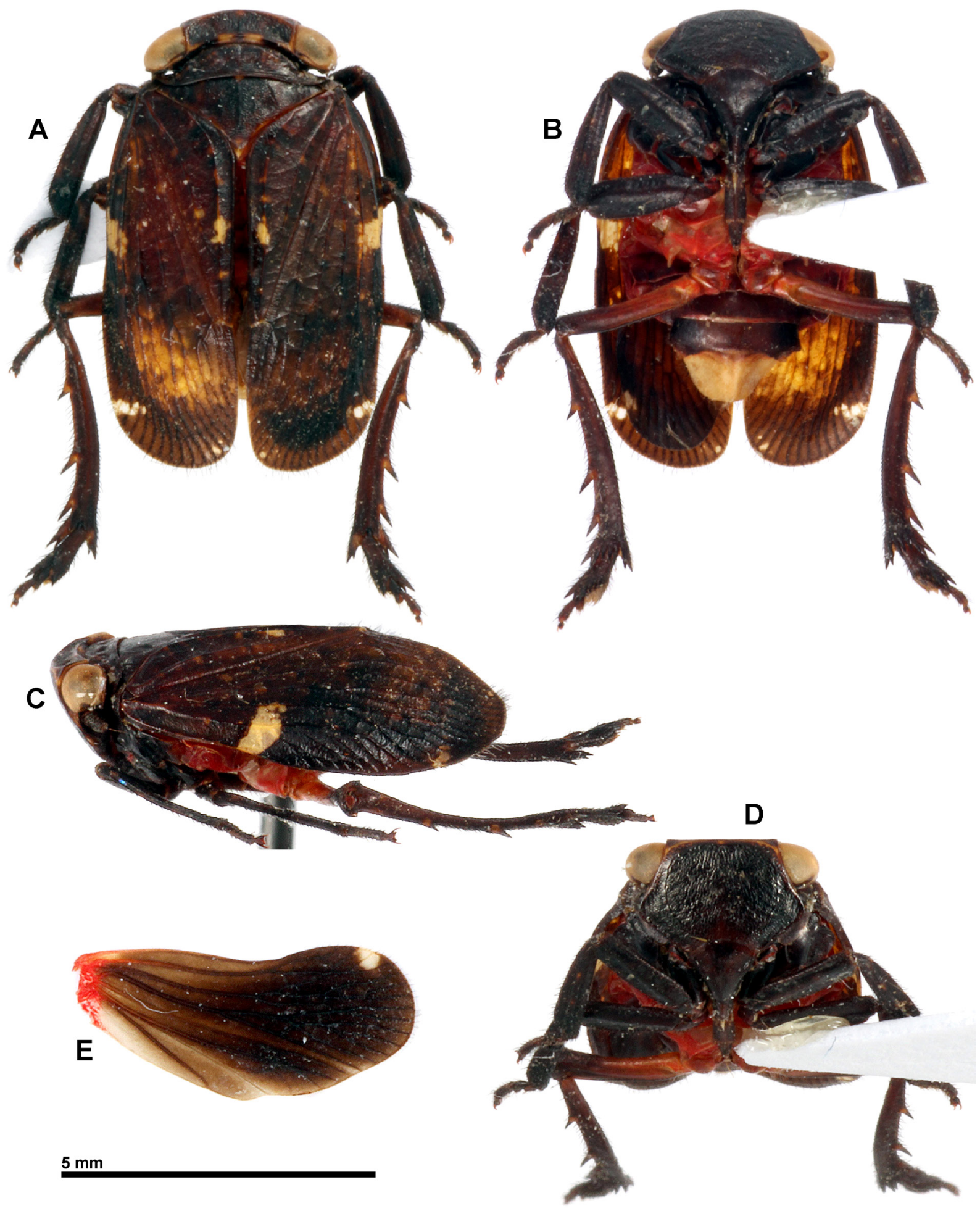

D

Fig. 43. Olonia picea Kirkaldy, 1906, ․ A. Habitus, dorsal view. B. Habitus, ventral view. C. Habitus, lateral view. D. Habitus, normal view of frons. E. Posterior wing. 
apicosutural angle. Costal and sutural margins subparallel; costal margin slightly sinuate; apical margin obliquely rounded.

Posterior wings (Fig. 41E). Brown, paler on anal area and progressively darker on apical half; small, somewhat rounded white marking at apicocostal angle, extending on 2-3 cells. Margin of anal area slightly sinuate; sutural margin with 1 slight cleft, cubital one nearly not marked.

Legs (Fig. 41A-D). Pro- and mesocoxae black-brown. Pro- and mesofemora black-brown variegated with brown. Pro- and mesotibiae medium to dark brown, sometimes with 3 paler obsolete rings. Pro- and mesotarsi black-brown, with basal half of third tarsomere paler. Metacoxae reddish; metafemora reddish with apex brown. Metatibiae brown, with 3 lateral spines paler basally and 9 apical black-brown spines. Metatarsi brown, with a ventral row of 6 black spines on first tarsomere.

AвDOMEn. Bright red with genital segments black-brown.

Male genitalia (Fig. 42). Posterior margin of pygofer in lateral view strongly sinuate, strongly roundly projecting at dorsal $1 / 3$, moderately broad ventrally (Fig. 42A, C). Anal tube obovate, 1.9 times as long as broad, narrowing at level of epiproct, slightly curved ventrally in lateral view; lateral margins slightly curved ventrally on apical half; apical margin roundly pointed (Fig. 42A-B). Gonostyli fused on basal half of length of centroventral part and projecting posteriorly (Fig. 42A, C). Centroventral part broad and dorsoventrally flattened on basal half, then narrowing into an elongate, curved, spinose process directed laterally and ending in ventrally curved point (Fig. 42A, C). Laterodorsal part of gonostyli strong and curved dorsocentrally, slightly surpassing level of centroventral part ventrally, bifid, with a dorsal and a ventral process elongate and pointing apically, and forming a $\mathrm{C}$ together; lateral process elongate, projecting posterolaterally and longer than spoon-shaped process (Fig. 42A, C-D). Dorsal portion of phallobase with hooked process on each side, progressively narrowing from base to apex, directed posterodorsally and with apex pointing centrally (Fig. 42E-F). Ventral portion of phallobase subquadrate, with apical margin emarginate in dorsal view and with median lobe not surpassing phallus (Fig. 42E-F). Phallus dorsoventrally flattened, rather broad, with apical margin emarginate in middle (Fig. 42E-F).

\section{Female}

Similar to male but with white spot on costal margin of tegmina at nodal line reduced, and sometimes with white, transverse marking on costal margin of tegmina slightly before half length and extending to vein RP (Fig. 43).

\section{Distribution and biology}

This species has been recorded from an area around Cairns in North Queensland (Fig. 3), in the Einasleigh Upland Savanna and Queensland Tropical Rainforests bioregions. Specimens were collected in January, February, March, April, July, August and September. No host plant known.

Olonia rubicunda (Walker, 1851)

Figs 3, 44

Eurybrachys rubicunda Walker, 1851: 391 (described).

Eurybrachys rubicunda - Kirkaldy 1906: 445 (listed as belonging to Olonia).

Olonia rubicunda - Stål 1862: 488 (transferred to Olonia). — Distant 1906: 206 (type species of Olonia). — Metcalf 1956: 65 (catalogued).

non Olonia rubicunda - Jacobi 1928: 4 ((re)described from Kimberley District (erroneous, based on misidentified specimens)). — Lallemand 1935: 675 (mentioned from Northern Territory (erroneous, based on misidentified specimens)). 


\section{Diagnosis}

The species can be recognized by the following combination of characters ( $($ ):

(1) hind wings without orange marking (Fig. 44B)

(2) pro- and mesofemora and tibiae largely black-brown (Fig. 44C, E)

(3) tegmina brown, darker along costal and apical margins (Fig. 44B)

(4) rather small size: $8.5 \mathrm{~mm}$

This species is currently known only from a single female and the diagnosis will need to be augmented with characters of the male genitalia when male specimens become available.

\section{Etymology}

The species epithet rubicundus (adjective, Latin) means 'bright red'. It refers to the colour of the abdomen in this species.

\section{Material examined}

\section{Holotype}

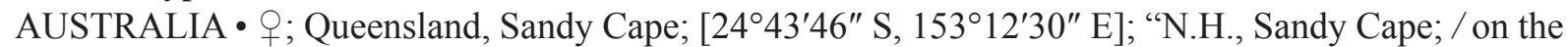
reverse / 46 73", "Type", "22. Eurybracbys [sic] rubicunda", "Re-pinned on stainless"; left anterior and posterior, and right median legs glued on labels attached to the pin of the specimen, left tegmen missing; BMNH (Fig. 44).

\section{Note}

"N.H." on the first label stands for New Holland, a former name for Australia.

\section{Description}

MEASUREMENTS AND RATIOs. LT: $q(\mathrm{n}=1): 8.5 \mathrm{~mm}$ (extrapolated); $\mathrm{BV} / \mathrm{LV}=4.25 ; \mathrm{BF} / \mathrm{LF}=1.76 ; \mathrm{LP}+\mathrm{LM} / \mathrm{BT}$ not measurable; $\mathrm{LTg} / \mathrm{BTg}=2.5 ; \mathrm{LW} / \mathrm{BW}$ not measurable.

\section{Female}

HEAD (Fig. 44A-E). Vertex concave, with anterior and posterior margins parallel, curved; brown with darker marking at lateral angles. Frons uniformly reddish brown. Clypeus elongate, entirely reddish brown. Genae yellowish with elongate brown marking under eye. Labium black-brown, reaching metacoxae. Antennae black-brown; scape short, ring-shaped; pedicel subcylindrical, slightly narrowing towards apex.

Thorax (Fig. 44A-E). Pronotum brown and slightly wrinkled; obsolete median carina and 2 small impressed points on disc. Lateral fields of prothorax brown. Mesonotum brown variegated with blackish; peridiscal carinae weakly marked. Red ventrally. Tegulae brown. (Mesonotum damaged in the examined specimen.)

Tegmina (Fig. 44B). Brown with small yellowish spots; pale yellowish marking on vein A1 at $2 / 3$ of clavus; marked with black along costal margin, more broadly so on posterior half, and along posterior margin. Triangular white marking on costal margin on nodal line; yellowish markings at apicosutural angle. (Remaining right tegmen of examined specimen damaged.)

Posterior wings (Fig. 44B). Brown, paler on anal area and with large darker area reaching apical margin; elongate, transverse, subtriangular white marking at apicocostal angle, extending on 3 cells. Margin of anal area slightly sinuate; sutural margin with 1 cleft, cubital one not marked. 


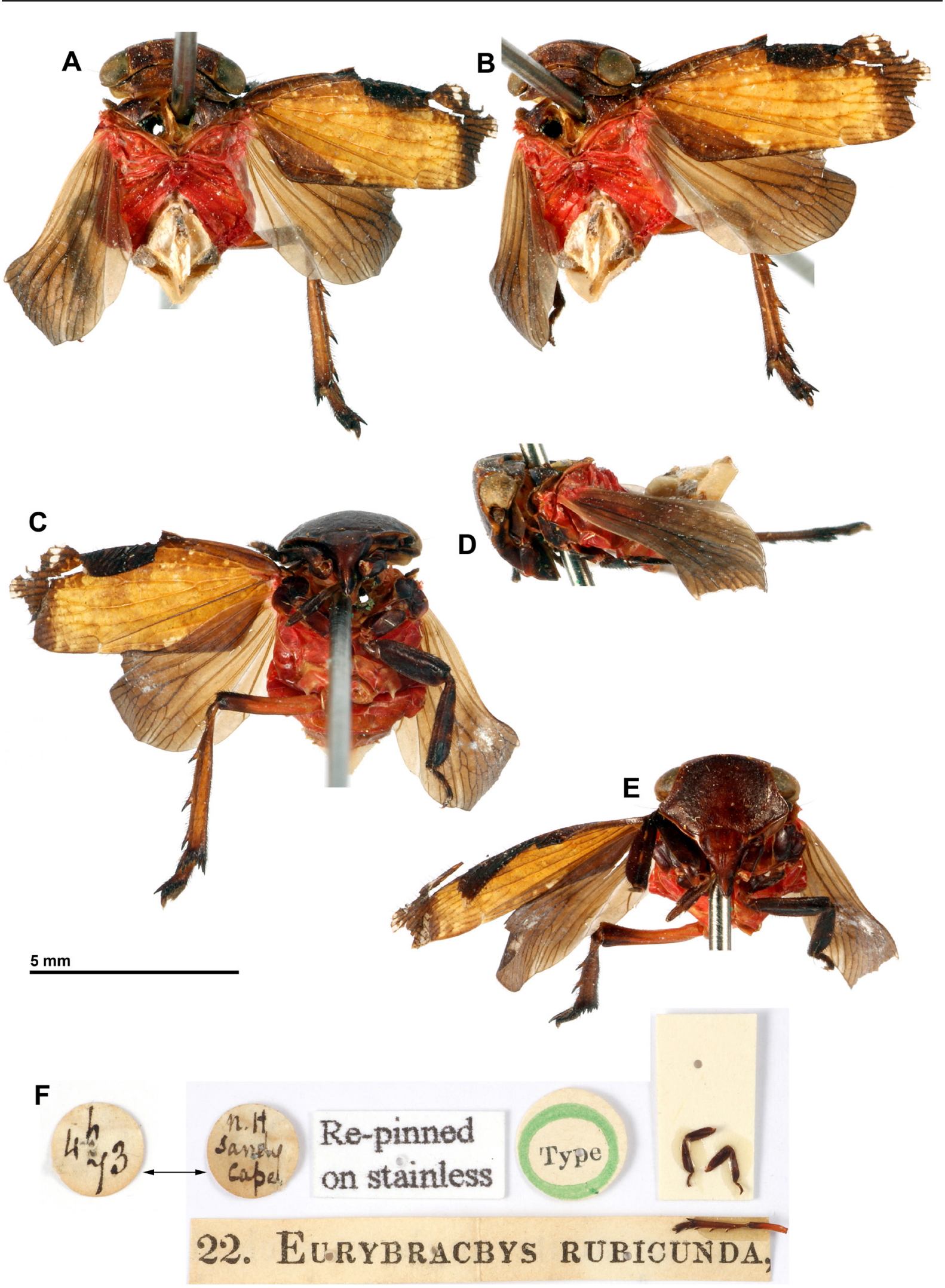

Fig. 44. Olonia rubicunda (Walker, 1851), holotype, ․ A. Habitus, dorsal view. B. Habitus, normal view of right tegmen. C. Ventral view. D. Habitus, lateral view. E. Habitus, normal view of frons. F. Labels (with three legs). 
Legs (Fig. 44A, C, E). Pro- and mesocoxae dark brown. Pro- and mesofemora black-brown with reddish spots marking obsolete rings. Pro- and mesotibiae black-brown with reddish markings on 3 obsolete rings. Pro- and mesotarsi black-brown, with basal half of third tarsomere paler. Metacoxae red; metafemora reddish with apex brown. Metatibiae brown, with 3 lateral spines paler basally and 8 apical black-brown spines. Metatarsi brown, with a ventral row of 6 black spines on first tarsomere.

Aвdomen (Fig. 44A-D). Bright red with genital segments brown and sternite VII white.

\section{Male \\ Unknown.}

\section{Distribution and biology}

This species is known only from a single specimen from Fraser Island in southeastern Queensland (Fig. 3), in the Eastern Australian Temperate Forests bioregion. Biology unknown.

Olonia rylandae sp. nov. urn:Isid:zoobank.org:act:1F0498E0-6DD9-48AD-AB8D-2369364963CE

Figs 3, 45-46

\section{Diagnosis}

This species can be recognized by the following combination of characters:

(1) hind wings without orange marking (Fig. 45E)

(2) pro- and mesofemora and -tibiae mostly brown (Fig. 45A-D)

(3) anal tube of male oblong, with posterior margin slightly concave and lateral margins sinuate (Fig. 46B)

(4) centroventral part of gonostyli with elongate and narrow process strongly sinuate basally and with small apical hook pointing ventrally (Fig. 46A, C)

(5) laterodorsal part of gonostyli with elongate and narrow process slightly curved lateroventrally (Fig. 46A, C-D)

(6) rather small size: $7.7 \mathrm{~mm}$

\section{Etymology}

This species is dedicated to Mrs Valry Ryland (Magnetic Island, Queensland, Australia) in acknowledgement for all her help and involvement in documenting the natural history of species of Olonia.

\section{Material examined}

\section{Holotype}

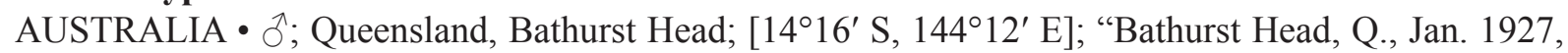
Hale \& Tindale"; dissected, right anterior leg missing, right posterior wing mounted; SAM.

\section{Description}

Measurements and Ratios. LT: $\widehat{\delta}(\mathrm{n}=1): 7.7 \mathrm{~mm} ; \mathrm{BV} / \mathrm{LV}=4.38 ; \mathrm{BF} / \mathrm{LF}=1.7 ; \mathrm{LP}+\mathrm{LM} / \mathrm{BT}=0.67$; $\mathrm{LTg} / \mathrm{BTg}=2.5 ; \mathrm{LW} / \mathrm{BW}=2.0$.

\section{Male}

HEAD (Fig. 45A-D). Vertex concave, with anterior and posterior margins parallel, curved; brown, slightly wrinkled. Frons uniformly brown, slightly wrinkled. Clypeus elongate, brown. Genae yellowish with brown markings around eyes and under antennae. Labium dark brown, reaching metacoxae. Antennae black-brown; scape short, ring-shaped; pedicel subcylindrical, slightly narrowing towards apex. 

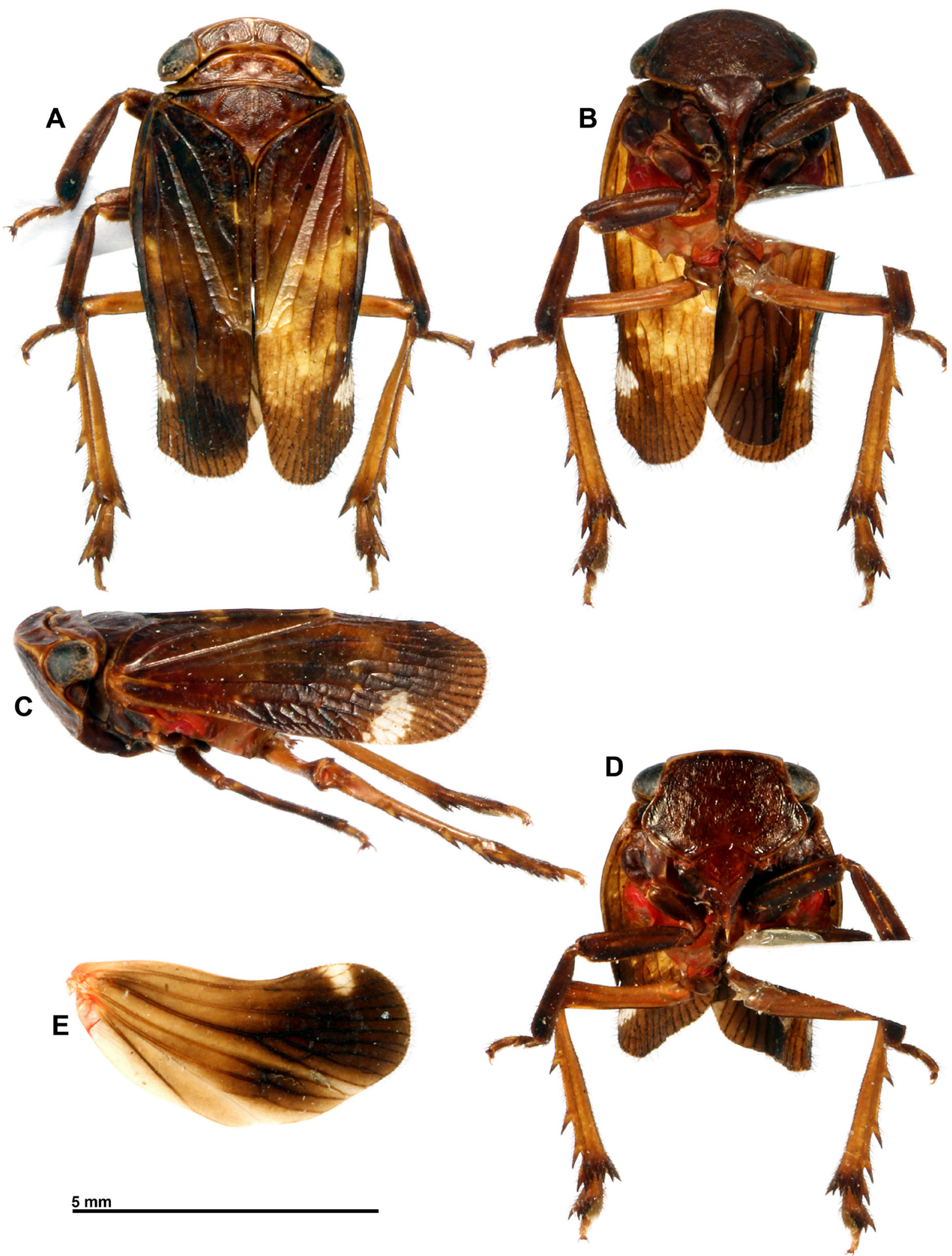

Fig. 45. Olonia rylandae sp. nov., holotype, $\widehat{\jmath}$. A. Habitus, dorsal view. B. Habitus, ventral view. C. Habitus, lateral view. D. Habitus, normal view of frons. E. Posterior wing. 
Thorax (Fig. 45A-C). Pronotum brown with small yellowish spot on each side; slightly wrinkled; obsolete median carina and 2 small impressed points on disc. Lateral fields of prothorax brown. Mesonotum brown; yellowish spot on middle of anterior margin and at apex of scutellum; slightly rugulose; median and peridiscal carinae weakly marked; median carina stopping before scutellum; slight impression before scutellum. Red ventrally. Tegulae brown.

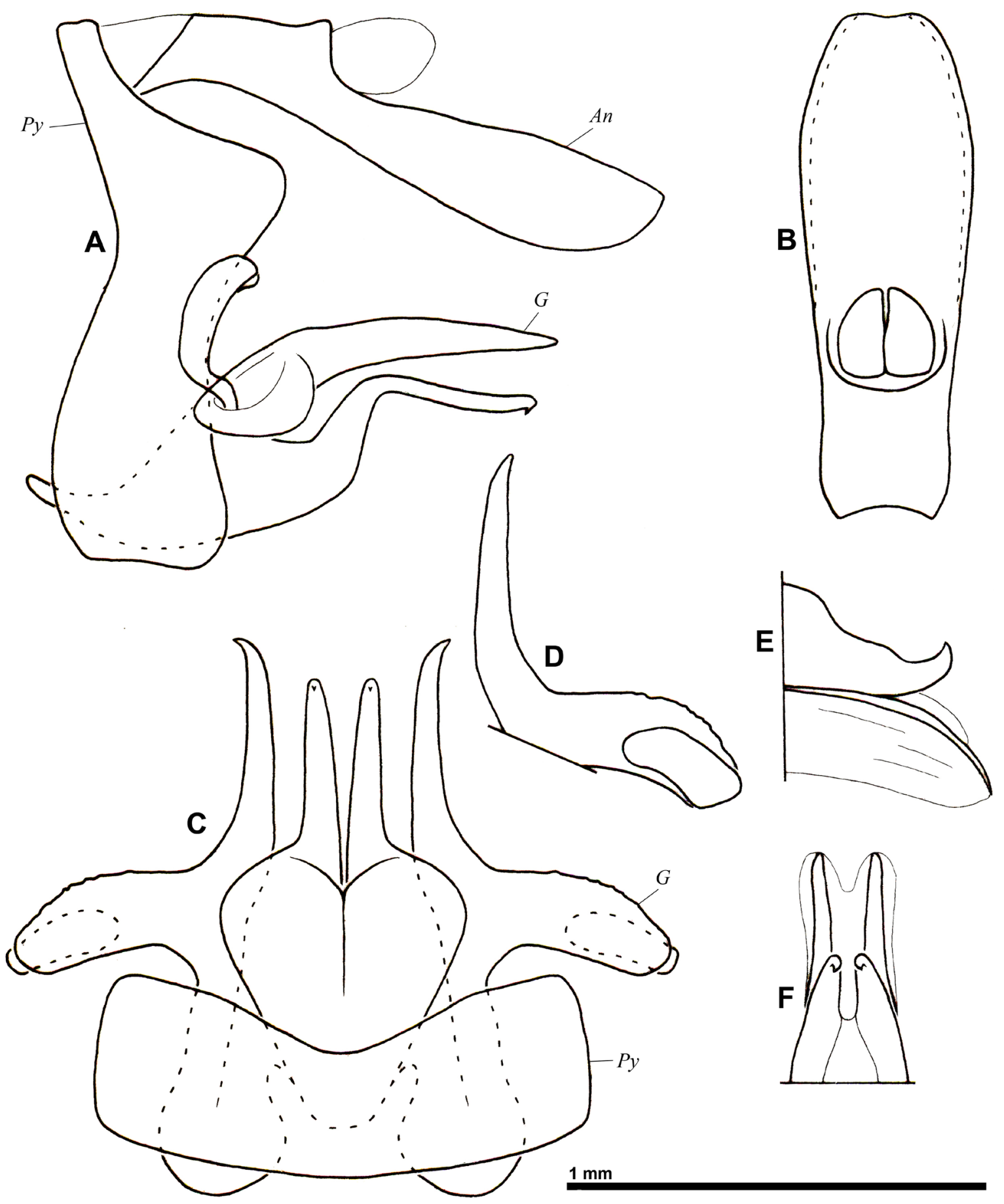

Fig. 46. Olonia rylandae sp. nov., holotype, $\hat{\jmath}$, genitalia. A. Pygofer, anal tube and gonostyli, left lateral view. B. Anal tube, dorsal view. C. Pygofer and gonostyli, ventral view. D. Laterodorsal part of left gonostylus, dorsal view. E. Aedeagus, left lateral view. F. Aedeagus, dorsal view. Abbreviations: $A n=$ anal tube $G=$ gonostyli; $P y=$ pygofer. 
TEgmina (Fig. 45A, C). Brown, slightly variegated with yellowish; pale yellowish marking on vein A1 at midlength of clavus; marked with black along costal margin, more broadly so on posterior half, and along posterior margin. Triangular white marking on costal margin on nodal line; no white spot at apicosutural angle. Costal and sutural margins subparallel; costal margin slightly sinuate; apical margin obliquely rounded.

Posterior wings (Fig. 45E). Brown, paler on anal area and with large blackish area reaching apical margin; elongate, transverse, subtriangular white marking at apicocostal angle, extending on 3-4 cells. Margin of anal area slightly sinuate; sutural margin with 1 cleft, cubital one nearly not marked.

Legs (Fig. 45A-D). All coxae brown. Pro- and mesofemora dark brown. Pro- and mesotibiae brown, turning blackish apically, and with 3 very obsolete paler rings. Pro- and mesotarsi brown, with basal half of third tarsomere paler. Metafemora pale brown with apex darker. Metatibiae brown, with 3 lateral spines paler basally and 8 apical black-brown spines. Metatarsi brown, with a ventral row of 6 black spines on first tarsomere.

AвDOMEn. Bright red with genital segments black-brown.

Male Genitalia (Fig. 46). Posterior margin of pygofer in lateral view strongly sinuate, rather angularly, roundly projecting at dorsal $1 / 3$ and rather broad ventrally (Fig. 46A, C). Anal tube oblong, 2.9 times as long as broad, broader at apical $2 / 3$, with lateral margins sinuate and apical margin concave; lateral margins curved ventrally on apical $2 / 3$; slightly curved ventrally near base in lateral view (Fig. 46A-B). Gonostyli fused on slightly less than basal half of length of centroventral part and projecting posteriorly (Fig. 46A, C). Centroventral part broad and dorsoventrally flattened on basal half, then strongly narrowing into elongate, narrow process, strongly sinuate basally in lateral view and ending in narrow hook curved anteroventrally (Fig. 46A, C). Laterodorsal part of gonostyli elongate and slightly curved posteroventrally, posteriorly slightly surpassing level of centroventral part; lateral process elongate, projecting posterolaterally, slightly concave dorsally and longer than spoon-shaped process (Fig. 46A, C-D). Dorsal portion of phallobase with hooked process on each side, narrowing in 2 steps from base to apex, directed posterocentrally and with apex pointing dorsally (Fig. 46E-F). Ventral portion of phallobase elongate and narrow, curved posteroventrally (Fig. 46E-F). Phallus dorsoventrally flattened, medially concave, broadening towards apex and emarginate apically (Fig. 46E-F).

\section{Female}

Unknown.

\section{Distribution and biology}

This species is only known from a single male from Bathurst Head, a headland covered with open forest close to Cape Melville on the eastern coast of Cape York Peninsula (Fig. 3), in the Cape York Peninsula Tropical Savanna bioregion. It was collected in January, nearly one century ago.

Olonia soulierae sp. nov.

urn:1sid:zoobank.org:act:6670A1E7-F89F-4D93-901E-49DD861B6539

Figs 3, 47-49

\section{Diagnosis}

This species can be recognized by the following combination of characters:

(1) hind wings with orange marking (Figs 47E, 49E)

(2) pro- and mesofemora and -tibiae largely black-brown (Figs 47A-D, 49A-D)

(3) anal tube of male narrow and parallel-sided on basal $1 / 3$, then ovate with posterior margin notched (Fig. 48B) 
(4) centroventral part of gonostyli with long and narrow process, slightly sinuate basally and with apical hook pointing dorsally (Fig. 48A, C)

(5) laterodorsal part of gonostyli with hooked process curved lateroventrally (Fig. 48A, C-D)

(6) large size: $9.4-11.2 \mathrm{~mm}$

\section{Etymology}

This species is dedicated to Dr Adeline Soulier-Perkins (MNHN), who collected a part of the type series.

\section{Material examined}

Holotype

AUSTRALIA • $\mathrm{O}^{\lambda}$; Queensland, near Chillagoe Haunted Cave; $17^{\circ} 06^{\prime} \mathrm{S}, 144^{\circ} 25^{\prime}$ E; "Muséum Paris, Australie (Queensland) Près de Chilagoe Hounted Cave - Cave 1", "S1706' E144²5', 13.III.1997, A. Soulier-Perkins \& Th. Bourgoin rec..”, "QM-244702”; QM.

\section{Paratypes}

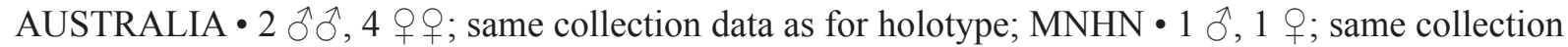
data as for holotype; RBINS • 1 \%; "Australia: Qld., Chillagoe Caves Nat. Park, turnoff to Royal Arch Cave, Au 97 - 49, 60, 63, M. Asche \& H. Hoch, 19.III.1997”; ZMHB.

\section{Description}

MEAsurements and Ratios. LT: $\hat{\jmath}(\mathrm{n}=3): 9.8 \mathrm{~mm}(9.4-10.1)$; ㅇ $(\mathrm{n}=5): 10.8 \mathrm{~mm}(10.5-11.2)$; $\mathrm{BV} / \mathrm{LV}=4.0 ; \mathrm{BF} / \mathrm{LF}=1.71 ; \mathrm{LP}+\mathrm{LM} / \mathrm{BT}=0.71 ; \mathrm{LTg} / \mathrm{BTg}=2.1-2.3 ; \mathrm{LW} / \mathrm{BW}=1.72$.

\section{Male}

HEAD (Fig. 47A-D). Vertex concave, with anterior and posterior margins parallel, curved; dark brown variegated with yellowish in middle. Frons black-brown, slightly tinged with 2 transverse, irregular, variegated yellowish markings, more dorsal one not reaching sides. Clypeus elongate, dark reddish brown with 2 short, black, longitudinal lines at base, with apex darker. Genae yellowish with brown markings around eyes and under antennae. Labium brown, reaching metacoxae. Antennae black; scape short, ring-shaped; pedicel subcylindrical, slightly narrowing towards apex.

Thorax (Fig. 47A-C). Pronotum dark brown with some yellowish markings laterally; slightly transversely wrinkled posteriorly; obsolete median carina and 2 small impressed points on disc. Lateral fields of prothorax brown. Mesonotum dark brown with reddish markings along posterior margin, median yellowish spot along anterior margin and at apex of scutellum; slightly rugulose; median and peridiscal carinae weakly marked; median carina ending before scutellum; slight impression before scutellum. Red ventrally. Tegulae brown.

Tegmina (Fig. 47A, C). Dark brown with small yellowish or reddish spots; bigger, whitish, slightly transverse spot on middle of clavus; large triangular white marking on costal margin on nodal line and a smaller one anterior to it; white marking at apicosutural angle. Maximum breadth at nodal line; costal margin slightly sinuate; apical margin obliquely rounded.

Posterior wings (Fig. 47E). Brown with apical $1 \frac{1}{3}$ black-brown; transverse, subtriangular white marking at apicocostal angle, extending on 5 cells; sutural margin broadly bordered with yellowish on basal half; orange marking between anal fold and vein $\mathrm{CuA}$ at about half length. Margin of anal area sinuate; sutural margin with 2 clefts, cubital one slightly marked.

Legs (Fig. 47A-D). Pro- and mesocoxae reddish brown. Pro- and mesofemora black-brown with yellowish spots marking 2 obsolete rings. Pro- and mesotibiae black-brown with 3 obsolete ring-shaped yellowish markings, larger one near apex. Pro- and mesotarsi dark brown, with basal half of last segment 

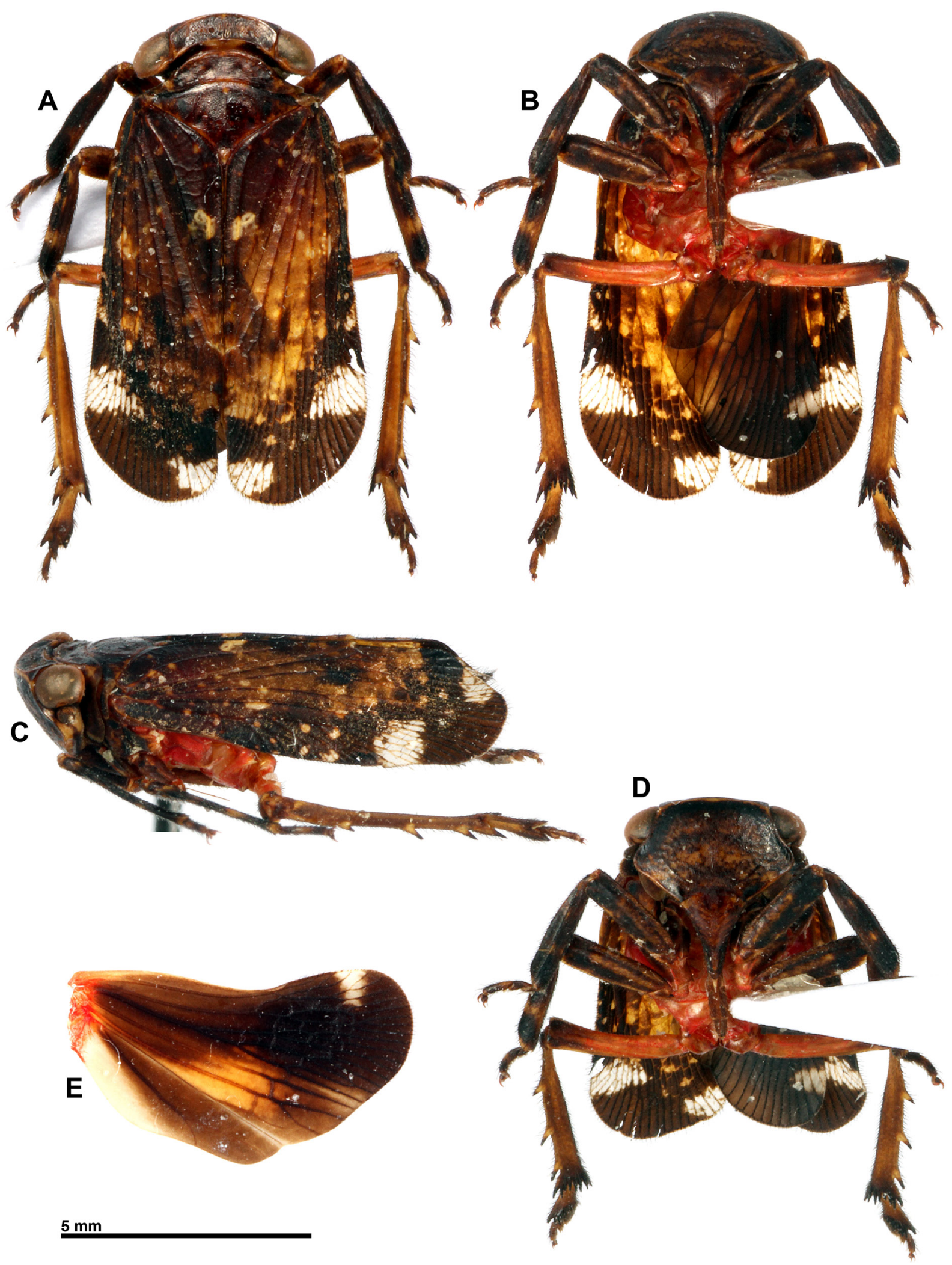

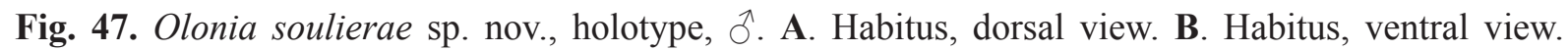
C. Habitus, lateral view. D. Habitus, normal view of frons. E. Posterior wing. 
yellow-brown. Metacoxae reddish; metafemora reddish with apex brown. Metatibiae brown, with 3 lateral spines yellowish basally and 8 apical, black-brown spines. Metatarsi brown with a ventral row of 6 black spines on first tarsomere.

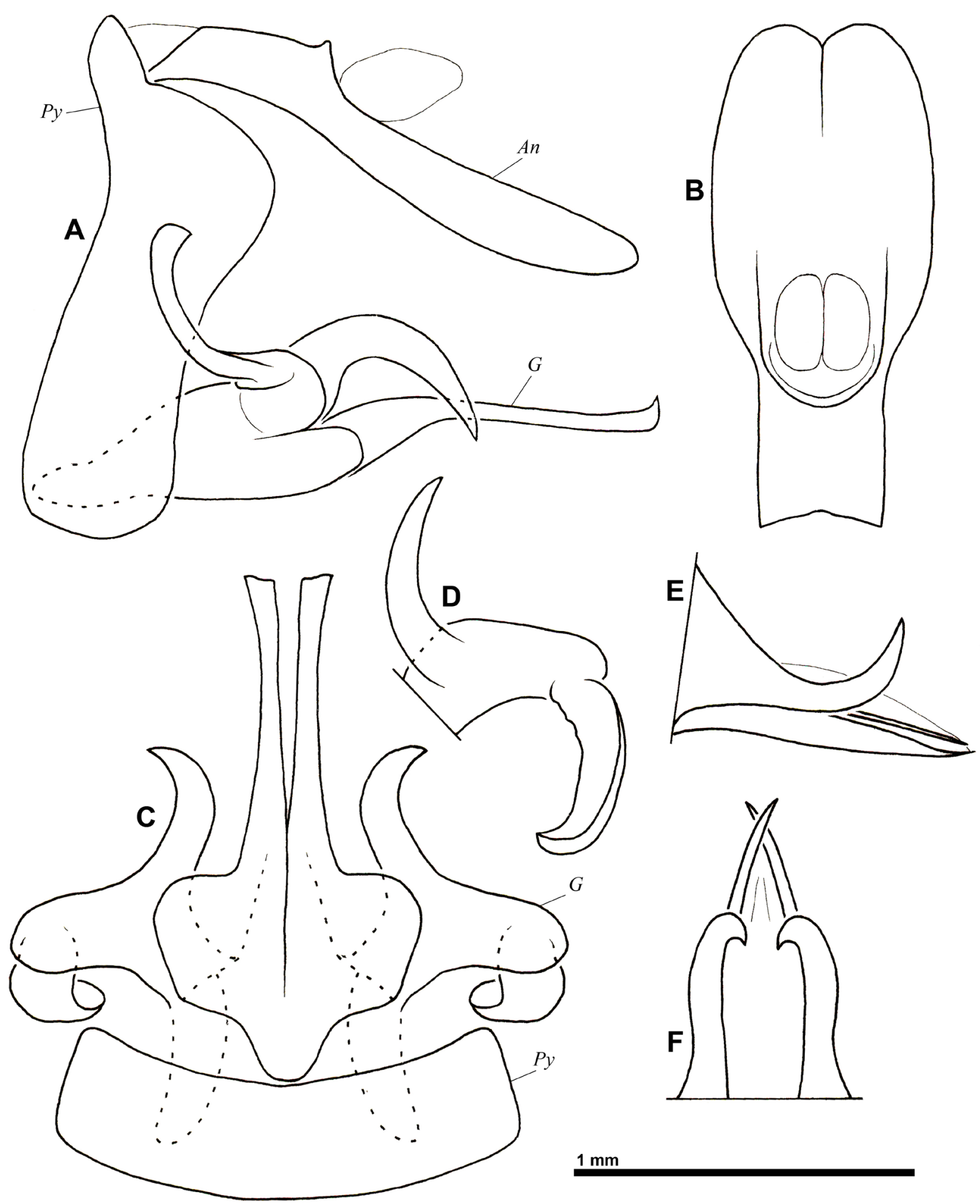

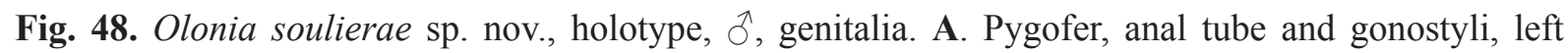
lateral view. B. Anal tube, dorsal view. C. Pygofer and gonostyli, ventral view. D. Laterodorsal part of left gonostylus, dorsal view. E. Aedeagus, left lateral view. F. Aedeagus, dorsal view. Abbreviations: $A n=$ anal tube $G=$ gonostyli; $P y=$ pygofer. 
AвDOMEn. Bright red with genital segments black-brown.

MALE GENITAliA (Fig. 48). Posterior margin of pygofer in lateral view strongly sinuate, roundly projecting at dorsal $1 / 3$, rather broad ventrally (Fig. 48A, C). Anal tube elongate, 2.25 times as long as broad, with
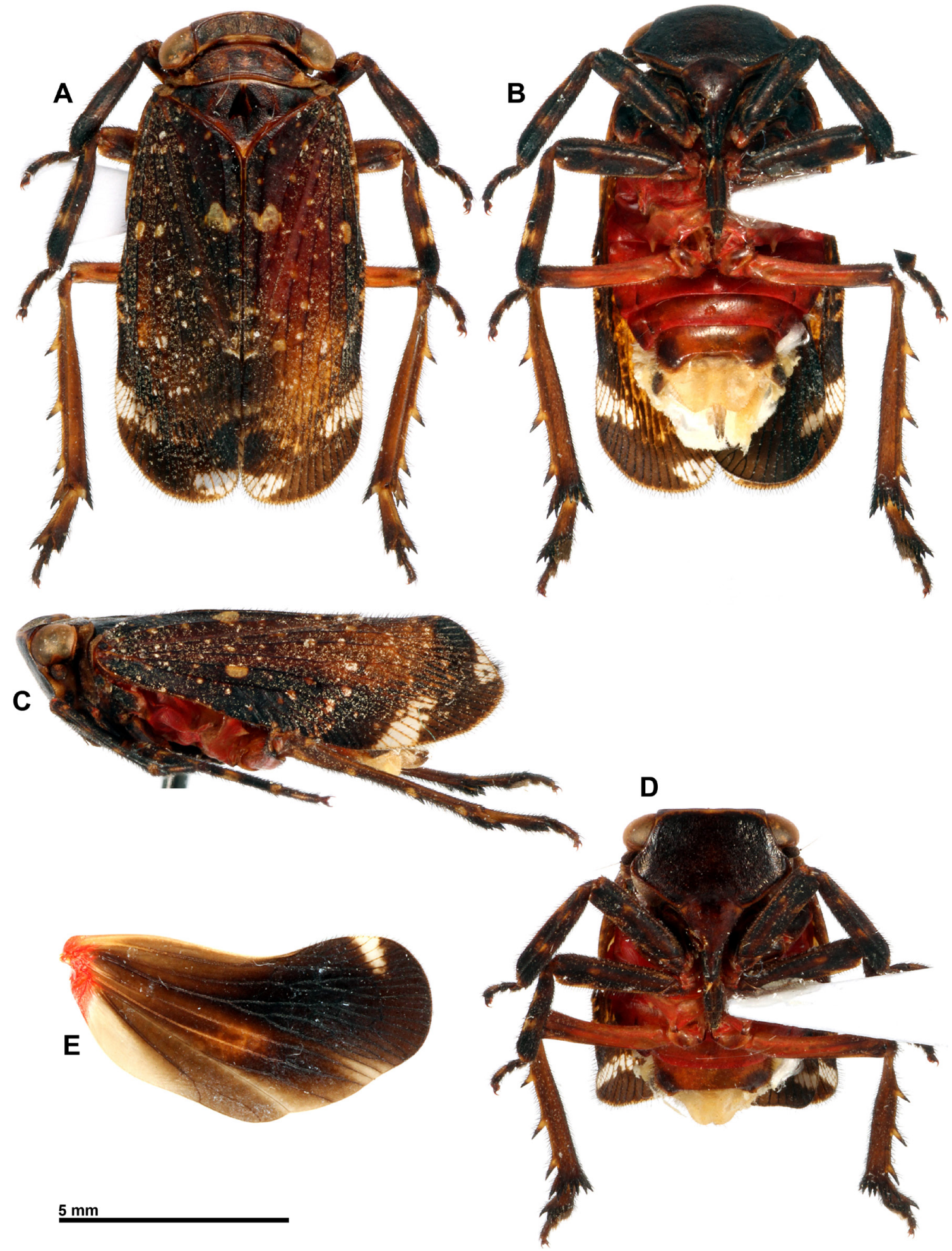

Fig. 49. Olonia soulierae sp. nov., paratype, ${ }_{\text {+ }}$ A. Habitus, dorsal view. B. Habitus, ventral view. C. Habitus, lateral view. D. Habitus, normal view of frons. E. Posterior wing. 
basal $1 / 3$ parallel-sided and narrower, then broadly ovate with posterior margin notched; slightly sinuate in lateral view; lateral margins slightly curved ventrally on apical $2 / 3$ (Fig. 48A-B). Gonostyli fused to nearly half length of centroventral part and projecting posteriorly (Fig. 48A, C). Centroventral part dorsoventrally flattened on basal $1 / 3$, then abruptly narrowing and forming strongly elongated and narrow process, slightly diverging and ending in a small hook pointing dorsally; process slightly sinuate in lateral view (Fig. 48A, C). Laterodorsal part of gonostyli curved lateroventrally, hooked, with lateral process rather broad and moderately elongated, about as long as spoon-shaped process (Fig. 48A, C-D). Dorsal portion of phallobase with elongate process on each side, strongly narrowing on basal half in lateral view, then strongly hooked, pointing dorsally and slightly incurved (Fig. 48E-F). Ventral portion of phallobase along lateral margin of phallus on basal half, elongate and supassing phallus, crossing after it (Fig. 48E-F). Phallus dorsoventrally flattened, elongate, narrowing from base to apex (Fig. 48E-F).

\section{Female}

Similar to male, but darker; frons entirely black-brown; white markings on tegmina smaller; blackbrown area of posterior wings larger, orange marking reduced (Fig. 49).

\section{Distribution and biology}

This species is known from a series of ten specimens collected in Chillagoe in North Queensland (Fig. 3), in the Einasleigh Upland Savanna bioregion. Nine specimens were collected on a single day in March; hence, the species is probably not scarce in its habitat. No host plant is recorded.

Genus Stalobrachys gen. nov. urn:lsid:zoobank.org:act:7BB4E8DC-4BF9-4A5B-B653-76EC7BD66201

Figs $50-51$

\section{Type species}

Olonia alboapicata Jacobi, 1928, here designated.

\section{Diagnosis}

Rather small sized $(8.5-10 \mathrm{~mm})$, dark brown variegated with black and yellowish, tegmina with a white marking along costal margin on nodal line and posterior wings usually with a white marking near externoapical angle in males and with apex white in females. The genus can be recognized by the following set of characters:

(1) posterior wings with anal area well developed, broad (LW/BW =1.5) (Fig. 50A)

(2) posterior margin of pygofer with strongly developed projection at laterodorsal angle

(3) gonostyli moderately sclerified, separated and with elongate basodorsal process bearing dorsoapical, articulate, spoon-shaped process

(4) aedeagus reduced, with dorsal portion of phallobase bearing two convergent elongate spinose processes

The genus shares having a spoon-shaped process on the gonostyli with the Australian genera Chewobrachys Constant, 2008, Fletcherobrachys Constant, 2006, Hackerobrachys Constant, 2006, Maeniana Metcalf, 1952, Nirus Jacobi, 1928 and Olonia Stål, 1862, but differs

- from Chewobrachys by the smaller size ( $8.5-10 \mathrm{~mm} ; 12-16 \mathrm{~mm}$ in Chewobrachys), the dark brown colour (greyish brown in Chewobrachys) and the male gonostyli with an elongate basodorsal process (gonostyli without basodorsal process in Chewobrachys)

- from Fletcherobrachys by the bright red abdomen (green to orange in Fletcherobrachys), the hind wings being brown with a (sub-)apical white marking (basal half white in Fletcherobrachys), the absence of sexual dimorphism on the median tibiae (median tibiae with externodistal process in females of 
Fletcherobrachys) and the male gonostyli separated and with an elongate basodorsal process (gonostyli fused along most of their length and without a basodorsal process in Fletcherobrachys)

- from Hackerobrachys by the frons being brown and slightly convex (bright yellow to red and strongly convex in Hackerobrachys), the posterior wings being brown with a (sub-)apical white marking and rounded apically (uniformly brown with apex subquadrate in Hackerobrachys) and the gonostyli being separated, with an elongate basodorsal process (gonostyli fused along most of their length and without a basodorsal process in Hackerobrachys)

- from Maeniana by the posterior wings having the anal area well developed (anal area of posterior wings reduced in Maeniana) and showing a characteristic sexual dimorphism (no sexual dimorphism in the posterior wings in Maeniana)

- from Nirus by the frons being slightly convex (concave in Nirus), the pygofer with the posterior margin strongly projecting posteriorly at dorsal $2 / 3$ (not projecting in Nirus) and the gonostyli being separated and with an elongate basodorsal process (gonostyli fused and with a short basodorsal process in Nirus)

- from Olonia by the pygofer having the posterior margin with an elongate laterodorsal process projecting posteriorly (posterior margin only strongly sinuate in Olonia), the gonostyli separated (fused along about $1 / 3$ of their length in Olonia) and the gonostyli having an elongate basodorsal process bearing a spoon-shaped process apically (spoon-shaped process attached to the lateral process of the laterodorsal part of the gonostylus, which bears a spine or hook, in Olonia)

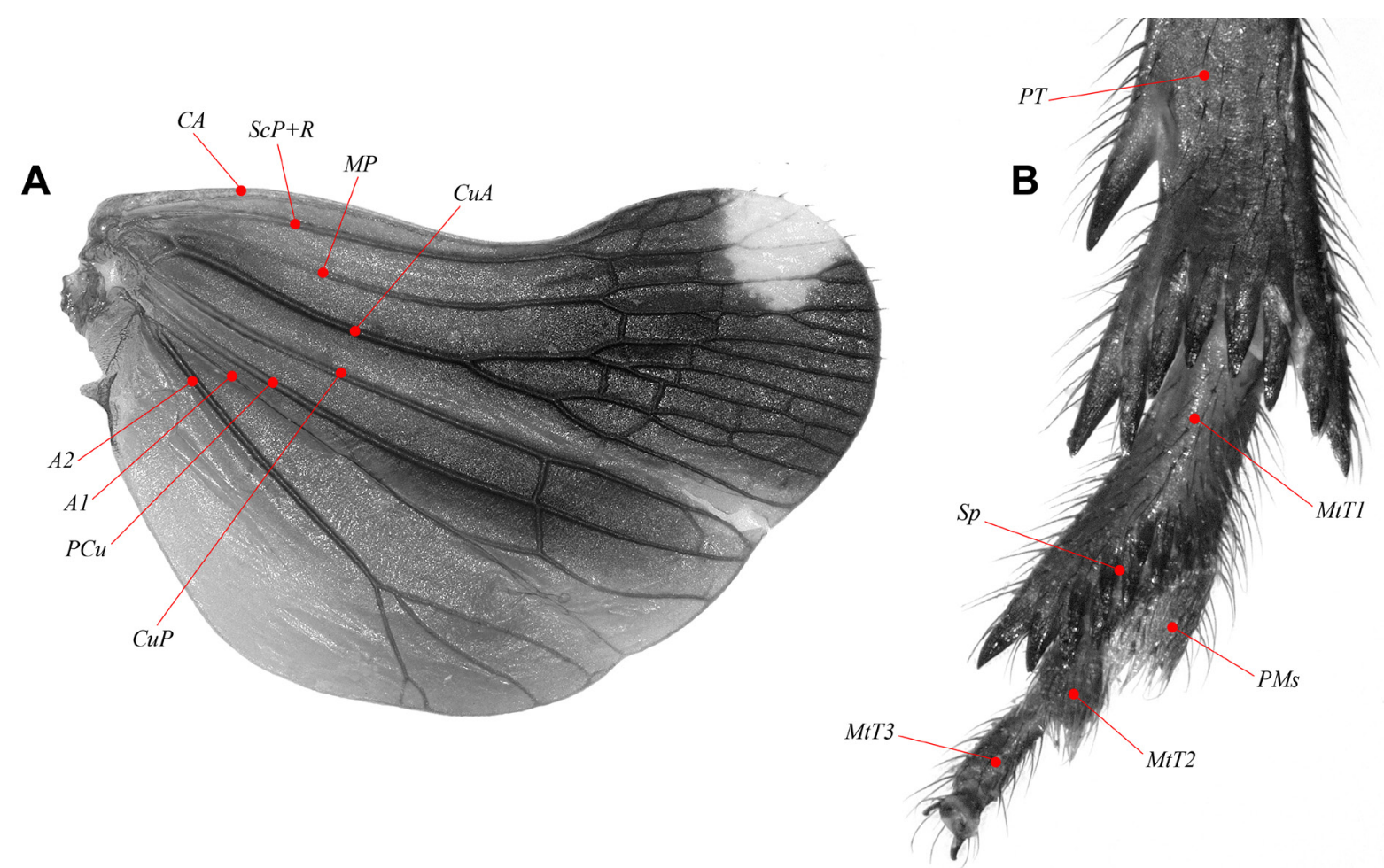

Fig. 50. Stalobrachys gen. nov. A. Right posterior wing, venation. B. Right posterior leg, distal portion, ventral view. Abbreviations: $A 1=$ first anal vein; $A 2=$ second anal vein; $C A=$ costa anterior; $C u A=$ cubitus anterior; $C u P=$ cubitus posterior; $M P=$ media posterior; $M t T 1=$ first metatarsomere; $M t T 2=$ second metatarsomere; $M t T 3=$ third metatarsomere; $P C u=$ postcubitus; $P M s=$ pad of microsetae; $P T=$ posterior tibia; $S c P+R=$ subcosta posterior + radius; $S p=$ spines. 
The genus Loisobrachys Constant, 2008 is known from a single female and was placed by Constant (2008b) close to Hackerobrachys. Hence, the males of that genus potentially share having gonostyli with a spoon-shaped process. However, Stalobrachys gen. nov. can easily be separated from Loisobrachys by its slightly convex frons (frons strongly convex in Loisobrachys) and by the posterior wings having white markings (uniformly brown in Loisobrachys).

\section{Etymology}

The name of this genus is formed from 'Stal' in memory of the great contribution of the late Swedish entomologist Dr Carl Stål (1833-1878) to the study of Hemiptera, and brachys (Greek) = 'short', which is a common ending of generic names in Eurybrachidae. Gender feminine.

\section{Description}

Colouration. Head, pro- and mesonotum, and tegmina brown, from pale brown to nearly black, usually variegated with darker and paler. Tegmina with yellowish marking in middle of clavus on vein A1; triangular white marking along costal magin on nodal line; smaller white marking at apicosutural angle. Posterior wings black-brown, darker from base to distal part; with white subtriangular marking at apicocostal angle in males and with apex largely white in females. Pro- and mesofemora and proand mesotibiae with 2 paler rings; metafemora reddish, turning to brown apically; metatibiae brown. Abdomen and ventral face of thorax bright red; genital segments brown with ventral part of gonostyli white in males; abdominal segment VII white in females.

HEAD. As broad as thorax; vertex 3.4-3.9 times as broad as long, concave, with all margins slightly carinate; anterior and posterior margins rounded, parallel; frons about 2.1 times as broad as long, slightly convex, slightly wrinkled to rugulose, with peridiscal carina slightly marked; upper margin of frons straight in normal view; clypeus slightly surpassing anterior trochanters, elongate, with median carina towards apex; labium reaching hind coxae, with apical segment longer than broad, acuminate, shorter and more slender than penultimate segment; no infra-ocular spines on genae; ocelli absent; antennae elongate, very slightly surpassing eye and visible from above; scape about as long as broad, pedicel elongate, barrel-shaped.

Thorax. About 1.55 times as broad as combined length of pro- and mesonotum; pronotum about half as long as mesonotum; pronotum with disc weakly wrinkled, smooth carina parallel to anterior margin and 2 slightly impressed points on disc; mesonotum with disc weakly wrinkled, median and peridiscal carinae slightly marked.

TEGmina. Slightly convex; curving down at nodal line and with apex slightly curved upwards; elongate, about 2.15-2.5 times as long as broad; costal margin slightly sinuate; apical margin obliquely rounded; sutural margin slightly oblique after clavus. Venation: veins ScP+RA and RP separated close to base;
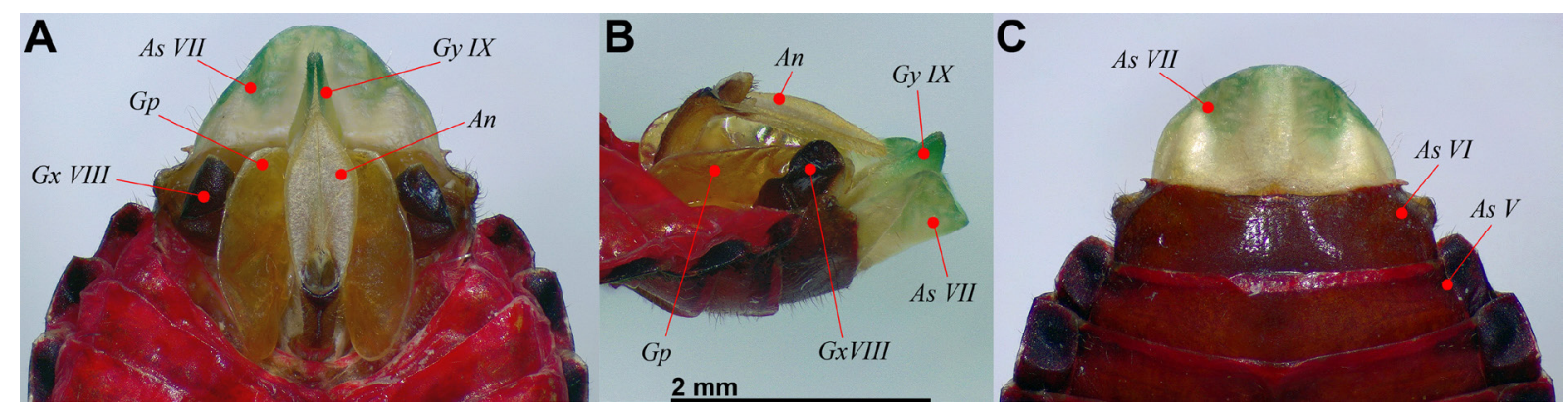

Fig. 51. Stalobrachys gen. nov., female genitalia. A. Dorsal view. B. Left lateral view. C. Ventral view. Abbreviations: $A n=$ anal tube; $A s V=$ fifth abdominal sternite; $A s V I=$ sixth abdominal sternite; $A s V I I=$ seventh abdominal sternite; $G p=$ gonoplac; $G x$ VIII = gonocoxa VIII; $G y I X=$ gonapophysis IX. 
first fork of MP on basal 1/3; first fork of CuA slightly before apex of clavus; clavus closed; Pcu and A1 fused at $2 / 3$ of clavus length; Pcu $+\mathrm{A} 1$ reaching apical angle of clavus; numerous elongate cells along posterior half of costal margin and along apical margin.

Posterior WINGS (Fig. 50A). Well developed, broader than tegmina, rounded apically; LW/BW = 1.5; anal area well developed; sutural margin very weakly trilobous; not reaching apex of tegmina at rest. All main veins visible from base, forked after nodal line and sometimes forming closed cells; transverse veinlets delimiting elongate cells on apical $1 / 3$; vein A2 multiforked, with 2-4 terminals. Arrangement of secondary veins and veinlets variable between specimens and sometimes between the two wings of the same specimen (Fig. 52A).

Legs. Pro- and mesofemora and -tibiae dorsoventrally flattened, elongate and slender; metatibiae with 3 lateral and 9 apical spines; first metatarsomere ventrally with pad of microsetae at interno-apical angle and group of 9 spines distributed more or less in two rows (Fig. 50B). Metatibiotarsal formula: (3) 9/4/0.

Male Genitalia. Pygofer rather short, higher than long and with basal margin sinuate in lateral view; in lateral view, dorsal portion narrower than ventral portion, and strong posterior projection at half heigth; aedeagus attached to apex of posterior process. Anal tube dorsoventrally flattened, elongate; epiproct at basal $1 / 3$. Gonostyli separated, large, mostly dorsoventally flattened, and with an elongate basidorsal process directed dorsally and bearing spoon-shaped process apically. Aedeagus simple; phallobase with dorsal process elongate, projecting posteriorly and with apical part incurving, and ventral part elongate and dorsoventrally flattened; phallus membranous, dorsoventrally flattened and notched apically.

Female terminalia (Fig. 51). Abdominal segment VI strongly narrowing apically, with posterior margin straight in ventral view and with a small posterolateral process projecting laterally (Fig. 51C); anal tube elongate and narrow, strongly curved posteroventrally before anal opening, $\mathrm{v}$-shaped in cross section beyond anus, lanceolate in dorsal view (Fig. 51A-B); gonoplacs unilobed, projecting dorsolaterad, longer than high, not surpassing anal tube (Fig. 51A-B); gonapophysis IX large, elongate, apically rounded and curved dorsad (Fig. 51A-B); gonocoxae VIII looking like reniform inflated pouch (Fig. 51A-B); gonapophysis VIII dorsoventrally flattened and fused together, and with sternite VII in a large semicircular lobe transversely undulate and apically rounded (Fig. 51A-C).

SeXUAL DIMORPHISM. Females slightly larger than males. Colour dimorphism also affecting the colour pattern of posterior wings: males with a white spot at basicostal angle, females with apical margin largely bordered with white.

SizE. $\bigcirc^{\lambda}: 8.8 \mathrm{~mm}$; + : $10.0 \mathrm{~mm}$.

\section{Distribution and biology}

Australia: northern Queensland (Fig. 3). Biology unknown.

\section{Species included (1)}

S. alboapicata (Jacobi, 1928) gen. et comb. nov. (N Queensland)

Stalobrachys alboapicata (Jacobi, 1928) gen. et comb. nov.

Figs 3, 50-54

Olonia alboapicata Jacobi, 1928: 5 (described).

Olonia alboapicata - Metcalf 1956: 65 (catalogued).

\section{Diagnosis}

As for genus. 


\section{Etymology}

The species is epithet is formed from albus (adjective, Latin) = 'white' and 'apex'. It refers to the white apical patch of the posterior wing.

\section{Material examined}

\section{Holotype}

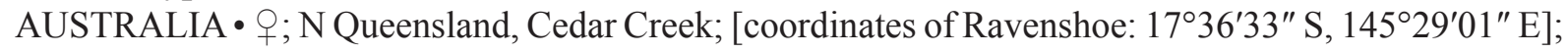
"Queensl. Mjöberg”, “Cedar creek", “Olonia alboapicata Jac., A. Jacobi determ.”, “Typus”, "Typus”; NHRS (Fig. 52).

\section{Notes}

Jacobi (1928) erroneously stated that the type specimen is a male. He was apparently prone to confusing males and females of Eurybrachidae, as he made the same mistake for the types of Elthenus modestus Jacobi, 1928 and Olonia nigroapicata Jacobi, 1928 (Constant 2005b, 2006b, respectively).

Cedar Creek was a Jirrbal aboriginal camp located at the southern edge of Ravenshoe (North Queensland). It covers 38 ha of grassland and woodland on a basalt plateau bordered by North Cedar Creek, South Cedar Creek and the Millstream River in the west. It represented an Eucalyptus "pocket" at the edge of the rainforest. Mjöberg and his staff sampled the location 29 Mar.-17 Apr. 1913 (Ferrier 2006, 2015).

\section{Additional material}

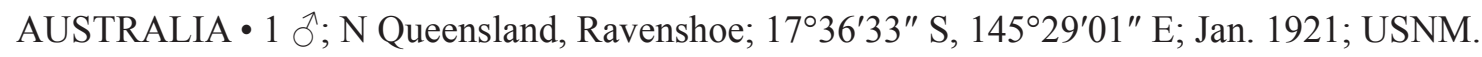

\section{Description}

Measurements AND Ratios. LT: $\widehat{\partial}(\mathrm{n}=1): 8.8 \mathrm{~mm} ;$ q $(\mathrm{n}=1): 10.0 \mathrm{~mm} ; \mathrm{BV} / \mathrm{LV}=3.9 ; \mathrm{BF} / \mathrm{LF}=2.0$; $\mathrm{LP}+\mathrm{LM} / \mathrm{BT}=0.61 ; \mathrm{Ltg} / \mathrm{BTg}=2.17 ; \mathrm{LW} / \mathrm{BW}=1.6$.

\section{Male}

HEAD (Fig. 53A-D). Vertex concave, with anterior and posterior margins parallel, curved, slightly wrinkled longitudinally; yellowish brown with an impression marked with darker colour at each side of disc. Frons dark brown variegated with blackish. Clypeus elongate, coloured as frons. Genae brown. Labium brown, reaching metacoxae. Antennae dark brown; scape short, ring-shaped; pedicel subcylindrical, slightly narrowing towards apex.

Thorax (Fig. 53A-C). Pronotum yellowish brown, dark brown at lateral angles; slightly wrinkled; median carina obsolete and 2 small, impressed points on disc. Lateral fields of prothorax dark brown. Mesonotum dark brown, transversely wrinkled; small yellowish spot at apex of scutellum; median and peridiscal carinae weakly marked. Red ventrally. Tegulae brown.

Tegmina (Fig. 53A, C). Brown, darker on clavus and apicocostal half of membrane, irregularly marked with small yellowish spots; one larger pale yellowish marking on vein A1 at midlength of clavus; triangular white marking on costal margin after nodal line; white marking at apicosutural angle. Costal and sutural margins subparallel until nodal line, then slightly converging; costal margin slightly sinuate; apical margin obliquely rounded.

PosterioR wings (Fig. 53E). Dark brown, paler on anal area and becoming darker, nearly black on about distal third; elongate, transverse, subtriangular white marking at apicocostal angle, extending on 4 cells. Margin of anal area slightly sinuate; sutural margin with 2 clefts, cubital one not marked.

Legs (Fig. 53A-D). Pro- and mesocoxae reddish brown. Pro- and mesofemora dark brown with reddish and yellowish spots marking obsolete rings. Pro- and mesotibiae dark brown with yellowish markings on 2 obsolete rings. Pro- and mesotarsi dark brown, with basal half of third tarsomere reddish. Metacoxae 
reddish; metafemora reddish with apex brown. Metatibiae brown, with 3 lateral spines yellowish basally and black distally, and 9 apical black-brown spines. Metatarsi reddish brown, with first tarsomere darker distally and with a ventral group of 9 black spines in two irregular rows.

AвDOMEN. Bright red with genital segments yellowish white.

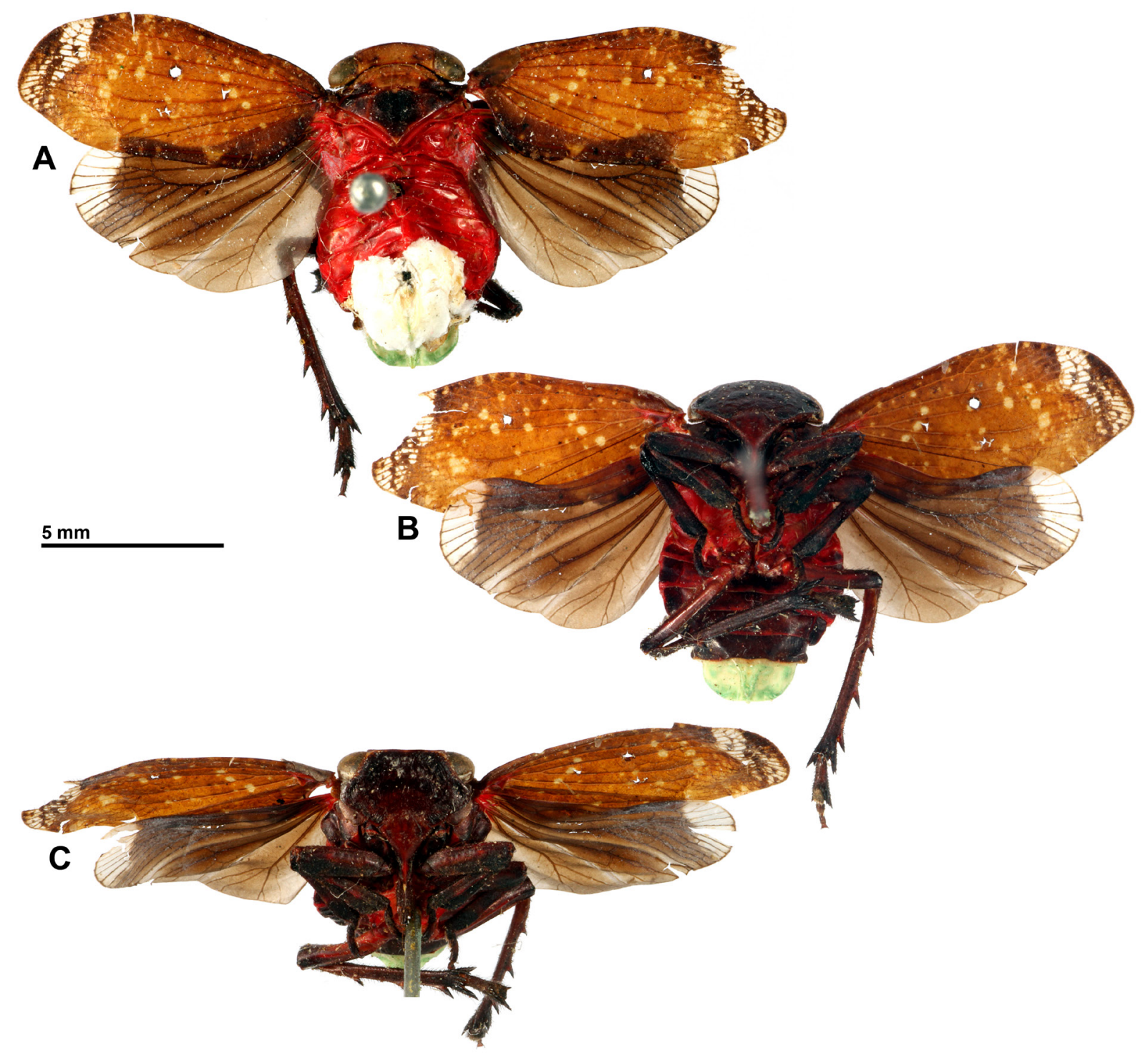

D

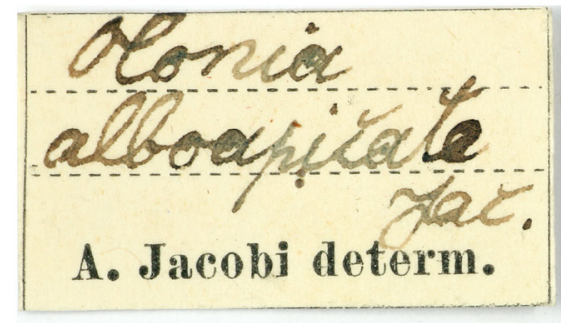

Cedar Queensl. creek Mjöberg

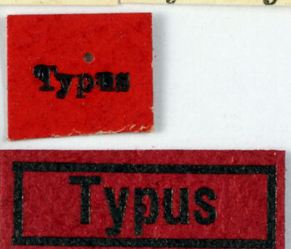

Fig. 52. Stalobrachys alboapicata gen. et comb. nov. (Jacobi, 1928), holotype, ․ . A. Habitus, dorsal view. B. Habitus, ventral view. C. Habitus, normal view of frons. D. Labels. 
Male genitalia (Fig. 54). Pygofer, anal tube and gonostyli whitish. Pygofer higher than long, with basal margin sinuate in lateral view; in lateral view, dorsal $2 / 5$ very narrow and ventral $2 / 5$ more than two times as broad as dorsal portion; strong posterior projection at half heigth, about twice as long as ventral portion (Fig. 54A, C). Anal tube dorsoventrally flattened, elongate, rounded apically in dorsal view and with posteromedian portion slightly depressed; epiproct at basal 1/3 (Fig. 54A-B). Gonostyli separated, large, mostly dorsoventally flattened, with elongate basidorsal process directed dorsally and bearing spoon-shaped process apically. Aedeagus simple; phallobase with dorsal process elongate, projecting
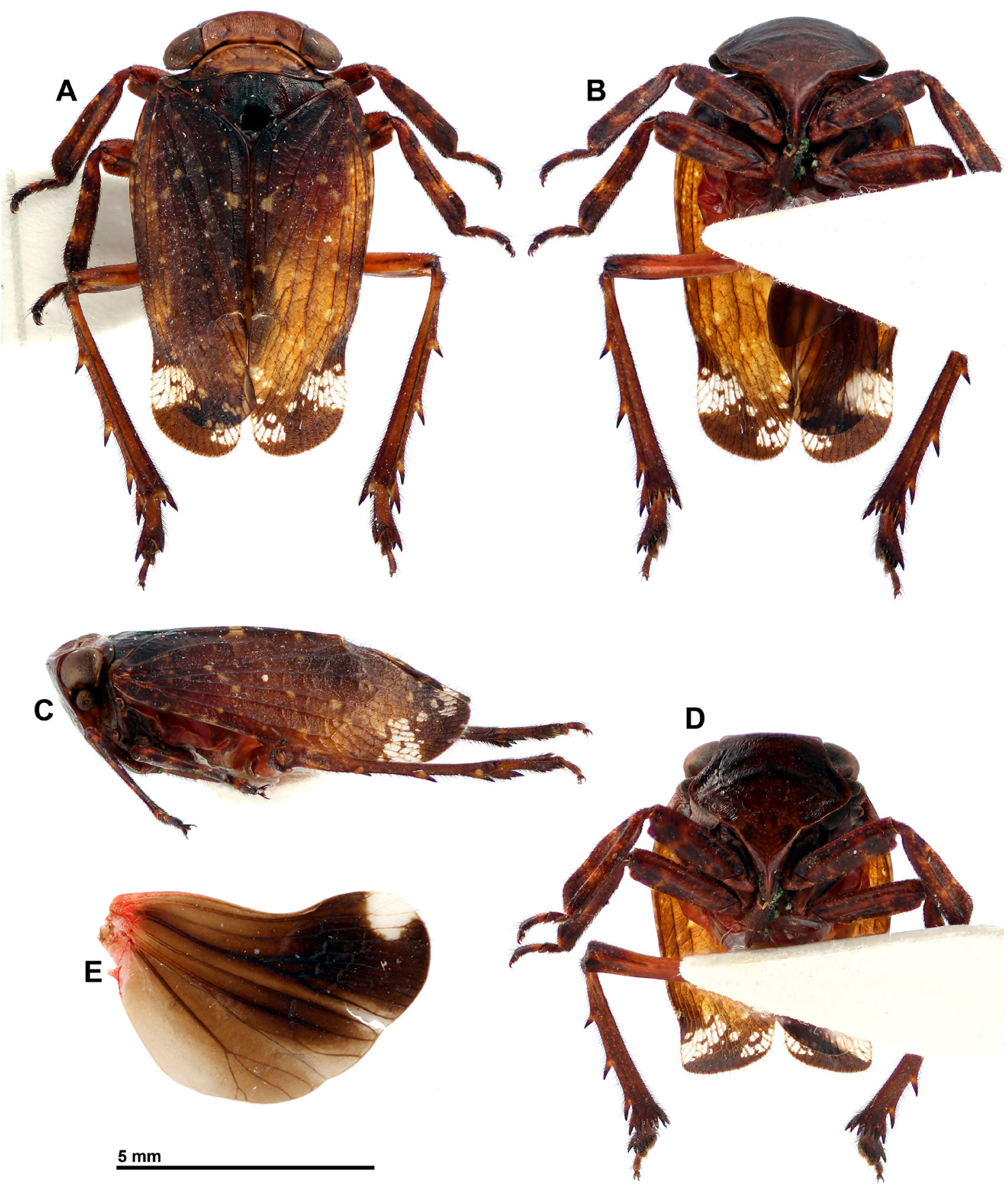

Fig. 53. Stalobrachys alboapicata gen. et comb. nov. (Jacobi, 1928), §. A. Habitus, dorsal view. B. Habitus, ventral view. C. Habitus, lateral view. D. Habitus, normal view of frons. E. Posterior wing. 


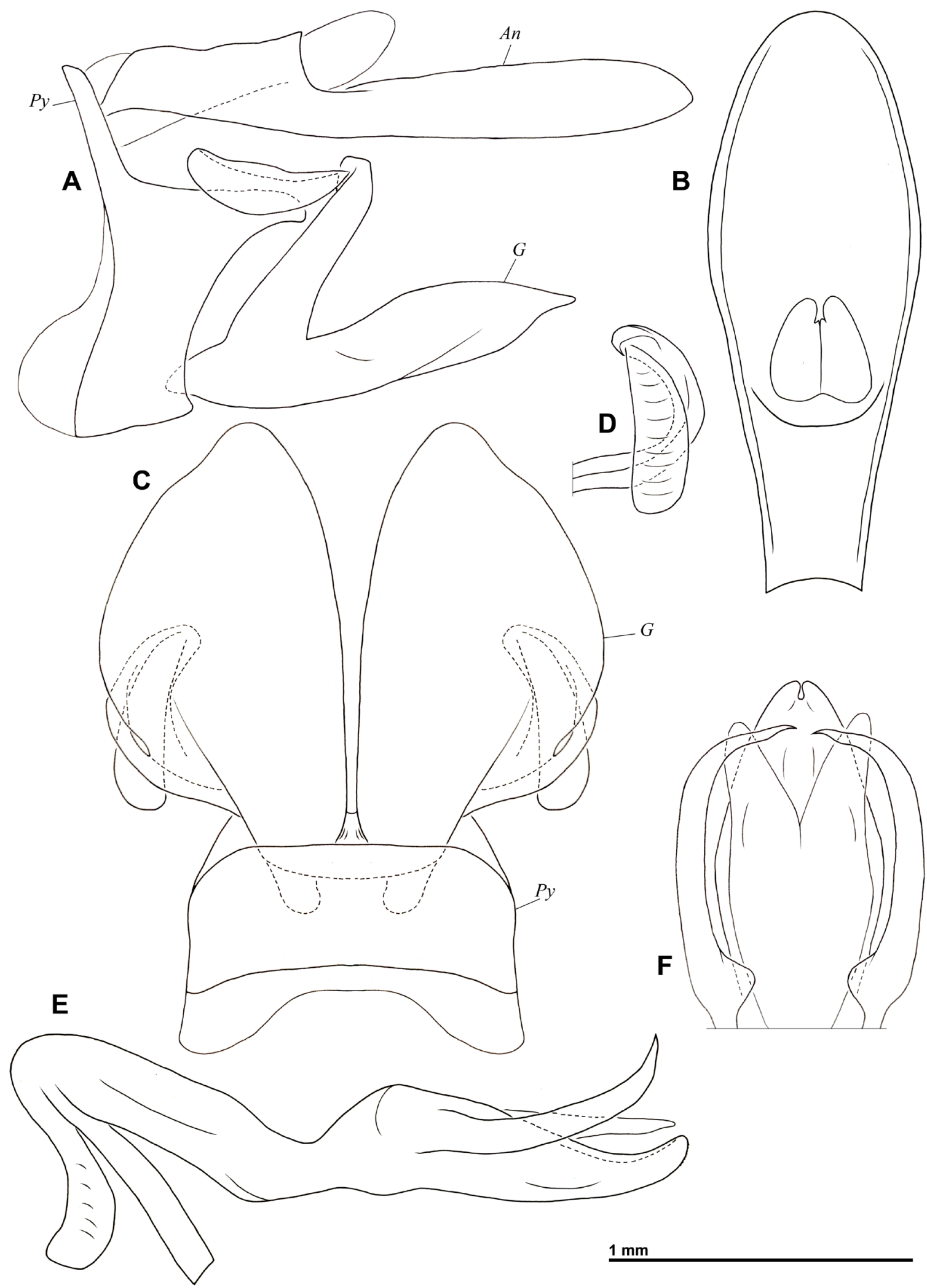

Fig. 54. Stalobrachys alboapicata gen. et comb. nov. (Jacobi, 1928), $\widehat{\partial}$, genitalia. A. Pygofer, anal tube and gonostyli, left lateral view. B. Anal tube, dorsal view. C. Pygofer and gonostyli, ventral view. D. Laterodorsal part of left gonostylus, dorsal view. E. Aedeagus, left lateral view. F. Aedeagus, dorsal view. Abbreviations: $A n=$ anal tube; $G=$ gonostyli; $P y=$ pygofer. 
posteriorly and with apical part incurving, and ventral part elongate and dorsoventrally flattened and notched apically; phallus membranous, dorsoventrally flattened and bifid on distal $1 / 3$.

\section{Female}

Similar to male, but with distal cells of posterior wings white instead of having a white spot at the apicosutural angle (Fig. 52).

\section{Distribution and biology}

This species is recorded only from a small area around Ravenshoe, at the limit between the Queensland Tropical Rainforests and the Einasleigh Upland Savanna bioregions (Fig. 3). The specimens were found in January and April, one of them in a habitat of mixed grassland and woodland on a basalt plateau described as a Eucalyptus patch at the edge of the rainforest (Ferrier 2006, 2015). However, host plants remain undocumented.

Genus Maeniana Metcalf, 1952

Maenia Jacobi, 1928: 6 (nec Maenia Dalton, 1877) (type species: Maenia hirsuta Jacobi, 1928 by original designation).

Maeniana Metcalf, 1952: 228 (nom. nov. pro Maenia Jacobi, 1928 nec Maenia Dalton, 1877).

Maeniana - Metcalf 1956: 67 (catalogued).

\section{Remarks}

The most relevant diagnostic characters to recognize the genus Maeniana are these of the male genitalia (based on the male holotype of M. hirsuta (Jacobi, 1928)):

(1) posterior margin of the pygofer with elongate laterodorsal process projecting posteriorly

(2) gonostyli not or very shortly fused basally

(3) laterodorsal part of the gonostyli elongate and laminate, without spine or hook, and bearing spoonshaped process apically

Maeniana apicalis (Walker, 1851) comb. nov.

Fig. 55

Eurybrachys apicalis Walker, 1851: 393 (described).

Olonia apicalis - Stål 1862: 488 (transferred to Olonia in key to genera of Eurybrachidae). — Atkinson 1886: 13 (English translation of Stål's key). — Kirkaldy 1906: 445 (listed).

non Olonia apicalis - Lallemand 1935 (listed from Fergusson River, Katherine, Northern Territory, Australia (erroneous identification)).

\section{Material examined}

\section{Holotype}

AUSTRALIA - ; W Australia, NW coast; "N. Holl., N.W. Coast /on the reverse/ 44, 14", "Type", "Eurybrachys apicalis,", "Re-pinned on stainless"; BMNH.

\section{Remarks}

This species is known from a single female, but closely related species were examined in the course of this study and their male genitalia show that they belong to the genus Maeniana, a view supported by a comparison with the male genitalia of the type species, Maeniana hirsuta (Jacobi, 1928) (Constant, unpublished data). 


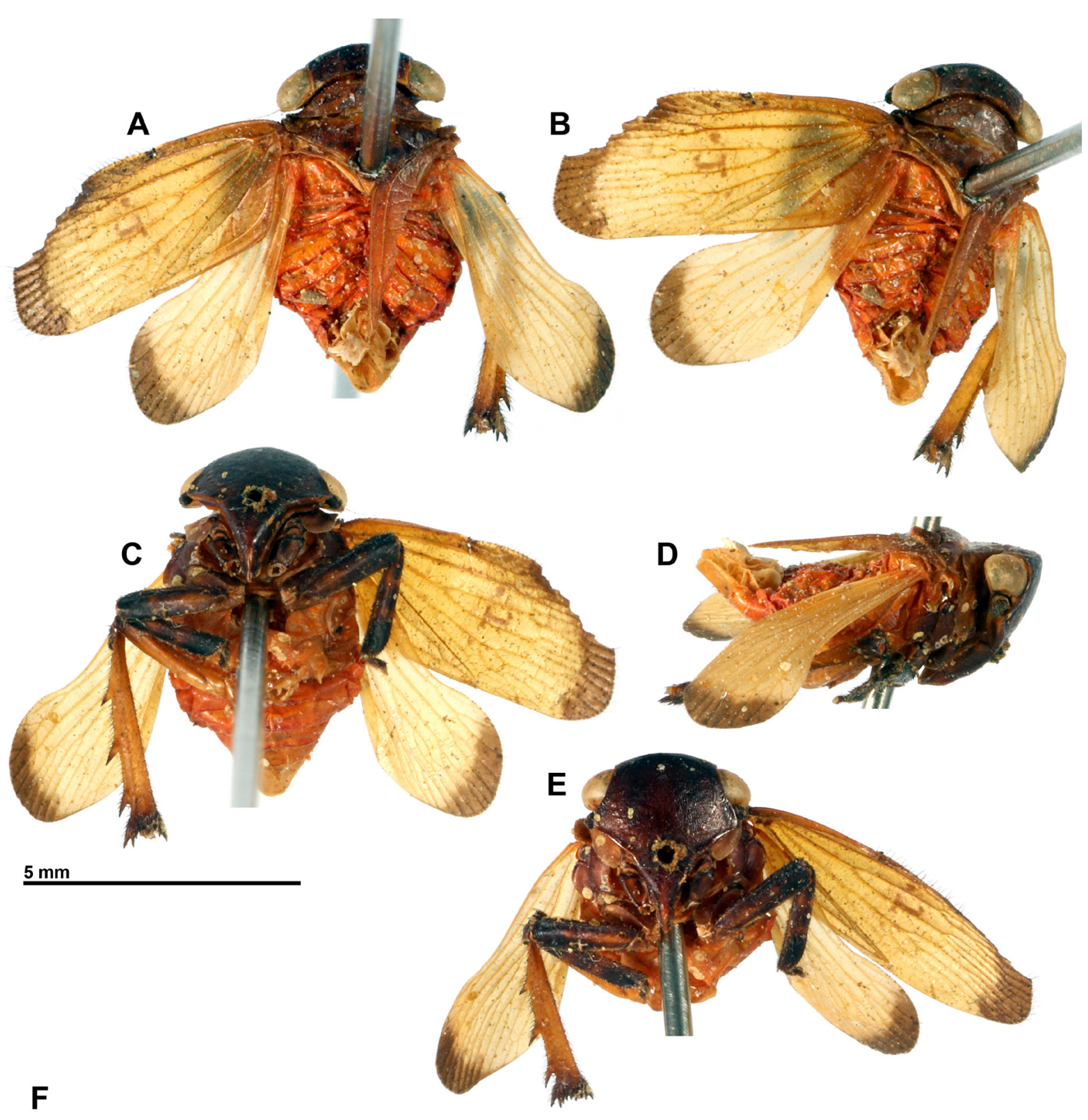

$\mathbf{F}$
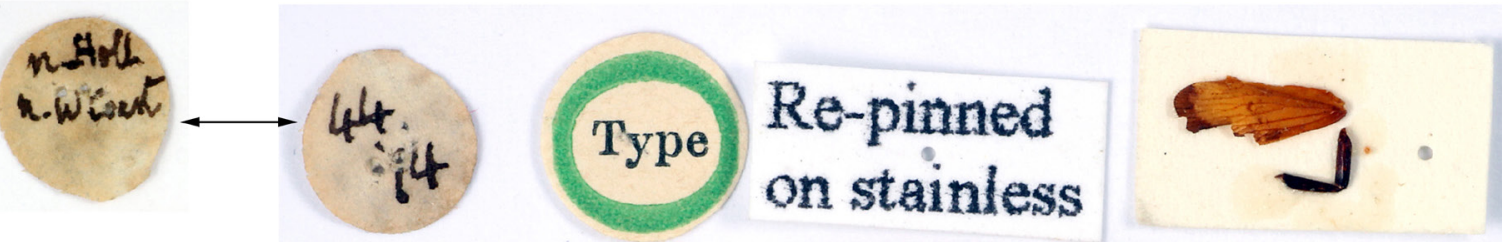

\section{EURYBRACHYS ARICALIS,}

Fig. 55. Maeniana apicalis (Walker, 1851), holotype,, . A. Habitus, dorsal view. B. Habitus, laterodorsal view. C. Habitus, ventral view. D. Habitus, lateral view. E. Habitus, normal view of frons. F. Labels (with leg and right tegmen). 
Genus Platybrachys Stål, 1859

Platybrachys Stål, 1859: 280 (type species: Platybrachys lanata (Stål, 1854) by monotypy).

Platybrachys - Stål 1861: 210 (keyed); 1862: 488 (keyed, list of included species); 1863: 248 (compared with Lyncilia Stål, 1863), 249 (key to species). — Atkinson 1886: 13 (keyed). — Karsch 1890: 60 (compared with Mesonitys Karsch, 1890); 1895: 215 (compared with Aspidonitys Karsch, 1895). - Melichar 1903: 67 (comparative note). - Distant 1906: 206 (type species = Platybrachys decemmacula (Walker, 1851) (error)). — Kirkaldy 1906: 443 (keyed, notes); 1907: 6 (ecology: genus of Eucalyptus forests), 105 (problem of generic definition). - Schmidt 1908: 243 (listed). - Hacker 1924: 37 (natural history), 40 (compared with Olonia Stål, 1862). — Evans 1938: 4 (morphology). — Metcalf 1947: 163 (zoogeography); 1956: 67 (catalogued). — Fennah 1964: 159 (keyed), 160 (senior synonym of Lyncilia Stål, 1863 (erroneous)). - Constant 2006a: 47 (notes); 2006b: 31 (compared with Olonia); 2008a: 41 (compared with Chewobrachys Constant, 2008).

Platybrachys ornata (Lallemand, 1928) comb. nov.

Fig. 56

Olonia ornata Lallemand, 1928: 393 (described).

Olonia ornata-Metcalf 1956: 65 (catalogued).

\section{Material examined}

Holotype

AUSTRALIA • $\odot$; Northern Territory, Hermansburg; "Hermansburg, N.T., S. Australia, H.J. Hillier. 1907-233.”, “Type”, “Olonia ornata Lallemand, Type, dét. V. Lallemand 19”, “10”; BMNH.

\section{Remarks}

The species is known from a single female and the key to the genera proposed by Fennah (1964) leads to the genus Platybrachys Stål, 1859. It is quite similar to P. leucostigma (Walker, 1851) (illustrations of the latter species available in Hacker 1924: fig. 14) by showing an apical white border on the posterior wings and numerous elongate cells in the costal area. The species is here transferred to Platybrachys, although it is obvious that a complete revision of the genus will be necessary (Constant 2008a).

\section{Discussion}

\section{Taxonomic issues}

I recently described two genera (Constant 2006b) to include species previously placed in Olonia:

(1) Hackerobrachys Constant, 2006 to accommodate O. viridiventris Stål, 1863, and

(2) Fletcherobrachys Constant, 2006 to accommodate Platybrachys stillata Bergroth, 1907, under which I synonymized $O$. nigroapicata Jacobi, 1928

The study of the type specimens and available material from many museums raised the issue of the inconsistency of the genus Olonia, as already partly treated in Constant (2006b). The study of the male genitalia revealed that the species Olonia alboapicata Jacobi, 1928 does not belong in Olonia and cannot be placed in one of the existing genera. The new genus Stalobrachys gen. nov. is hence necessary to accommodate this species.

The species Olonia ornata Lallemand, 1928, described from a female specimen from Hermannsburg (erroneously spelled "Hermansburg" by Lallemand 1928) in the Northern Territory near Alice Springs, 
does not belong in Olonia and is transferred to Platybrachys. Olonia apicalis, described from the northwestern coast of Australia by Walker (1851), does not belong in Olonia either and is transferred to Maeniana Metcalf, 1952.

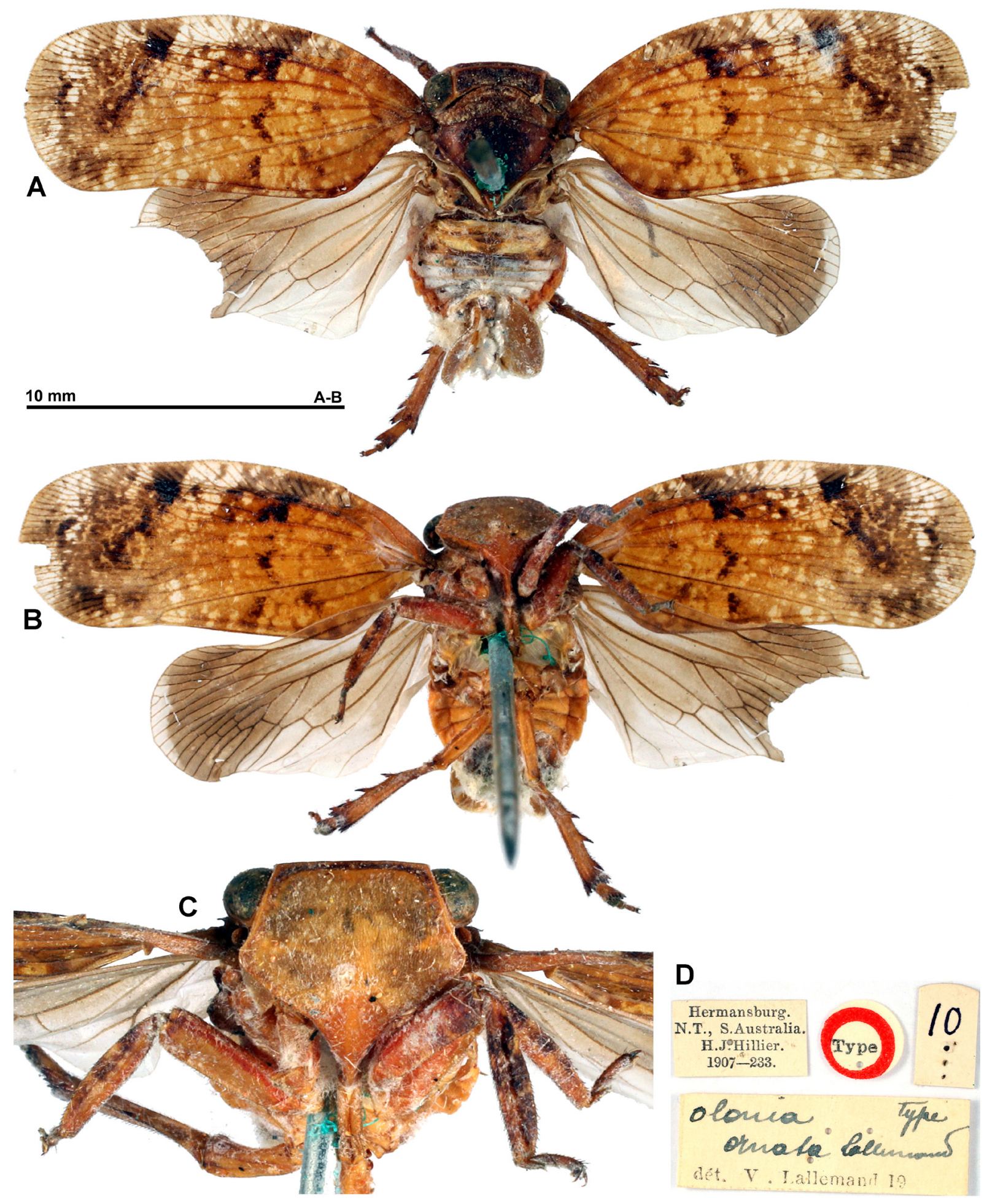

Fig. 56. Platybrachys ornata (Lallemand, 1928) comb. nov., holotype, +. A. Habitus, dorsal view. B. Habitus, ventral view. C. Habitus, normal view of frons. D. Labels. 
The review of the specimens reported by Jacobi (1928) as belonging to Olonia revealed the following errors:

(1) the specimens identified as Olonia rubicunda (Walker, 1851) from Kimberley District (Western Australia instead of Northern Territory, as erroneously stated by Jacobi) represent a new species, the generic attribution of which will be treated in another paper (Constant, unpublished data)

(2) the specimens mentioned under Olonia transversa (Walker, 1858) were misidentified and the synonymy of Olonia picea Kirkaldy, 1906 is erroneous (Constant 2005b)

(3) Olonia nigroapicata Jacobi, 1928 is actually a junior synonym of Fletcherobrachys stillata (Bergroth, 1907) (Constant 2006b)

\section{Male genitalia}

The genus Olonia is well characterized by the shape of the male genitalia, with a reduced aedeagus and very specialized, strongly sclerotized gonostyli. The male genitalia also offer very relevant characters for species separation. Although externally very similar, the genus Stalobrachys gen. nov. can be separated from Olonia at first glance if the male genitalia are considered. However, both genera show a peculiar spoon-shaped process on the gonostyli, a character shared also with the genera Chewobrachys Constant, 2008, Fletcherobrachys Constant, 2006, Hackerobrachys Constant, 2006, Maeniana Metcalf, 1952 and Nirus Jacobi, 1928, and probably also Loisobrachys Constant, 2008 although the latter is known only from a single female. All these genera are from Australia and it seems that the "spoonshaped process character" allows the separation of a consistent group among the Eurybrachidae from Australia, the status of which will need further study. More than $70 \%$ of the Australian eurybrachids remain undescribed, both at specific and generic levels (Constant, unpublished data), and molecular data would provide a great help for the assessment of suprageneric relationships. The role of the spoonshaped process remains unknown and requires the observation of living specimens.

\section{Biological data}

The present work also provides a series of new host plant data, which clearly shows that species of Olonia are polyphagous, as opposed to the other Australian genera for which host plants have been recorded, e.g., Chewobrachys Constant, 2008, Gelastopsis Kirkaldy, 1906 and Hackerobrachys Constant, 2006 being recorded only on Acacia spp. (Fabaceae), and Platybrachys Stål, 1859 recorded only on Eucalyptus spp. (Myrtaceae) (Hacker 1924; Constant 2006b, 2008a; Bourgoin 2018). The list of host plants of Olonia spp. contains species of the family Myrtaceae: Melaleuca quinquenervia (Cav.) S.T.Blake, Eucalyptus sp. and Corymbia tesselaris K.D.Hill \& L.A.S.Johnson; Bursaceae: Canarium australianum F.Muell.; Vitaceae: Vitis vinifera L.; Urticaceae: Pipturus argentaeus Wedd.; Solanaceae: Solanum tubiferum L.; Convolvulaceae: Ipomoea pes-caprae (L.) R.Br. More host plants will likely be recorded if more field research is conducted. On the other hand, the host plants of Stalobrachys gen. nov. remain undocumented. From the available data, the species of Olonia seem to be present as adults all year round, but this requires confirmation from additional field work. The habitat requirements of the different species need to be defined from field observations rather than by extrapolation from the general habitat represented in each bioregion, e.g., O. marginata is present in the Queensland tropical rainforests bioregion, but was recorded from open coastal areas and vineyards rather than from the rainforest. It is also interesting to note that the genus seems to be restricted to the eastern part of Queensland, extending to the Great Dividing Range to the west, and mountains might have played a role in the speciation within the genus; however, this hypothesis requires a much more complete knowledge of the actual distribution of the species before any conclusion can be proposed.

\section{Acknowledgements}

For the loan of the material under their care, I thank Dr Dave Britton (AMS), Mr Tom A. Weir (ANIC), Dr Murray J. Fletcher (ASCU), Miss Theresa M. Howard, Mr Mick Webb and Mr Max Barclay (BMNH), 
Mr Jim Boone (BPBM), Dr Norman Penny (CAS), Dr Christopher H. Dietrich (INHS), Prof. Dr. Thierry Bourgoin (MNHN), Dr Ken Walker (MVMA), Mrs Gunvi Lindberg (NHRS), Mr J.F. Donaldson (QDPI), Dr Christine Lambkin (QM), the late Mr Ross Storey (QPIM), Dr Jan van Tol and Mrs Yvonne van Nierop (RMNH), Ms Jan Forrest (SAM), Mr Edward G. Riley (TAMU), Dr Stuart McKamey (USNM), Dr Jürgen Deckert (ZMHB) and Dr Jacek Szwedo and Dr Adam Stroinski (ZMPA). I also thank Mrs Valry Ryland (Magnetic Island, QLD) for providing photographs, observations and specimens and Dr Christine Lambkin and Mrs Susan Wright for arranging the transfer of the latter; Dr Anne Hoggett (Lizard Island Research Station, AMS) for providing photographs, observations and specimens; Mr Graeme Cocks (Townsville, QLD) for providing specimens; Mr Gary W. Wilson (Australian Tropical Herbarium, Cairns) for the identification of Canarium australianum from photographs; Mr Harald Bruckner and Dr Herbert Zettel (NHMW) for the photographs of the specimen from Signoret's collection and Dr M.J. Fletcher for his help with identification; Mr Pol Limbourg, Mr Joachim Bresseel and Dr Patrick Grootaert (RBINS) and Prof. Dr T. Bourgoin for their support; and Miss Mado Berthet (RBINS) for her help in improving the nymph plate. This study benefitted from funds from the European Union for visits to the collections of BMNH (Synthesys Project - Grant GB-TAF-1642) and NHRS (Synthesys Project - Grant SE-TAF-527).

\section{References}

Atkinson E.T. 1886. Notes on Indian Rhynchota. No. 5. Journal of the Asiatic Society of Bengal 55: 12-83. Available from https://www.biodiversitylibrary.org/page/35545361 [accessed 23 Sep. 2018].

Banks J. 1771. The Endeavour Journal of Sir Joseph Banks. Available from http://gutenberg.net.au/ebooks05/0501141h.html\#jul1770 [accessed 6 Sep. 2017].

Bourgoin T. 1993. Female genitalia in Hemiptera Fulgoromorpha, morphological and phylogenetic data. Annales de la Société entomologique de France 29: 225-244.

Bourgoin T. 2018. FLOW (Fulgoromorpha Lists On the Web): a World Knowledge Base Dedicated to Fulgoromorpha. Ver. 8, updated. Available from http://hemiptera-databases.org/flow/ [accessed 18 Jun. 2018].

Bourgoin T., Wang R.R., Asche M., Hoch H, Soulier-Perkins A., Stroinski A., Yap S. \& Szwedo J. 2015. From micropterism to hyperpterism: recognition strategy and standardized homology-driven terminology of the fore wing venation patterns in planthoppers (Hemiptera: Fulgoromorpha). Zoomorphology 134 (1): 63-77. https://doi.org/10.1007/s00435-014-0243-6

Carayon J. 1969. Emploi du noir chlorazol en anatomie microscopique des insectes. Annales de la Société entomologique de France 5: 179-193.

Constant J. 2004. Révision des Eurybrachidae (I). Le genre Amychodes Karsch, 1895 (Homoptera: Fulgoromorpha: Eurybrachidae). Bulletin de l'Institut royal des Sciences naturelles de Belgique 74: $11-28$.

Constant J. 2005a. Revision of the Eurybrachidae (III). The Afrotropical genus Metoponitys Karsch, 1890 (Hemiptera: Fulgoromorpha: Eurybrachidae). Bulletin de l'Institut royal des Sciences naturelles de Belgique 75: 41-56.

Constant J. 2005b. Revision of the Eurybrachidae (IV). The Australian genus Gelastopsis Kirkaldy, 1906 (Hemiptera: Fulgoromorpha: Eurybrachidae). Bulletin de l'Institut royal des Sciences naturelles de Belgique 75: 57-69.

Constant J. 2006a. Revision of the Eurybrachidae (V). Description of the new Australian genus Kirkaldybrachys Constant (Hemiptera: Fulgoromorpha: Eurybrachidae). Bulletin de la Société royale belge d'Entomologie 142: 47-54. 
Constant J. 2006b. Revision of the Eurybrachidae (VII). The Australian genera Hackerobrachys and Fletcherobrachys (Hemiptera: Fulgoromorpha: Eurybrachidae). Bulletin de l'Institut royal des Sciences naturelles de Belgique 76: 31-40.

Constant J. 2008a. Revision of the Eurybrachidae (XIII). The new Australian genus Chewobrachys (Hemiptera: Fulgoromorpha). Zootaxa 1898: 41-54.

Constant J. 2008b. Revision of the Eurybrachidae (XIV). The new Australian genus Loisobrachys (Hemiptera: Fulgoromorpha). Annales Zoologici 58 (4): 755-759.

Distant W.L. 1906. Rhynchotal notes xxxix. Annals and Magazine of Natural History, Series 718 : 191-208. https://doi.org/10.1080/00222930608562600

Distant W.L. 1908. On some Australian Homoptera. Synonymical notes. Annales de la Société entomologique de Belgique 52: 97-111. Available from http://biodiversitylibrary.org/page/13193447 [accessed 23 Sep. 2018].

Donovan E. 1805. An Epitome of the Natural History of the Insects of New Holland, New Zealand, New Guinea, Otaheite, and Other Islands in the Indian, Southern, and Pacific Oceans. F.C. \& J. Rivington, London.

Donovan E. 1820. Cicada. In: Rees A. (ed.) The Cyclopaedia; or, Universal Dictionary of Arts, Sciences and Literature 8: 115-121. Available from https://biodiversitylibrary.org/page/38741207 [accessed 23 Sep. 2018].

Evans J.W. 1933. A revision of the Eurymelini (Homoptera, Bythoscopidae). Transactions and Proceedings of the Royal Society of South Australia 57: 73-90.

Available from https://biodiversitylibrary.org/page/41569875 [accessed 23 Sep. 2018].

Evans J.W. 1938. Australian leaf-hoppers (Homoptera, Jassoidea), Part VIII. Papers and Proceedings of the Royal Society of Tasmania 1938: 1-18.

Fabricius J.C. 1775. Ryngota. In: Fabricius J.C. 1775. Systema Entomologiae, Sistens Insectorum Classes, Ordines, Genera, Species, Adiectis Synonymis, Locis, Descriptionibus, Observationibus: 673-689. Kortius, Flensburg and Leipzig. Available from https://biodiversitylibrary.org/page/25552060 [accessed 1 Oct. 2018].

Fabricius J.C. 1781. Species Insectorum Exhibentes eorum Differentias Specificas, Synonyma Auctorum, Loca Natalia, Metamorphosin Adiectis Observationibus, Descriptionibus. Bohnius, Hamburg and Kiel. https://doi.org/10.5962/bhl.title.36509

Fabricius J.C. 1787. Mantissa Insectorum Sistens Species Nuper Detectas Adiectis Synonymis, Observationibus, Descriptionibus, Emendationibus 2. Proft, Havniae [Copenhagen].

https://doi.org/10.5962/bhl.title.36471

Fabricius J.C. 1794. Entomologia Systematica Emendata et Aucta: Secundun Classes, Ordines, Genera, Species, Adjectis Synonimis, Locis, Observationibus, Descriptionibus 4: 1-472. Proft, Havniae [Copenhagen]. http://dx.doi.org/10.5962/bhl.title.36532

Fabricius J.C. 1803. Systema Rhyngotorum Secundum Ordines, Genera, Species, Adiectis Synonymis, Locis, Observationibus, Descriptionibus. Carolus Reichard, Braunschweig. https://doi.org/10.5962/bhl.title.11644

Fennah R.G. 1964. Three new genera of Eurybrachidae (Homoptera: Fulgoroidea) from West Africa and Australia. Proceedings of the Entomological Society of London B 33 (9-10): 157-162.

Ferrier A. 2006. Dr Eric Mjöberg's 1913 scientific exploration of North Queensland's rainforest region. Memoirs of the Queensland Museum, Cultural Heritage Series 4 (1): 1-27. 
Ferrier $\AA$. 2015. Journeys into the rainforest: archaeology of culture change and continuity on the Evelyn Tableland, North Queensland. Terra Australis 43: 1-174.

Germar E.F. 1830. Species cicadarium enumeratae et sub genera distributae. Thon's Entomologisches Archiv 2 (2): 1-57.

Gmelin J.F. 1789. Caroli a Linné. Systema Naturae per Regna tria Naturae: Secundum Classes, Ordines, Genera, Species, cum Characteribus, Differentiis, Synonymis, Locis 1 (4): 1517-2224. Emanuel Beer, Leipzig. https://biodiversitylibrary.org/page/25745483

Goeze J.A.E. 1778. Entomologische Beyträge zu des Ritter Linné zwölften Ausgabe des Natursystems. Vol. 2. Weidmanns Erben und Reich, Leipzig. https://doi.org/10.5962/bhl.title.45974

Hacker H. 1924. Field notes on Platybrachys, \& c. (Homoptera). Memoirs of the Queensland Museum 8: $37-42$.

Ingram G. 1998. Trip Report: Bakers Blue Mountain (NE Queensland, Australia), July 17, 1997. Available from http://www.camacdonald.com/birding/tripreports/BakersMt97.html [accessed 26 Dec. 2015].

Jacobi A. 1928. Results of Dr E. Mjöberg's Swedish Scientific Expeditions to Australia 1910-1913. Rhynchota Homoptera. 1. Fulgoridae und Cercopidae. Arkiv för Zoologi 19A (28): 1-50.

Karsch F.A.F. 1890. Afrikanische Fulgoriden. Berliner Entomologische Zeitschrift 35: 57-70. Available from https://www.biodiversitylibrary.org/page/25049326 [accessed 23 Sep. 2018].

Karsch F.A.F. 1895. Aethiopische Eurybrachiden. Entomologische Nachrichten 21: 209-217. Available from https://www.biodiversitylibrary.org/page/25411449 [accessed 23 Sep. 2018].

Kershaw J.C. \& Muir F. 1922. The genitalia of the auchenorhynchous Homoptera. Annals of the Entomological Society of America 15 (3): 201-211.

Kirkaldy G.W. 1906. Leaf hoppers and their natural enemies. Bulletin of the Experiment Station of the Hawaiian Sugar Planters' Association, Division of Entomology 1 (9): 271-479.

Available from https://biodiversitylibrary.org/page/15499805 [accessed 24 Sep. 2018].

Kirkaldy G.W. 1907. Leaf hoppers supplement (Hemiptera). Bulletin of the Experiment Station of the Hawaiian Sugar Planters' Association, Division of Entomology 3: 1-186.

Available from https://biodiversitylibrary.org/page/15500139 [accessed 24 Sep. 2018].

Lallemand V. 1928. Fulgorides nouveaux provenant de la collection du British Museum. Annals and Magazine of Natural History, Series 101 (2): 241-249. https://doi.org/10.1080/00222932808672768

Lallemand V. 1935. Homoptères des Iles de la Sonde et de l'Australie du Nord. Annales de la Société zoologique suisse et du Muséum d'Histoire naturelle de Genève 42: 661-681.

Melichar L. 1903. Homopteren-Fauna von Ceylon. F.L. Dames, Berlin.

Metcalf Z.P. 1936. Part 2. Cixidae. In: Metcalf Z.P. (ed.) General Catalogue of the Homoptera, Fascicule $I V$ : 1-267. North Carolina State College, Raleigh, NC, USA.

Metcalf Z.P. 1938. The Fulgorina of Barro Colorado and other parts of Panama. Bulletin of the Museum of Comparative Zoology 82: 277-423.

Metcalf Z.P. 1947. The center of the origin. Journal of the Elisha Mitchell Science Society 62: 149-175.

Metcalf Z.P. 1952. New names in the Homoptera. Journal of the Washington Academy of Sciences 42 (7): 226-231. 
Metcalf Z.P. 1956. Part 18. Eurybrachidae and Gengidae. In: Metcalf Z.P. (ed.) General Catalogue of the Homoptera. Fascicle IV, Fulgoroidea. North Carolina State College, Raleigh, NC, USA.

Muir F. 1923. On the classification of the Fulgoroidea (Homoptera). Proceedings of the Hawaiian Entomological Society 5: 205-247.

Muir F. 1925. On the genera of Cixiidae, Meenoplidae and Kinnaridae. Pan-Pacific Entomologist 1: 97-110, 156-163.

Schaum H.R. 1850. Fulgorellae. Erste Section A-G. In: Ersch I.S. \& Gruber I.G. (eds) Allgemeine Encyklopädie der Wissenschaften und Künste in alphabetischer Folge von genannten Schriftstellern bearbeitet und herausgegeben 51: 58-73. Johann Friedrich Glebitsch, Leipzig.

Schmidt E. 1908. Beitrag zur Kenntnis der Eurybrachinen (Hemiptera - Homoptera). Zoologischer Anzeiger 33: 241-247.

Shorthouse D.P. 2010. SimpleMappr, an Online Tool to Produce Publication-Quality Point Maps. Available from http://www.simplemappr.net [accessed 13 Dec. 2017].

Signoret V. 1850. Notice sur le groupe des eurymélides. Annales de la Société entomologique de France, Série 2 8: 497-513.

Signoret V. 1858. Rectifications synonymiques relatives à divers Hémiptères. Bulletin de la Société entomologique de France, Série 3 6: xxxii.

Available from http://biodiversitylibrary.org/page/8375865 [accessed 23 Sep. 2018].

Soulier-Perkins A. 1997. Systématique phylogénétique et test d'hypothèses biogéographiques chez les Lophopidae (Homoptera, Fulgoromorpha). PhD Thesis. Muséum national d'Histoire naturelle, Paris.

Soulier-Perkins A. \& Bourgoin T. 1998. Copulatory mechanisms and sexual selection in the Lophopidae (Hemiptera: Fulgoromorpha). Annales de la Société entomologique de France, N.S. 34 (2): 149-162.

Stål C. 1859. Hemiptera. Species novas descripsit. Fregatten Eugenies Resa. Arkiv för Zoologi 4: 219298.

Stål C. 1861. Nova methodus familias quasdam hemipterorum disponendi genera. Öfversigt af Kongliga Svenska Vetenskaps-Akademiens Förhandlingar 18: 195-212.

Available from https://www.biodiversitylibrary.org/page/15376759 [accessed 23 Sep. 2018].

Stål C. 1862. Synonymiska och systematiska anteckningar öfver Hemiptera. Öfversigt af Kongliga Svenska Vetenskaps-Akademiens Förhandlingar 19: 479-504.

Available from https://www.biodiversitylibrary.org/page/15376267 [accessed 23 Sep. 2018].

Stål C. 1863. Beitrag zur Kenntnis der Fulgoriden. Entomologische Zeitung, herausgegeben von dem entomologischen Vereine zu Stettin 24: 230-251.

Available from https://www.biodiversitylibrary.org/page/35950043 [accessed 23 Sep. 2018].

Turton W. 1806. A General System of Nature, through the Three Grand Kingdoms of Animals, Vegetables, and Minerals, Systematically Divided into their Several Classes, Orders, Genera, Species, and Varieties, with their Habitations, Manners, Economy, Structure and Peculiarities. Lackington, Allen and Co., Temple of the Muses, London. https://doi.org/10.5962/bhl.title.37018

Walker F. 1851. List of the Specimens of Homopterous Insects in the Collection of the British Museum 2: 261-636. Trustees of the British Museum, London.

Available from https://www.biodiversitylibrary.org/page/9620260 [accessed 23 Sep. 2018].

Walker F. 1852. List of the Specimens of Homopterous Insects in the Collection of the British Museum, Supplement 4: 1119-1188. Trustees of the British Museum, London.

Available from https://www.biodiversitylibrary.org/page/9692970 [accessed 23 Sep. 2018]. 
Walker F. 1858. Supplement. List of the Homopterous Insects in the Collections of the British Museum 1-307. Trustees of the British Museum, London.

Available from https://www.biodiversitylibrary.org/item/79419 [accessed 23 Sep. 2018].

Manuscript received: 29 January 2018

Manuscript accepted: 20 August 2018

Published on: 13 December 2018

Topic editor: Gavin Broad

Section editor: Anna Namyatova

Desk editor: Danny Eibye-Jacobsen

Printed versions of all papers are also deposited in the libraries of the institutes that are members of the EJT consortium: Muséum national d'Histoire naturelle, Paris, France; Meise Botanic Garden, Belgium; Royal Museum for Central Africa, Tervuren, Belgium; Natural History Museum, London, United Kingdom; Royal Belgian Institute of Natural Sciences, Brussels, Belgium; Natural History Museum of Denmark, Copenhagen, Denmark; Naturalis Biodiversity Center, Leiden, the Netherlands; Museo Nacional de Ciencias Naturales-CSIC, Madrid, Spain; Real Jardín Botánico de Madrid CSIC, Spain; Zoological Research Museum Alexander Koenig, Bonn, Germany. 